Structure of a Story-Telling Performance Among
Carpatho-Rusyns in Zakarpats'ka Oblast' of Ukraine

\title{
ARTICLES
}

\section{Structure of a Story-Telling Performance Among Carpatho-Rusyns in Zakarpats'ka Oblast' of Ukraine: A Case Study}

\author{
Elena Boudovskaia \\ Georgetown University \\ Washington, D.C., USA
}

\begin{abstract}
This article analyses the transcript of the story-telling session with two participants, an 89-year-old woman and a 54-year-old man, that I audio-recorded in August of 2014 in the village of Novoselytsia in the Transcarpathian region of Ukraine. Although Western Ukrainian and Rusyn folk stories have been extensively collected since 1880-s (Hnatiuk 1897, 1898, 1900, Rozdol's'kyi 1899,1900 , etc.), entire story-telling sessions in these region have not been studied. My transcript reflects certain features of story-telling performance's macro- and micro-structure that either do not get recorded or get edited out in publications of folk texts, such as interaction between participants, discourse markers for organizing performance, repetitions, and digressions into everyday reality. After analyzing these features using Hymes' approach to linguistic and discourse markers in folk performance, I foreground the precise mechanism through which the collective creation of folklore [Jakobson and Bogatyrev 1980 [1929]] takes place.
\end{abstract}

\section{Introduction}

In the summer of 2014 in Novoselytsia I was fortunate to have the opportunity to record approximately an hour-long story performance: an 89-yearold woman and her 54-year-old adopted son were telling me stories that dido 'old man', the woman's late husband, used to tell. I transcribed the entire story-telling session, which consisted of twenty-one stories and the remarks during and between stories. The stories are listed below; the complete transcript may be found in the Appendix to this article.

At first glance, the transcript of the recording appears awkward. Each storyteller uses a lot of repetitions, repairs, and filler words; participants interrupt each other, add some details, argue about others, and remember things after the story is finished. However, all these features are important because they capture the story-telling session I witnessed and participated in. They are essential for analyzing this session as performance, which is the goal of this article. I argue that these corrections, interruptions, and discussions, usually omitted from publications of folk texts, are in the performance for a reason; they are pivotal in establishing the two-way connection between participants, which in its turn shapes the performed piece. Jakobson and Bogatyrev [1980 [1929]] defined 
folklore as a collective creation, and it has been one of central ideas in folkloristics for almost a century, but the exact mechanism of collective creation needs studying in the context of each tradition. My research starts to fill this gap for the Rusyn story-telling.

The approach to folklore as performance is also part of the mainstream in folkloristics today. There have been several approaches that stress the central role of performance in folklore. One approach views oral performance, analyzed from the point of view of language and discourse, as central for understanding the connection between verbal art, culture, and society, since performance constantly creates and re-creates tradition. (1) As Hymes put it, "in an oral tradition performance is a mode of existence and realization that is partly constitutive of what the tradition is" [1975: 19]. A great deal of research taking this approach has been done, mostly on Native American and other non-European cultures. (2) Another approach that emphasizes performance and its constitutive role in tradition is the oral theory, beginning with Parry and Lord's work on Homer and Yugoslav epics (3); this approach has largely been confined to the Slavic tradition, and focuses only on epic songs (see, e.g., the overview in Foley [1996a]), rather than on Slavic prose genres.

My basic goal was to study the features of the recorded performance and their functions. Following Hymes, I relied on a number of his methods. Working with the disappearing tradition of Chinookan narrative, Hymes distinguished between performance, which is the main, constitutive aspect of tradition, and other dimensions of folkloric knowledge that may exist even when the tradition of authoritative performance is no longer there. He noticed three dimensions of competence in a cultural tradition, namely, the ability to report, interpret, and perform a certain aspect of culture [Hymes 1975: $14 \mathrm{ff}$ ]. Hymes' insight that reporting and performance are different, though interconnected phenomena, has been corroborated in my material; for one, performance turned out to be more gender-specific than reporting and interpretation (both performers knew, and could discuss the meanings of, all the stories, but they had distinct preferences in telling them.) The reasons for this distinction merit further investigation. Second, Hymes paid special attention to linguistic features of performance, including its discourse features. Applied to the story-telling session in Novoselytsia, this attention to linguistic phenomena revealed that both the macro-level and microlevel in the performance contained a number of structural features that were mostly overlooked before. The reason why these phenomena largely remained invisible for folklore study was that they almost never made it into published texts. On the one hand, they were traditionally considered to be useless interruptions for the smooth flow of narration. In addition, before the advent of audio-recording technology, they were too difficult or even impossible to record. On the macrolevel, the phenomena I have observed in this session are: interruptions during performance, exchanges between participants (suggestions by listeners and acceptance or rejection of these suggestions by story-tellers, etc.); discussions before and after stories (negotiations of meaning and supplying additional details); and choice of a new story to tell. (4) On the micro-level, they include 


\section{Structure of a Story-Telling Performance Among Carpatho-Rusyns in Zakarpats'ka Oblast' of Ukraine}

certain types of discourse organizing devices: inversion of word order, connectors, and repetition. Other types of discourse devices used for organizing performance, namely, poetic formulae, have also been studied in epic poetry by the school of Lord and Parry. My material does not include poetic formulae per se; however, I show that certain devices present in my material, namely, connectors and repetition, play in prose story-telling a role which is similar to the role of formulae for poetic genres: both groups of phenomena organize performance for performers, giving them time to think, and for the audience, providing a feeling of suspense. Finally, I show that the features of performance present in my material on both the micro- and macro-level are pivotal to the shaping of stories during the process of interaction between story-teller(s) and their audience. This interaction is the precise mechanism of the collective creation, which is the essence of folklore according to Jakobson and Bogatyrev [1929].

I was especially interested in the following issues, which I will address in detail below after a discussion on the narrators' background and the performance context:

1 general organization of the performance on the macro-level: its parts, markers for specific parts, ways of linking parts together (e.g., what happens between one story and another);

2 techniques for participation of the two story-tellers; their roles, respective contributions, their interaction with each other and with me, their corrections and explanations;

3 how the text is generated (in the assumption that it is not all told from memory); what elements are used in its generation; how the text is organized on the micro-level;

4 ways of connecting the world of the stories with the present, and the status of stories for the tellers as truth;

Finally, I will consider the roles of these elements generally in the creation of the folk performance and/or text.

Background information

Novoselytsia

The village of Novoselytsia is situated at $48^{\circ} 41^{\prime} 59^{\prime \prime} \mathrm{N} 23^{\circ} 29^{\prime} 12^{\prime \prime} \mathrm{E}$, in the Zakarpats'ka oblast' (region), Mizhhir'ia district, in a mountainous area 475 meters above sea level. There are 1054 inhabitants in Novoselytsia according to the 2011 census. The Zakarpats'ka region was part of the Austro-Hungarian Empire, and then, between the wars, became part of Czechoslovakia, but Novoselytsia itself is only a couple of miles away from the mountain ridge separating the Zakarpats'ka region from the L'vivs'ka and Ivano-Frankivs'ka regions that once belonged to Poland. These historical borders are still remembered; in Novoselytsia people often referred to the linguistically and 
culturally similar population of the neighboring villages of L'vivs'ka and IvanoFrankivs'ka regions as poliaky (Poles).

The climate in Novoselytsia is moderate, but the winter is long, about 5.5 months, and snowy. The main crop that can be cultivated in this climate is potato; also important are cabbage, cucumbers, onions, beets, and several types of beans; before WWII, people also used to grow oats for bread. Much of the land is used for mowing grass for hay. Most inhabitants practice traditional agriculture: they have gardens, and keep cows, pigs, and chickens; some also keep sheep or goats that are herded in the mountain meadows in summer. There are not many jobs available, and people mostly survive off their land. In order to earn money, men may go to other countries to work as builders; women can earn money by gathering blueberries in summer for sale. There are two schools in the village, an elementary school (4 grades) and a high school (11 grades).

Fieldwork and language

I came to Novoselytsia several times between 1986 and 1992, recording texts and collecting information on the dialect. In 2010 during the expedition financed by a Collaborative Research Project Grant from NEH to study dialects and folklore of Transcarpathia and adjacent regions, I visited Novoselytsia again for a one-day pilot study. Since that time, I have travelled to Novoselytsia several times, recording dialectal texts, mostly from women, and from some men, in their 70 s and 80 s. (5)

The language my informants speak between themselves and the one I address them in is Rusyn. Rusyn is an idiom with a number of regional varieties; in Slovakia and Serbia, it is viewed as a minority Slavic language, and in Ukraine as a dialect of Ukrainian; for more detailed treatment see, Pugh [2009: vii-20]. My field materials, on which the article is based, reflect the variety spoken in Novoselytsia, which may vary from other types of Rusyn.

Informants, recording session, and its results

The recorded story-telling session took place in August of 2014 in Novoselytsia. My informants were: HK, female, 89 years old, illiterate, and her adopted son, IS, 54 years old, high school graduate. The family's brief history is as follows: HK was born in Pryslip, the neighboring village, in 1925; she married a man from Novoselytsia and moved there in the 1940s. They had one son who died in 1970; after that they adopted their remote relative, IS, who was in the $9^{\text {th }}$ grade. The goal of adoption was to have a person who could help them work, take care of them in their old age, and inherit their house and land after they were gone. Later IS got married and lived in the couple's house with his wife, LS. His children are now college students and have moved away. IS performs the functions of a reader in the local church; he is respected as a teetotaler.

HK's husband died several years ago, leaving his wife, adopted son and daughter-in-law (around 50 years of age) in the house. Their interaction is friendly and respectful. IS and LS do work in the house and in the field on behalf of HK; 


\section{Structure of a Story-Telling Performance Among Carpatho-Rusyns in Zakarpats'ka Oblast' of Ukraine}

she is still active and participates in household tasks; they ask her not to strain herself, but she states she cannot 'sit around doing nothing.'

The interaction took place in HK's house. I was brought in and introduced by the principal of Novoselytsia high school; he began with the standard introductory words that I was from America and had been coming to Novoselytsia for a number of years because I was interested in 'how people lived in olden times.' I indicated my wish to talk with HK because she was the oldest person in the household and I wanted to record what the members of the older generation remembered. Having received HK's oral consent for recording and using materials for possible publication in America, I started asking her open-ended questions about household practices in the times past (e.g., How did you spin and weave? How did you do laundry? How did you bake bread? etc.). I turned the recorder on at the beginning of the session and left it on for the entire conversation. HK was interested and talked with enthusiasm for about an hour; sometimes I would ask her for explanations or switch the topic, if she was silent for a while. I asked HK first about weaving and flax and hemp-working techniques and then about Christmas rituals. At some point IS joined us; I repeated that I wanted to record the elder generation. He was very understanding and did not volunteer much information, though he listened with great interest. Generally, I discourage members of the younger generation from participating because elderly people sometimes feel embarrassed that they do not 'speak the proper language,' especially when the younger generation starts to correct their speech offering nondialectal, 'city,' or literary Ukrainian forms instead. However, IS was speaking the village dialect to his adoptive mother, and she did not change her manner or speaking habits when he joined us. IS reminded HK if she forgot certain details, but other details were unknown to him, and he was interested in what HK was saying.

After about twenty more minutes, HK and IS started discussing village events that had a supernatural twist, i.e., how and why a certain woman got struck by lightning, and from there they switched to other folk stories of various genres. I did not interrupt them, and they were talking for quite some time. Then I started asking whether they heard such and such a story, suggesting plots I had heard in other Carpathian villages; they most often had not heard these stories, but remembered other stories similar in some respect, and then they added even more stories. Apparently, HK was more of authority in weaving and even in Christmas rituals than she was in stories, where she accepted IS's suggestions more often than not. HK and IS mentioned that some of these stories were the ones dido ('the old man,' i.e., the deceased husband of HK and adoptive father of IS) used to tell. They repeated several times what a good story-teller he was and what a pity it was I had not met him. The whole story-telling session lasted for approximately fortyfive minutes; at that point IS stepped out, and HK continued talking and answering my questions for about fifteen more minutes. Then she invited me to have a meal with them, and I turned off the recorder. However, in the course of the meal HK or IS sometimes remembered another story; then I would turn on the recorder again, record the story, and then turn it off till the next story. In such a way I 
recorded an additional 12 minutes of story-telling. Altogether I recorded twentyone stories, including an account of the death of HK's own son and the two dreams she had in this connection.

Story content

A brief summary of the plots of their stories is in the chart below. An entire transcript of the stories may be found in the Appendix:

\begin{tabular}{|l|l|l|l|l|l|}
\hline$\#$ & \multicolumn{1}{|c|}{ Content } & $\begin{array}{c}\text { Place in } \\
\text { recording }\end{array}$ & Teller & $\begin{array}{c}\text { Whoges } \\
\text { ted }\end{array}$ & Genre \\
\hline$\# 1$ & $\begin{array}{l}\text { a woman in the village says she } \\
\text { is not afraid of lightning and } \\
\text { then she is struck by lightning }\end{array}$ & $\begin{array}{l}21-1: 04- \\
21-1: 06(6)\end{array}$ & HK & HK & memorate \\
\hline$\# 2$ & $\begin{array}{l}\text { three pregnant women receive } \\
\text { prophecies about their } \\
\text { children's future deaths; all } \\
\text { three children die exactly the } \\
\text { way it was predicted }\end{array}$ & $\begin{array}{l}21-1: 06- \\
21-1: 10\end{array}$ & HK & IS & $\begin{array}{l}\text { religious } \\
\text { legend }\end{array}$ \\
\hline$\# 3$ & $\begin{array}{l}\text { a young woman wants to go to } \\
\text { church but cannot do so } \\
\text { because no one can sit with her } \\
\text { baby; when an unknown old } \\
\text { man (an angel) lets her go, she } \\
\text { sees a full church and hears a } \\
\text { beautiful sermon; when she } \\
\text { comes home, the old man tells } \\
\text { her there were only three } \\
\text { people in the church, and the } \\
\text { priest was driving bricks; when } \\
\text { she asks the priest, it turned out } \\
\text { he was really thinking about } \\
\text { building his house and not } \\
\text { about the sermon }\end{array}$ & $21-1: 14$ & HK & IS & $\begin{array}{l}\text { religious } \\
\text { legend }\end{array}$ \\
$\begin{array}{l}\text { a soldier is going home, asks to } \\
\text { sleep in a certain house, in this } \\
\text { house a woman gives birth and } \\
\text { the soldier hears someone } \\
\text { prophesy that the newborn girl } \\
\text { will be this soldier's wife; the } \\
\text { soldier puts a girl on a stick in } \\
\text { the fence and leaves; years later }\end{array}$ & $21-1: 21$ & HK & IS & $\begin{array}{l}\text { tale of fate } \\
\text { akin to } \\
\text { ATU 930 }\end{array}$ \\
\hline
\end{tabular}


Structure of a Story-Telling Performance Among

Carpatho-Rusyns in Zakarpats'ka Oblast' of Ukraine

\begin{tabular}{|c|c|c|c|c|c|}
\hline \# & Content & $\begin{array}{l}\text { Place in } \\
\text { recording }\end{array}$ & Teller & $\begin{array}{l}\text { Who } \\
\text { sugges } \\
\text { ted }\end{array}$ & Genre \\
\hline & $\begin{array}{l}\text { he marries that very girl and } \\
\text { then recognizes her by the scar }\end{array}$ & & & & \\
\hline$\# 5$ & $\begin{array}{l}\text { a student is going home, an old } \\
\text { man in an oxcart gives him a } \\
\text { ride, when they are in the } \\
\text { middle of a river the old man } \\
\text { tells the student to get off the } \\
\text { cart; then the student stays for a } \\
\text { night at the old men's house, } \\
\text { steals the fried goose from the } \\
\text { oven and leaves old shoes in } \\
\text { the oven instead }\end{array}$ & $\begin{array}{l}21-1: 21- \\
21-1: 27\end{array}$ & $\begin{array}{l}\text { HK, } \\
\text { IS }\end{array}$ & HK & anecdote \\
\hline$\# 6$ & $\begin{array}{l}\text { St. Peter expresses a wish to be } \\
\text { God, and has to herd geese for } \\
\text { the whole day }\end{array}$ & $\begin{array}{l}21-1: 27- \\
21-1: 29\end{array}$ & HK & HK & $\begin{array}{l}\text { religious } \\
\text { legend / } \\
\text { jest } \\
\text { ATU } \\
774 D\end{array}$ \\
\hline$\# 7$ & $\begin{array}{l}\text { St. Peter and Jesus encounter a } \\
\text { lazy young man and a hard- } \\
\text { working girl, and Jesus says } \\
\text { this man will marry this girl } \\
\text { because this way they will both } \\
\text { survive }\end{array}$ & $\begin{array}{l}21-1: 29- \\
21-1: 30\end{array}$ & $\mathrm{HK}$ & IS & $\begin{array}{l}\text { religious } \\
\text { legend } \\
\text { ATU } 822\end{array}$ \\
\hline$\# 8$ & $\begin{array}{l}\text { St. Peter and Jesus stay for the } \\
\text { night at the house of a man and } \\
\text { his wife who is drinking hard, } \\
\text { and she beats St. Peter twice }\end{array}$ & $\begin{array}{l}21-1: 30- \\
21-1: 34\end{array}$ & HK & IS & $\begin{array}{l}\text { religious } \\
\text { legend / } \\
\text { jest } \\
\text { ATU } 791\end{array}$ \\
\hline$\# 9$ & $\begin{array}{l}\text { a Roma outwits a priest: first } \\
\text { the Roma says he killed a } \\
\text { rabbit by shooting it with a hoe, } \\
\text { and then they have a dream- } \\
\text { telling contest where the Roma } \\
\text { cheats the priest out of the } \\
\text { rabbit }\end{array}$ & $\begin{array}{l}21-1: 34- \\
21-1: 37\end{array}$ & IS & IS & anecdote \\
\hline$\# 10$ & $\begin{array}{l}\text { a monk in a monastery } \\
\text { exorcises a devil out of a } \\
\text { person }\end{array}$ & $\begin{array}{l}21-1: 38- \\
21-1: 40\end{array}$ & $\begin{array}{l}\text { HK, } \\
\text { IS }\end{array}$ & & memorate \\
\hline$\# 11$ & $\begin{array}{l}\text { a person from a village makes a } \\
\text { thief who stole his harrow } \\
\text { bring the harrow back to him }\end{array}$ & $\begin{array}{l}21-1: 41- \\
21-1: 42\end{array}$ & IS & $?$ & memorate \\
\hline
\end{tabular}




\begin{tabular}{|c|c|c|c|c|c|}
\hline \# & Content & $\begin{array}{l}\text { Place in } \\
\text { recording }\end{array}$ & Teller & $\begin{array}{l}\text { Who } \\
\text { sugges } \\
\text { ted }\end{array}$ & Genre \\
\hline$\# 12$ & $\begin{array}{l}\text { a man is going by cart; when he } \\
\text { passed a building site the } \\
\text { builders magically stop his } \\
\text { horses; he makes horses go } \\
\text { again and makes one of the } \\
\text { builders hurt himself }\end{array}$ & $\begin{array}{l}\text { 21-1:42- } \\
21-1: 46\end{array}$ & HK & HK & memorate \\
\hline$\# 13$ & $\begin{array}{l}\text { a woman in the neighboring } \\
\text { village magically stops a tractor } \\
\text { that trespassed on her land }\end{array}$ & $\begin{array}{l}21-1: 46- \\
21-1: 47\end{array}$ & IS & IS & memorate \\
\hline$\# 14$ & $\begin{array}{l}\text { certain tree in the forest is } \\
\text { destined to kill a person }\end{array}$ & $\begin{array}{l}21-1: 50- \\
21-1: 51\end{array}$ & HK & IS & $\begin{array}{l}\text { belief? } \\
\text { memorate } \\
\text { ? }\end{array}$ \\
\hline$\# 15$ & $\begin{array}{l}\text { a man gets lost in the woods } \\
\text { because he went to the woods } \\
\text { on Sunday; he only can find the } \\
\text { way when he makes the sign of } \\
\text { the cross }\end{array}$ & $21-1: 52$ & HK & & memorate \\
\hline$\# 16$ & $\begin{array}{l}\text { three girls are going across the } \\
\text { rail track before a train but are } \\
\text { not killed; devil says he cannot } \\
\text { harm them because they are } \\
\text { protected by the sign of the } \\
\text { cross or by prayer }\end{array}$ & $\begin{array}{l}21-1: 53- \\
21-1: 54\end{array}$ & HK & & $\begin{array}{l}\text { religious } \\
\text { legend }\end{array}$ \\
\hline$\# 17$ & $\begin{array}{l}\text { in a place where a person got } \\
\text { killed by a tree there is a voice } \\
\text { that says 'watch out, watch out' }\end{array}$ & $21-1: 56$ & HK & & belief? \\
\hline$\# 18$ & $\begin{array}{l}\text { how the speaker's son died and } \\
\text { what two dreams she saw in } \\
\text { this connection }\end{array}$ & $\begin{array}{l}21-1: 58- \\
21-2: 05\end{array}$ & HK & & $\begin{array}{l}\text { personal } \\
\text { experienc } \\
\text { e tale; } \\
\text { memorate }\end{array}$ \\
\hline$\# 19$ & $\begin{array}{l}\text { Roma outwit a rich landowner } \\
\text { who wanted to know how they } \\
\text { earned their living, and cheat } \\
\text { him out of his two horses }\end{array}$ & $\begin{array}{l}22-00-22- \\
02\end{array}$ & HK & $?$ & anecdote \\
\hline$\# 20$ & $\begin{array}{l}\text { 'don't pity an orphan, don't tell } \\
\text { the truth to your wife, don't let } \\
\text { a rich landowner borrow your } \\
\text { money' }\end{array}$ & $\begin{array}{l}22-03-22- \\
07\end{array}$ & $\begin{array}{l}\mathrm{HK}, \\
\text { IS }\end{array}$ & HK & $\begin{array}{l}\text { realistic } \\
\text { tale, akin } \\
\text { to ATU } \\
893 \text { The } \\
\text { Unreliabl } \\
\text { e Friends } \\
\text { and ATU }\end{array}$ \\
\hline
\end{tabular}


Carpatho-Rusyns in Zakarpats'ka Oblast' of Ukraine

\begin{tabular}{|c|l|l|l|l|l|}
\hline$\#$ & Content & $\begin{array}{c}\text { Place in } \\
\text { recording }\end{array}$ & Teller & $\begin{array}{c}\text { Who } \\
\text { sugges } \\
\text { ted }\end{array}$ & \multicolumn{1}{|c|}{ Genre } \\
\hline$\# 21$ & $\begin{array}{l}\text { devil introduces hard liquor, } \\
\text { makes a man beat his wife, and } \\
\text { makes people behave like } \\
\text { foxes, like wolves, and like } \\
\text { pigs }\end{array}$ & 12 & $\begin{array}{l}22-07-22- \\
\text { Good } \\
\text { Precepts }\end{array}$ \\
\hline
\end{tabular}

Organization of the performance on the macro-level

The performance I attended was different from what a regular performance would be like, first and foremost because I was (in) the audience. My initial request to hear "about the old life" was an artificial occasion, and I was an unusual listener. I also wanted to listen mostly to HK, which could have influenced the distribution of roles in performing. On the other hand, this performance was closer to a regular performance than to a one-on-one recording session in the sense that there were two performers, who were not only bearers of the same culture, but members of the same household, apparently with experience of participating in similar events in their family circle. They seemed to incorporate me in their event, not worried by, but alert to, my presence. This alertness mostly showed in their being extra helpful, explaining meanings of words and realia to me, a stranger $(1: 12,1: 14,1: 16$, etc.). There seemed to be more of such explanations than there would be, for example, at a session including a younger family member. Otherwise, it felt like a normal and successful performance, in the sense that both performers seemed to have a good time telling stories to a new audience, as good performers usually do.

The general pattern of the session was as follows: one person would remember and suggest a story, then s/he or the other person would tell it, while the one who was not telling would listen and comment. The comments were usually short, from a couple of words to a short sentence, but numerous, up to 67 comments during a 5-minute long story. The commentator would either explain what was going on (IS: "She did not have anyone to leave a baby with," 1:11) or anticipate what was going to happen (HK: "And off he went," 1:22). The teller would mostly agree with the comments and continue with the story. When the story was over, the participants would discuss it, repeating key moments from the story, explaining the characters' motivation and commenting on the general meaning of the story (e.g., see the discussions at the end of \#1 at 1:05, or \#4 at $1: 21$, or \#19 at 02 in the appendix). This discussion would last for some time until one of the tellers suggested another story. 
Differences in the story-telling of HK and IS

The two performers each had a distinct part in the telling. HK told the most stories. Her stories were intricate and captivating, though her memory, probably due to her age, was at times faulty: while telling, she sometimes said she was not sure of a detail $(1: 07,1: 09,1: 16,1: 20,1: 43,1: 46$, etc.), or she would forget something and add it as an afterthought (1:09), or IS would add it for her (1:18). She also was the only one to add a long digression to one of her stories (how she used to go on foot to the nearest town 1:15). When IS was telling a story, HK would comment from time to time, mostly to suggest a word (1:24), to anticipate a narrated event (1:22), or just to agree $(1: 22)$.

HK told three times as many stories (18 stories out of 21, 3 of them together with IS, 15 independently, while IS told 6 stories, 3 of them with HK, 3 by himself). However, IS was also able to tell stories, which he did a couple of times when he thought HK was wrong or when she did not remember the plot (1:22 the story of the student, 03 - 'don't tell secrets to your wife'). In terms of number of words, HK said only a little more than twice as many words as IS (HK - 6683 words, IS - 2687 words). That is, IS was true to his word and let HK tell more stories, but at the same time he himself was talking a lot. On the one hand, his stories, though fewer, tended to be long and elaborate, containing a number of episodes each, as well as a lot of detail and dialogue $(\# 5,9,20)$. On the other hand, he gave a lot of commentary and explanations on a number of topics, from explanations of words and realia $(1: 12$, etc.) to commentaries on the plot and the characters' motivations $(1: 13,1: 14$, etc.). He often rephrased something that had been already said, or added a detail. He also corrected HK if he felt she was mistaken (1:22). He also often remembered a new story and suggested that HK tell it (stories \#2, 3, 4, 7, 8, 14, possibly 21).

The difference between the styles of the two performers seems to stem from their attitude to the stories and, generally, to the tradition. HK was inside the tradition; she did not perceive story as object (7); for her, the performance and the story were fused. She did not think I might need explanations on the story during performance and only rarely provided spontaneous translations (1:12). IS was more conscious of story as object, and of the possibility that I, a stranger, would not understand it, so he was providing report and interpretation during the telling. (8) In addition, IS apparently felt in charge not only for the text, but also for the performance. When he did not know something HK knew, he urged her to tell about it (1:47, about the tree killing a person). Several times when she forgot a detail he perceived as important, he jumped in and supplied it (1:12 - about the angel seeing only the three people who prayed devoutly as the ones really present in the church; 1:18 - about the soldier rejecting the idea that the girl he saw being born would become his wife, etc.) On several occasions he thought of a story and reminded $\mathrm{HK}$ of it, so that she could tell it. However, besides organizing the performance, he also could perform (in Hymes' terms), and was just as good a story-teller as HK was. 


\section{Structure of a Story-Telling Performance Among Carpatho-Rusyns in Zakarpats'ka Oblast' of Ukraine}

There also seemed to be a difference between the genres of stories each person preferred to tell. The stories include: memorates (in which I also include the stories told by 'friend of a friend', i.e., \#\# 1, 10, 11, 12, 13, 15), religious legends and tales of fate (\#\#3, 4, 6, 7, 8, 16, 20, 21), and anecdotes (\#\#5, 9, 19, 20). Among the six memorates, most were, expectedly, told by HK (told 4, suggested 2). IS told, or participated in telling, three memorates, and suggested only one. However, the two memorates he told on his own (\#\#11 and 13) are short and not as impressive as, for example, a well-developed \#12, suggested and told by HK. The overall impression is that memorates were not IS's favorite genre.

\begin{tabular}{lll}
\multicolumn{2}{l}{ Memorates } \\
\# Teller & Who Suggested \\
1 HK & HK & \\
10 & HK, IS & \\
11 & IS & $?$ \\
12 & HK & HK \\
13 & IS & IS \\
15 & HK &
\end{tabular}

Out of eight religious legends and tales of fate, HK told eight and suggested two; IS told one (together with HK) and suggested five. Again, HK was the main teller. IS often suggested a tale, but rarely told it himself (maybe because I had said I wanted HK to talk). However, he seemed to know them all, and if HK forgot something, IS was eager to step in (\#20).

\begin{tabular}{|c|c|}
\hline Religiou & Legends, Tales \\
\hline \# Teller & Who Suggested \\
\hline $3 \mathrm{HK}$ & IS \\
\hline $4 \mathrm{HK}$ & IS \\
\hline $6 \mathrm{HK}$ & $\mathrm{HK}$ \\
\hline $7 \mathrm{HK}$ & IS \\
\hline $8 \mathrm{HK}$ & IS \\
\hline 16 & $\mathrm{HK}$ \\
\hline 20 & HK, IS HK \\
\hline 21 & HK IS? \\
\hline
\end{tabular}

In anecdotes and non-religious legends, IS was more often a teller than in other story types: he told three stories out of four (two of them with HK), and suggested one, while HK told three (two of them with IS), and suggested two. Though HK may have suggested an anecdote and start telling it, IS just could not help himself because he was sure he knew the story better and could tell it better (as in \#5). With stories of other types, according to my request, IS tried to let HK tell as many stories as she remembered, but with anecdotes, more often than with other types of stories, IS told the stories himself. 


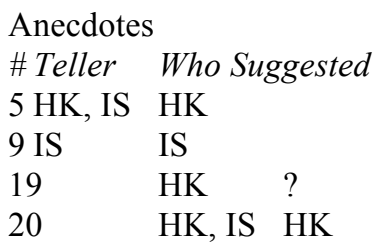

Thus, the recorded storytelling session showed a difference between male and female roles in storytelling performance, if not in the knowledge of the stories of various genres. IS knew all three types of stories, i.e., memorates, religious legends, and anecdotes, but he preferred to tell anecdotes. My impression was that he was not particularly interested in memorates. However, he vividly discussed one memorate (\#12), possibly because he knew and trusted the person (dido) who used to tell it. HK knew and told all three types of stories, but memorates and religious legends seemed to be more to her taste.

Thus, we can hypothesize that anecdotes are more of a men's domain, while religious legends and memorates are women's. This contention is supported by previous research as well; see, Dégh [1999: 582] noticing that in contemporary story-telling, "[d]evelopment of genre specialization may be observed between the sexes: the märchen and the ghost stories became almost exclusively feminine, whereas men became the tellers of jokes, lies, and humorous and adventurous occupational and personal narratives," or Kiliánová [1999:104] stating that among her informants in rural Slovakia in 1981-83, "the best narrators of anecdotes from the society's point of view (and also my own view) were men... while the best performer of magic tales and ghost stories was a woman." Moreover, Dégh [1989: 159] observed during her fieldwork in the Hungarian village of Kakasd in the 1940s-50s, that religious legends "were especially favored by [...] women." Thus, the fact suggested in literature that men are more prone to telling certain types of stories (i.e., anecdotes), and women, others (i.e., religious legends), is supported by the recording session in Novoselytsia. What is significant is that it while performance is gender-specific, knowledge of the stories is not. Both IS and HK were equally familiar with narratives of all three genres.

Organization of the performance on the micro-level

Both HK and IS followed particular patterns when telling a story. First, they suggested a story: they referred to it either by a plot summary (that happened more often with short, uncomplicated stories): "how one person was told that he would die from a tree, when a beam fell on him" (\#2), "how St. Peter was herding geese" (\#6), "how a woman beat St. Peter" (\#8), "a woman stopped tractors" (\#13), "where moonshine came from" (\#21), etc., or by using the initial, expository portion: "how that woman wanted to go to church" (\#3), "how a soldier was returning from the army" (\#4), "how a student crossed a river" (\#5), "how that guy was lying under a pear-tree when they were passing by" (\#7), or, less frequently, by a punch line: "when God permits, a hoe fires" (\#9), "don't pity an 


\section{Structure of a Story-Telling Performance Among Carpatho-Rusyns in Zakarpats'ka Oblast' of Ukraine}

orphan, don't tell the truth to your wife, don't lend money to a nobleman" (\#20). The majority of such references were relative clauses beginning with the word "how." They may not be titles in strict sense. Since some of them include deictic elements ("that woman", "that guy"), they might be occasional descriptions rather than fixed titles for these specific stories, and might have only a mnemonic function. (9)

Stories usually started with a sentence where a subject and predicate were in the reversed order, i.e., predicate (underlined in the examples below) - subject (bolded): \#1: HK | сиді́ли три́ жо́ны | у канто́pi | 'Three women were sitting

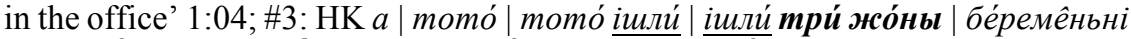

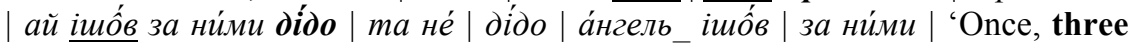
women were walking, three pregnant women, and behind them, an old man was walking. It was not an old man, but an angel, he walked after them' 1:06, etc. This word-order in the closely related Russian language "ha[s] long been associated with folklore, poeticity, and stylization [e.g. Adamec 1966, Kovtunova 1980]" [Yokoyama 1986: 284]. However, in the recording session, this word order occurred not only at the beginning of a story. It also marked the occasions when a new person was (re)introduced in the narration: | она́ бы іила́ до це́́рькви |i mýú захо́dum dído | до хb́жi 'And this one wants so much to go to church. And here an old man enters the house.' (1:11); она́ бь́ла пішла́ айбо діти́ну | а́йно ниє на ко́го лиши́ти | но $i$ захо́dumb дído| 'She wanted to go, but there was no one to leave the baby with. And so an old man comes in, ...' (1:11); | бо́ приємле

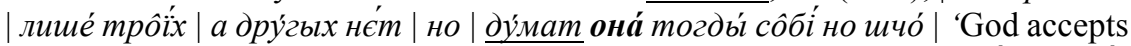
only three, but not others. Well, then she thinks to herself...' (1:13); dído nimốr ге́m | буде́ ôнá imú до попа́| бде́ каза́ти се попо́ви | 'The old man went away. She [decided] to go to the priest, will tell that to the priest...' (1:13), etc. Overall, this word order seems to be a device to shift the focus of the narration to a new person, whether it is at the beginning of the story or in its middle, rather than a specific device for starting a story.

In the text of each story one can detect a number of discourse markers with framing functions. (10) The expressions $a$ 'and', $i$ 'and', myй, mуйкbl 'here', yжé 'already', но 'well, and', а́йно 'yes, well' mark a beginning of a new episode (framing devices are underlined in the examples below). (11) They may be combined, as in быв | ішо̂́в із | сол... | із а́рміi солда́m $\mid$ i ти́йкы уже́ ся приме́́рькло ніч | 'a soldier was returning from the army, and it already became dark, the night started' (1:15; the English translation is not a word-by-word translation and does not always convey the clustering of markers), or: | $і$ каза́в |

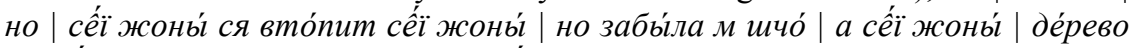
убъ 'є́ \а́йно this woman's [child] will drown, this woman's - I forgot what, and this woman's [child] will be killed by a tree. Yes. And then boys already grew up, they are growing' (1:07). The expressions тай нич / но і нич / но і всьо 'and that's it', 'nothing more happened', 'OK' usually close an episode and at the same time build suspense, making listeners anticipate what is coming: IC nín ду́мав шчо |

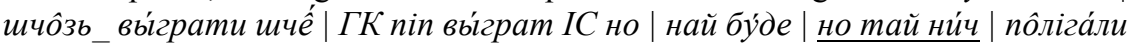


спа́ти спля́m $\mid$ а за́яць у печи́ | пече́ ся | ра́но пробуди́ли ся | IS: '... The priest thought he would win something. HK: That the priest would win. IS: Well, OK. OK. They went to sleep, they are sleeping, and the rabbit is in the oven, baking. In the morning they woke up...' (1:36). The words maŭ mák 'and that is it; and that is how it was' often served as an episode closing marker; sometimes they ended the whole story (1:14, 1:30, 2:05), but they also could end an episode (1:26, $08)$ or a digression within a story (1:15).

These markers indicating the opening and closing of an episode may appear to be mere fillers, but in fact they function similarly to formulae in oral poetry by giving the teller time to think, and, at the same time, creating suspense for listeners. Unlike the formulae in oral poetry, these markers do not have rhythmical structure, as one would expect in a prose genre, but they add both structure and suspense, allowing the listeners to detect what part of episode they are in, and at the same time holding them in anticipation about what content they are going to hear. (12) Another device that functions similarly to opening and closing markers is repetition, as in: | но тай ліга́ют спа́mи | тай по̂ліга́ли спа́ти тай| 'And they go to sleep. And they went to sleep' (1-24). The repetition is never exact, but repeating the word with slight variations in several sentences allows the storyteller to gain time to think, and slows the story down for the listeners, building suspense. (13)

In the recording session there were no specific folkloric formulae closing a story (of the type e.g., of the rhyming "I stepped on a rock, and that was the end of the story. I stepped on a stick, tell me if [what I told] was not right" as in Pan'kevych [1938:463]. Pan'kevych recorded this ending in a humorous personal experience tale; though generally such endings are known from fairy tales, it appeared in another type of story in this case. Theoretically an ending like this could have appeared in one of the stories in the session; however, it did not. It is not clear whether such endings are generally not typical for genres other than fairy tales (14), or have disappeared from the story-telling practices, or whether they are still in usage under specific circumstances, e.g. if the end of the story is also the end of a story-telling session, or whether some tellers use them while others do not.

After a story would end, the two participants would start a discussion, repeating the punchline if there was one, discussing the meaning of the story, its connection to everyday life ("So that's how it is now too" $1: 14$ ), returning to a specific episode of the story and repeating something from the text or adding what they had forgotten to say, and then again returning to the overall meaning of the story, tying the details with the main message. This commentary would take some time. Its point seems to be to keep the audience and the tellers in the story-telling mood; this mood lingers while the discussion is going on until someone thinks of another story to tell; if no one does, the session is over. My questions to the two story-tellers whether they knew of such and such story seemed to fall within the framework of a story-telling session; these questions helped the story-tellers remember a new story even though usually it was not the one I suggested. In my view, it was appropriate to suggest a story to HK and IS, since that was what they 


\section{Structure of a Story-Telling Performance Among Carpatho-Rusyns in Zakarpats'ka Oblast' of Ukraine}

did between themselves as well. I also asked questions about details of the previous story and that prompted them to expand on the explanations and, therefore, to stay in the story-telling mood. The only difference I could see between my and their discourse strategies is that I asked questions, while they did not; their suggestions, explanations and even questions would be in the form of a statement or a request. The general role of questions and statements in discourse in the dialect of Novoselytsia may be different from English (e.g., the normal way

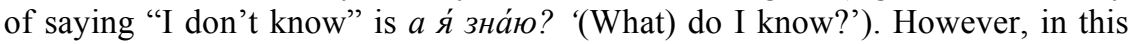
case, I think I have an understanding of HK and IS's usage of statements in form: even if they expressed their uncertainty about specific details, their statements might have indicated their knowledge of these stories, in terms of both meaning and context, while my questions indicated I was ignorant of the tradition and asking for assistance in a way.

In order to make clear how these elements operated in context, I will now provide an analysis of the transition from one story to the next on the micro-level. Below is a transition between stories \#18 and \#19, at 02, in English translation.

1. HK: [finishing the story] [...] The Roma got on the horse and says: now one pull [the coach], and the other, push it. And off he went, and never came back, this way he went to fetch the manta [deception]. They [the Roma] took both horses. And the coach remained, and the nobleman remained, and his coachman remained.

2. IS: The Roma got on the horse and says: fare you well...

3. HK: Yes, yes, fare you well...

4. IS: One person, pull it, the other, push it.

5. HK: And the other, push it. So that one would pull it, and the other, push from behind.

6. IS: That's the manta.

7. HK: Yes, that's the manta. And the Roma live from that manta. They deceive here and deceive there, and so they live from manta. Well, and also I remembered another story, and I think let it be here, so that you have it.

First, in (1), HK ends the story, then the (rhyming) punchline is repeated and corrected by IS $(2,4)$, and HK agrees $(3,5)$ and explains the meaning of the punchline (5). Then IS explains what the Roma's words mean (6), and HK agrees and explains the connection between the story and the real life (how Roma live from manta); in the meantime, she remembers another story to tell (7). When IS interrupts $\mathrm{HK}$, who is the story-teller at the moment, to add his own commentaries, he is not saying the whole thing at the time, but gives a short utterance (half of a punchline, or a short comment) every time, as if he is pondering what and how to say. HK approves of his words every time, and only then does IS go on with another detail. On the other hand, HK not only approves 
of IS's words, she then, true to her role as a teller of this story, expands and explains IS's words, as in (6) and (7), as if improvising on the theme given by IS. This exchange during which both participants, one as the story-teller, the other as the audience, are shaping the story together, seems characteristical not only for this story-telling performance, but for many others that I recorded in Novoselytsia.

True or False? Tellers' attitudes toward stories and techniques for connecting them to the real world

In the excerpt quoted above, one can see another feature that is common to many stories in this session. The explanation about the Roma living from manta connects the world of the story with the world of here-and-now, and thus validates the story's truthfulness. (15) The majority of stories have some type of anchoring device, though the exact means used to anchor them may vary depending on the genre of story.

We can summarize the anchors as follows. Typically, all the memorates contain personal and/or place names (Ivanycka; there was one Yurchak; the father of that Evka Diakova; somewhere in Volosianka, etc.) Religious legends and tales of fate often contain either: 1) ethnographic details (often in the form of digressions introduced by the explanation that "it used to be that way long ago", as in $\# 2$ - the digression about beams and chimneys and in \#3 - the digression about walking long distances); or, 2) the remark that "such things happen now too" (\#3 - nowadays people also get distracted in church, \#6 - nowadays geese also damage gardens, \#16 - nowadays one also needs to pray before going somewhere, \#21 - people also get drunk now). Anecdotes contain 1) one referral to some authoritative person who told the story (and that is why it is truthful) e.g., $\# 5$; or, 2) 'such things happen now too' - \#19 (as in religious legends).

Thus, the stories of near past are grounded in the world of here-and-now by mentioning real and familiar (at least to the performer) people and places. (16) The stories of olden times are connected with the present by referring to certain details from the story that still may be found in the present and are familiar to listeners (such as geese damaging gardens) or that have changed recently, but are still familiar to performers (such as walking long distances on foot before the time of cars and buses). While the first type of linking is a typical verisimilitudinal device, the mentioning of archaisms may serve to preserve "the long-ago setting of the tales." (17) The figure of a respected story-teller who used to know and tell the story also can be evoked to ground the story in the tradition and thus to confirm its truth.

The devices to connect two worlds, the one of the story and the one of the performance, thus are various and genre-specific. It did not seem, however, as if the tellers were using them to convince the listener of the reality of their artistic creation in which they did not believe themselves. On the contrary, based on their commentary, it was clear that the belief of the two tellers in the truthfulness of their stories was sincere, possibly absolute, regardless of the genre. In the course of the session, neither of the tellers said anything that could be understood as 


\section{Structure of a Story-Telling Performance Among Carpatho-Rusyns in Zakarpats'ka Oblast' of Ukraine}

doubt about the truthfulness of any story. The recording contains one instance of a statement about stories being true, when IS mentioned, after finishing an anecdote about a student outwitting a peasant: "That is not that someone made it up, it was like that. That is what our old man, blessed be his soul, used to tell" (1:27). During the discussions after the end of each story, the two tellers at times disagreed about details (e.g., when exactly the soldier married the girl that had been destined to become his wife or whether a new monk would make a good exorcist), but only once one of them doubted the truthfulness of the story, when, between the stories \#10 and \#11, the question arose whether the old man who said that thieves would bring him back stolen sacks really meant it, i.e., whether he had some powers to make it happen. Even in this case, the question was whether this man was bluffing in this particular case, not whether such things were possible; that was beyond doubt. HK was more often using a story as a source of teaching about right and wrong, as an instruction for living right, while IS was less moralizing and seemed to tell stories more for entertainment, but for both of them, the stories were true.

\section{Conclusion}

Until recently, recordings of entire performances of Slavic tales have been scarce. (18) For Rusyn, they have been nearly non-existent. Such recordings are an invaluable source for an analysis of the structure of folk narrative, which some researchers, beginning with Hymes, call ethnopoetic features, and others, namely Bauman, call keying of performance. This approach, in its turn, is important since "careful attention to linguistic details can reveal much about the poetics and aesthetics of the source-language versions" [Webster 2008a: 441]. Such analysis is a variant of the discourse-centered approach to language and culture developed by Sherzer [1987, 1990], Urban [1991], Webster [2008a]. Though particular discourse features of a folkloric performance can be recovered from a text dictated to a person who recorded it by hand ([Hymes 2003] and [Webster 2008a], etc.), a transcript of an audio performance can reveal much more. For example, although the majority of his stories are simply texts as dictated, Pan'kevych [1938] has also published a few transcripts of audio texts. These transcripts show an impressive number of details of narrative structure missing from dictated texts alone. One can appreciate the drastic difference in discourse devices between two stories, \#36, audio recorded from an informant born in a village from the Irshava district, and \#35, dictated by an informant from the same district: in the story transcribed from the audio recording, the word но 'well,' a sign of continuation of a narrative, occurs ten times in a text less than a page long, while in the dictated story, но does not occur even once in a narrative of more than two pages. This example shows that when recording by hand, important discourse elements can be considered unnecessary fillers even by thorough dialectologists such as Pan'kevych and will be omitted at the stage of narration. Conversely, faithful transcripts of audiorecorded texts allow us to preserve more elements that are vital to understanding narrative and performance. Even more information can be provided by transcripts 
of entire performances, including not only the stories, but also all the communication that takes place before, after, and between them, which, as far as I know, has not yet been done with Rusyn or Ukrainian material. Such sound recordings can be pivotal for understanding the overall organization of folkloric performance in the area. Published collections of folkloric texts from Western Ukraine and specifically Carpathian region, despite their abundance, may not provide necessary details for such research.

This article is the first attempt to analyze an instance of story-telling performance based on Rusyn material. Even though, as I mentioned, this performance cannot be considered totally typical since I was present in the quality of a listener, it allowed us to highlight several important factors about performance structure in Rusyn culture that merit further investigation. First, there is a definite structure to a story-telling session. Stories are suggested, and then told (not obligatorily by the one who suggested them). While they are told, other participants can suggest corrections, explanations, and anticipate the next move. When the story is over (there were no specific folkloric endings to stories in the recorded session), the story-teller and other participants usually discuss this story, adding details, teasing out the overall meaning of the story and its connection to their lives. During this discussion, another participant may remember another story and tell it or suggest it to another participant as a possible narrative for the session. If no one remembers another story, someone may suggest something else to do, and the story-telling will be over.

This discussion between the stories, as well as the interruptions by other participants during the story, seem to be the very instruments of the "collective creation," as well as of "preventive censure" that Jakobson and Bogatyrev mention as characteristic features of folklore [1980[1929]: 20 and passim]. These two forms of interaction during a story-telling session convey folk knowledge and the expectations of the entire audience to the current story-teller, and also allow for the collective negotiation of the meaning of the story. It is noteworthy that during the recorded story-telling session the current story-tellers agreed with, and incorporated in their stories, most of the suggestions by the other participant. This practice is thus a living example of how "collective creation" works.

The role of an individual performer in creating and maintaining the Rusyn folk tradition certainly needs more research, since our sample is limited. There were only two performers in the recorded session; their roles were different in one respect, and similar in other. However, we can make some preliminary conclusions: the gender and age of performers influenced their performance. The male story-teller seemed to be more prone to tell anecdotes (anecdotes), while the female story-teller preferred religious legends. However, both were similar in their living knowledge of tradition and the ability to perform a variety of genres. Both knew each other's repertoire in all genres, commented on each other's tales, and helped out when the other performer forgot certain details. The younger performer, IS, at 54 years of age, was as good a story-teller as his 89-year-old adoptive mother HK. Moreover, he felt responsible for the whole performance and tried to organize it as best he could, helping HK with details, but at the same 


\section{Structure of a Story-Telling Performance Among Carpatho-Rusyns in Zakarpats'ka Oblast' of Ukraine}

time complying with my request to let HK talk more. The overall impression was that the younger generation can maintain the story-telling tradition, not only in the sense of knowledge of tradition, but also in the sense of the ability to do an authoritative performance [Hymes 1975:69]. Thus, the traditional rural folklore in Novoselytsia continues to thrive, (19) at least in the generation which is now 50-60 years of age, even if the tradition for them is more "external" than for the elder generation, i.e., they are more likely to view the stories as objects, as we have seen. Moreover, the serious attitude towards tradition and the belief in the truth of the stories coming from a traditional source as demonstrated by IS ("That is not that someone made it up, it was like that. That is what our old man, blessed be his soul, used to tell") indicate that the tradition continues to have authority in this generation despite of many other influences. IS's respect to tradition is not diminished by the fact that he is also a high school graduate and an active member in the church. His sharing of a traditional worldview seems to be rooted in his rural lifestyle and daily communication with like-minded people. The demographic data on the Transcarpathian region show solid and growing rural population. (20) That suggests that the rural environment continues to provide an opportunity for traditional Rusyn folklore to live and develop.

On the micro-level, a performed story includes a number of linguistic markers indicating the beginning or an end of an episode and the introduction of a new person. These markers seem to orientate listeners within an episode. They also seem to build suspense, as well as give the speaker time to think of what to say next; that is, they perform a similar function to what formulae do in epic genres of folklore. However, in prose stories they do not carry the function of maintaining the required rhythm. Building suspense and giving the speaker time seems also to be the function of repetition of words and phrases, similar to its function in poetic folklore genres. Stories and participants' comments also contain a number of verisimilitudinous devices connecting the world of story and the world of story-tellers and their audience, either through digressions about details that are similar in both worlds or by referring to the authority of tradition. Thus, the micro-structure of a story-telling performance, same as its macro-structure, abounds in devices that may seem to interfere with the smoothness of narration (and that is why they are usually omitted when stories are dictated or edited for publication), but are absolutely essential for building the two-way connection between story-tellers and their audience. (21) This connection, in turn, is the very mechanism that propels the "communal creativity", which is, according to Jakobson and Bogatyrev, the mode of existence of folklore. 
Appendix: Transcript of the recording session

\begin{tabular}{|c|c|c|}
\hline $\begin{array}{c}\text { Recording, } \\
\text { minute }\end{array}$ & Text (22) & Translation \\
\hline $\begin{array}{l}{[21-1: 04]} \\
(23)\end{array}$ & $\begin{array}{l}\text { ГК ... у на́с ви́диш як | у | у } \\
\text { канто̂́рі коли́ жо̂ну́ грім у у | } \\
\text { сиділи три́ жо́ны | у канто̂́pi }\end{array}$ & $\begin{array}{l}\text { HK: ...In our village, you see } \\
\text { how...In the office when a } \\
\text { woman was } k[\text { illed] }(24) \text { by } \\
\text { lightning... Three women were } \\
\text { sitting in the office. }\end{array}$ \\
\hline [21-1:05] & 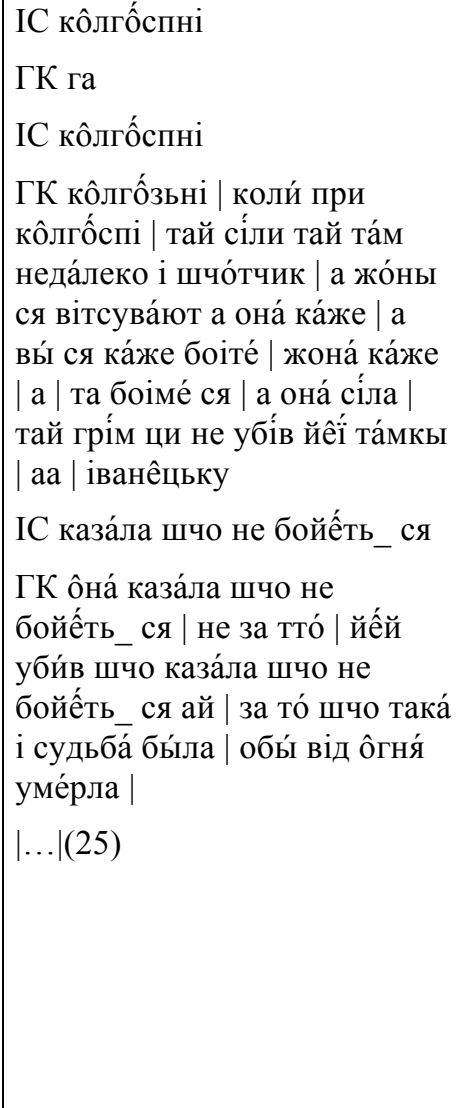 & $\begin{array}{l}\text { IS: Collective farms. } \\
\text { HK: What? } \\
\text { IS: Collective farms [office]. } \\
\text { HK: Collective farms. At the } \\
\text { time of collective farms. So } \\
\text { they sat down, and there was an } \\
\text { electric meter not far from } \\
\text { there, and [these] women } \\
\text { moved further from it, but she } \\
\text { said: oh, you are afraid? one } \\
\text { woman said. -- Sure, we are } \\
\text { afraid! And she sat there, and } \\
\text { you know, the lightning killed } \\
\text { her there. Her, Ivanycka. } \\
\text { IS: She said she was not afraid. } \\
\text { HK: She said she was not } \\
\text { afraid. Not because of that, she } \\
\text { got killed not because she said } \\
\text { she was not afraid, but because } \\
\text { it was her destiny, to die of fire. } \\
\text { [Interviewer: Have you heard } \\
\text { about someone predicting how } \\
\text { another person would die, and } \\
\text { later it would turn out to be } \\
\text { true?] }\end{array}$ \\
\hline \begin{tabular}{|l|} 
[21-1:06] \\
\end{tabular} & $\begin{array}{l}\text { ГК а я́ зна́ю } \\
|\ldots| \\
\text { ГК шчо́́з__бы́ло тако́є бы́ло } \\
\text { тако́є | }\end{array}$ & $\begin{array}{l}\text { HK: I don't know. } \\
\text { [Interviewer: Or maybe } \\
\text { someone could predict the time } \\
\text { when he himself would die?] }\end{array}$ \\
\hline
\end{tabular}


Structure of a Story-Telling Performance Among

Carpatho-Rusyns in Zakarpats'ka Oblast' of Ukraine

\begin{tabular}{|c|c|c|}
\hline $\begin{array}{c}\text { Recording, } \\
\text { minute }\end{array}$ & Text (22) & Translation \\
\hline & $\begin{array}{l}\text { IC но то́ я́к одно̂́му чоิлоิвіку } \\
\text { каза́ли хто́ тто́ каза́в шчо | ві́д } \\
\text { де́рева умре́ | коли́ гря́тка на } \\
\text { ньо́го упа́ла | } \\
\text { ГК а | тото́ | тото́ ішли́ | ішли́ } \\
\text { три́ жо́ны | бе́реме̂ньні | ай } \\
\text { ішо̂́в за ни́ми ді́до | та не́ | } \\
\text { ді́до | а́нгель_ішо̂́в | за нйми | } \\
\text { і ка́же | сье̂́сь ся уто́пит | оде̂́н } \\
\text { віт чо́го умре́ } \\
\text { ІС ... } \\
\text { ГК ... ві́т чо́го єде́н ка́же | }\end{array}$ & $\begin{array}{l}\text { HK: There was something, } \\
\text { there was something like that. } \\
\text { IS: Well, it is how one person } \\
\text { was told, who was that told } \\
\text { him, that he would die from a } \\
\text { tree? when a beam fell on him. } \\
\text { HK: Ah, that? Once, three } \\
\text { women were walking, three } \\
\text { pregnant women, and behind } \\
\text { them, an old man was walking. } \\
\text { It was not an old man, but an } \\
\text { angel, he walked after them and } \\
\text { he said: this one will drown, } \\
\text { one will - of what will he die? } \\
\text { IS: [unclear] } \\
\text { HK: [unclear] What will one die } \\
\text { of, he said? }\end{array}$ \\
\hline [21-1:07] & 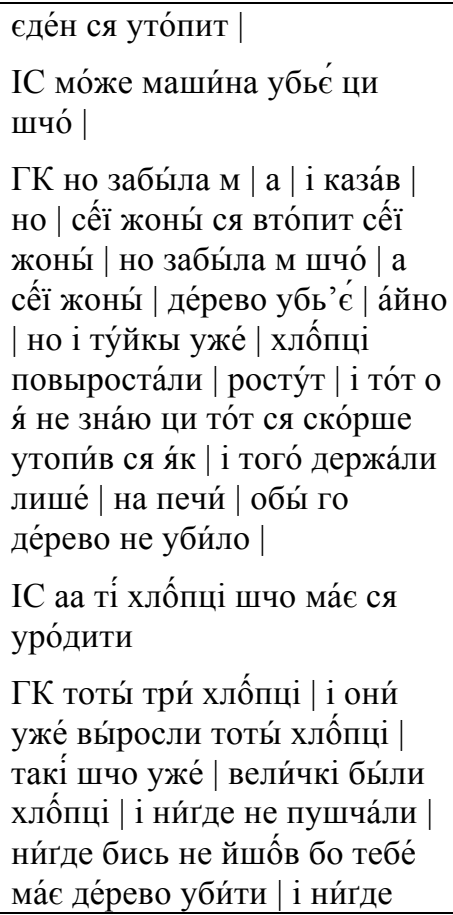 & $\begin{array}{l}\text { one will drown? } \\
\text { IS: Maybe he would be hit by a } \\
\text { car or something. } \\
\text { HK: Well, I forgot. So, and he } \\
\text { said, this woman's [child] will } \\
\text { drown, this woman's - I forgot } \\
\text { what, and this woman's [child] } \\
\text { will be killed by a tree. Yes. } \\
\text { And then boys already grew up, } \\
\text { they are growing, and that one, } \\
\text { I don't know if one drowned } \\
\text { first, or how, but that one was } \\
\text { only kept on the oven so that he } \\
\text { does not get killed by a tree... } \\
\text { IS: that was these boys who had } \\
\text { to be born... } \\
\text { HK: These three boys. And they } \\
\text { already grew up, these boys, so } \\
\text { that they were guys. And that } \\
\text { one, [his parents] did not let } \\
\text { him go anywhere, don't go }\end{array}$ \\
\hline
\end{tabular}




\begin{tabular}{|c|c|c|}
\hline $\begin{array}{l}\text { Recording, } \\
\text { minute }\end{array}$ & Text (22) & Translation \\
\hline & $\begin{array}{l}\text { бись не йшо̂́в | а давно́ бы́ли } \\
\text { такі́ | но | старі́ хыжі́ | така́ } \\
\text { бы́ла гря́тка | і гря́тка | тота́ } \\
\text { ся| }\end{array}$ & $\begin{array}{l}\text { anywhere because you will be } \\
\text { killed by a tree, don't go } \\
\text { anywhere. And long ago, there } \\
\text { were such old houses, and there } \\
\text { was such a beam, and that beam }\end{array}$ \\
\hline [21-1:08] & 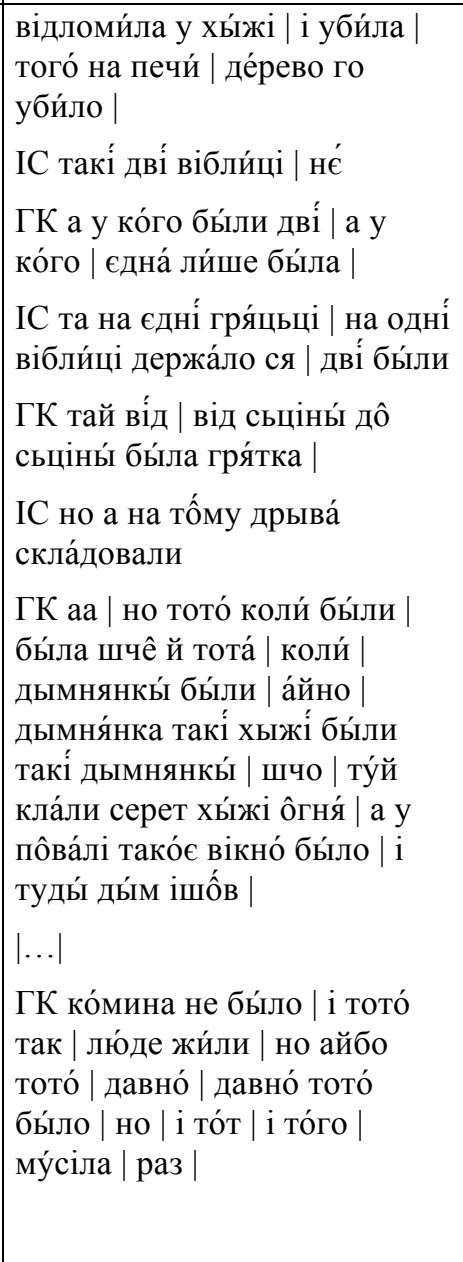 & $\begin{array}{l}\text { got broken in the house and } \\
\text { killed that one on the oven. He } \\
\text { was killed by a tree. } \\
\text { IS: There were such two beams. } \\
\text { HK: Some people had two, } \\
\text { some people had just one. } \\
\text { IS: So on one beam, on one } \\
\text { beam it was all supported, were } \\
\text { there two? } \\
\text { HK: And the beam was from } \\
\text { one wall to the other. } \\
\text { IS: People used to keep } \\
\text { firewood on that. } \\
\text { HK: Yes. It was when there } \\
\text { were...when there were houses } \\
\text { without chimney. Yes. Houses } \\
\text { without chimney, there were } \\
\text { such houses that here, in the } \\
\text { middle of the house they would } \\
\text { make fire, and there was such a } \\
\text { window in the ceiling, and the } \\
\text { smoke went there. } \\
\text { [Interviewer: There was no } \\
\text { chimney?] } \\
\text { HK: There was no chimney, } \\
\text { and people lived this way. But } \\
\text { that was long, long ago. And } \\
\text { so...it had to... }\end{array}$ \\
\hline $\begin{array}{l}21-1: 09] \\
\end{array}$ & $\begin{array}{l}\text { ві́ від де́рева мав уме́рти | ii } \\
\text { | так уме́р } \\
\text { IC і ни́гда не йшо̂́в лише́ у } \\
\text { ха́ті сидів | і гря́тка | }\end{array}$ & $\begin{array}{l}\text { he had to die of a tree, and that } \\
\text { is how he died. }\end{array}$ \\
\hline
\end{tabular}


Structure of a Story-Telling Performance Among

Carpatho-Rusyns in Zakarpats'ka Oblast' of Ukraine

\begin{tabular}{|c|c|c|}
\hline $\begin{array}{c}\text { Recording, } \\
\text { minute }\end{array}$ & Text (22) & Translation \\
\hline & $\begin{array}{l}\text { ГК і гря́тка тото́ ся } \\
\text { відломи́ла | і на ньо́го упа́ла | } \\
\text { і уби́ла і всьо́ | но́ а тре́тый я́ } \\
\text { забы́ла шо | } \\
\text { ІС маши́на його́ ма́ла уби́ти а } \\
\text { ну́ шчó | } \\
\text { ГК е та маши́н тогды́ не } \\
\text { бы́ло я́ не зна́ю | е | ма́в ся } \\
\text { задави́ти | но | єди́н ся } \\
\text { утопи́в | то́т ся ма́є задави́ти } \\
\text { а то́го ма́є де́рево уби́ти | тай } \\
\text { всьо́ | а́йно | і та то́го | ді́до } \\
\text { ви́казав і ді́да не ста́ло | а } \\
\text { ді́до за ты́ми жона́ми ішо̂́в | і } \\
\text { так каза́в | за ты́ми трьома́ } \\
\text { шчо ішли́ бе́ременьні перед } \\
\text { ни́м | } \\
\text { |... }\end{array}$ & $\begin{array}{l}\text { IS: And he did not go anywhere } \\
\text { ever, he only sat in the house, } \\
\text { and the beam... } \\
\text { HK: and the beam broke, and } \\
\text { fell on him, and killed him, and } \\
\text { that's all. And the third one, I } \\
\text { forgot what happened. } \\
\text { IS: He had to be killed by a car. } \\
\text { Do you remember? } \\
\text { HK: But there were no cars } \\
\text { then. I don't know. Ah, he had } \\
\text { to choke. Yes, one drowned, the } \\
\text { other had to choke, and the third } \\
\text { one had to be killed by a tree. } \\
\text { That's it. Yes. And that old } \\
\text { man, he said that and } \\
\text { disappeared. The old man went } \\
\text { after these women and said so, } \\
\text { after these three women that } \\
\text { were pregnant. } \\
\text { [Interviewer: So that was not an } \\
\text { old man?] }\end{array}$ \\
\hline$[21-$ & 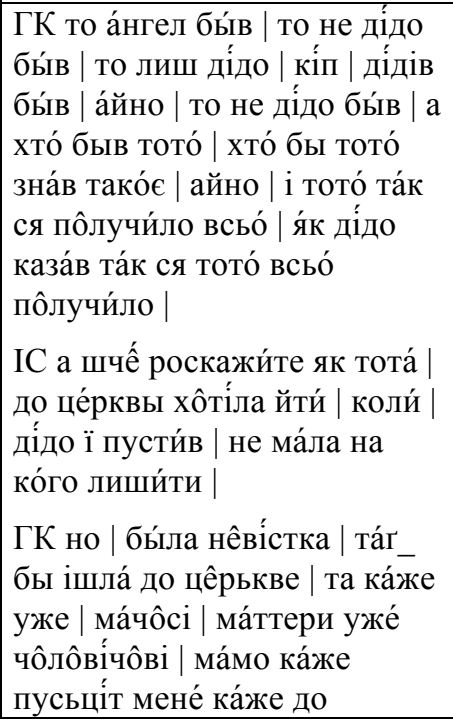 & $\begin{array}{l}\text { HK: That was an angel, not an } \\
\text { old man. He only looked like an } \\
\text { old man, that was not an old } \\
\text { man. But who else could know } \\
\text { that? And it all happened like } \\
\text { that, as the old man said, it all } \\
\text { happened like that. } \\
\text { IS: Also tell how that woman... } \\
\text { wanted to go to church when an } \\
\text { old man let her go. She did not } \\
\text { have anyone to leave her } \\
\text { children with. } \\
\text { HK. Yes. There was a young } \\
\text { woman, she wanted so much to } \\
\text { go to church, and she says to } \\
\text { her stepmother, to her } \\
\text { husband's mother: please let me }\end{array}$ \\
\hline
\end{tabular}




\begin{tabular}{|c|c|c|}
\hline $\begin{array}{c}\text { Recording, } \\
\text { minute }\end{array}$ & Text (22) & Translation \\
\hline & $\begin{array}{l}\text { це̂́рькви я́ бим ка́же та́к ішла́ } \\
\text { до це̂́рькви | а нє́т | я́ йду | } \\
\text { уже́ | ма́ти ка́же | я́ йду ты́ не } \\
\text { йде́ш | но і зобра́ла ся | i } \\
\text { пішла́ | ма́ти пішла́ | }\end{array}$ & $\begin{array}{l}\text { go to church, I want so much to } \\
\text { go to church. Oh no, I am going } \\
\text { to church, the mother[-in-law] } \\
\text { says, I am going, and you are } \\
\text { not. So she got ready and went, } \\
\text { the mother-[in-law]. }\end{array}$ \\
\hline [21-1:11] & 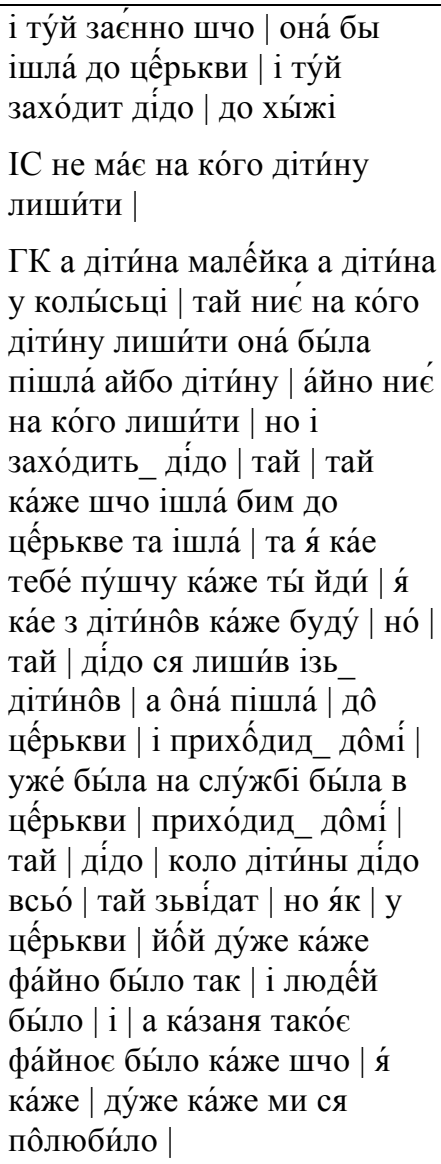 & $\begin{array}{l}\text { And this one wants so much to } \\
\text { go to church. And here an old } \\
\text { man enters the house. } \\
\text { IS: She did not have anyone to } \\
\text { leave a baby with. } \\
\text { HK: And the baby was little, } \\
\text { baby in the cradle. And there } \\
\text { was no one to leave the baby } \\
\text { with. She wanted to go, but } \\
\text { there was no one to leave the } \\
\text { baby with. And so an old man } \\
\text { comes in, and she says that she } \\
\text { wants to go to church, and he } \\
\text { says, I'll let you go, you may } \\
\text { go, I will stay with the baby, he } \\
\text { says. And she went to church. } \\
\text { Then she returns home, she was } \\
\text { in the church, she was present at } \\
\text { the service. So she comes home, } \\
\text { and the old man is sitting with } \\
\text { the baby. And he asks: how was } \\
\text { it in the church? She says: oh, it } \\
\text { was so good, there were a lot of } \\
\text { people, and the priest said such } \\
\text { a fine sermon. I liked it very } \\
\text { much, she says. }\end{array}$ \\
\hline$[21-1: 12]$ & $\begin{array}{l}\text { IC про̂́поิвідь | роิзумієєе } \\
\text { ГК но | аа пі́п | а а а ді́до } \\
\text { ка́же | е | лю... | люде́й лише́ } \\
\text { тро́є бы́ло у це̂́рькви | а піп | } \\
\text { не ка́заня каза́в ай це... | } \\
\text { це́глу вози́в | ци зна́єте | }\end{array}$ & $\begin{array}{l}\text { IS: The sermon, you know? } \\
\text { HK: Yes. And the priest... and } \\
\text { the old man says, there were } \\
\text { only three people in the church, } \\
\text { and the priest did not say the } \\
\text { sermon, he was driving bricks. }\end{array}$ \\
\hline
\end{tabular}


Carpatho-Rusyns in Zakarpats'ka Oblast' of Ukraine

\begin{tabular}{|c|c|c|}
\hline Recording, & Text (22) & Translation \\
\hline & $\begin{array}{l}\text { це́гла | но | ка́же лиш | тро́є } \\
\text { люде́й бы́ло у це̂́рькви | та де́ } \\
\text { она́ ка́же | та де́ по̂́вна } \\
\text { це̂́рькоิв бы́ло люде́й мно́го | } \\
\text { тай піп фа́йноє ка́заня каза́в | } \\
\text { а ді́до о̂пья́т | лише́ тро́є } \\
\text { бы́ло в це̂́рькви | а піп | це́глу } \\
\text { вози́в | } \\
\text { ІС цілу́ слу́жбу | } \\
\text { ГК цілу́ слу́жбу | но | ни́ч | } \\
\text { іде́ тото́ іде́ | а то́ | усі́ ма́ли | } \\
\text { и́нчі думкы́ | не ду́мали ть́м | }\end{array}$ & $\begin{array}{l}\text { Do you know what bricks are? } \\
\text { Well. He says there were only } \\
\text { three people in the church. How } \\
\text { come, she says, the church was } \\
\text { full, there were a lot of people. } \\
\text { And the priest said a nice } \\
\text { sermon. And the old man says } \\
\text { again: there were only three } \\
\text { people in the church, and the } \\
\text { priest was driving bricks. } \\
\text { IS: The whole time of the } \\
\text { service. } \\
\text { HK: The whole time of the } \\
\text { service. OK. And that is, } \\
\text { everyone had other thoughts, } \\
\text { did not think about... }\end{array}$ \\
\hline [21-1:13] & 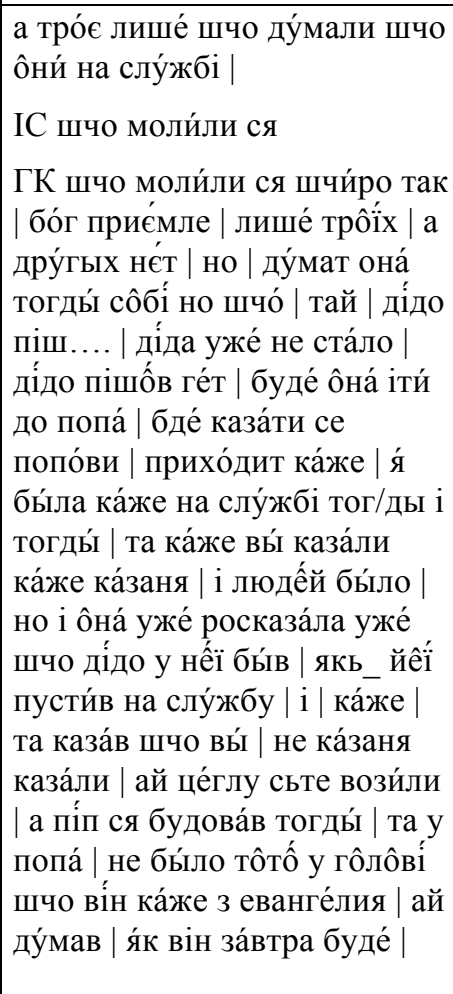 & $\begin{array}{l}\text { and there were only three } \\
\text { people who thought they were } \\
\text { at the service. } \\
\text { IS: Those who were praying. } \\
\text { HK: Those who were praying } \\
\text { from their heart, God accepts } \\
\text { only three, but not others. Well, } \\
\text { then she thinks to herself... The } \\
\text { old man disappeared, he went } \\
\text { away. She decided to go to the } \\
\text { priest, will tell that to the priest. } \\
\text { She comes to the priest and } \\
\text { says: I was, she says, at the } \\
\text { service then and then, and, she } \\
\text { says, you said a sermon, and } \\
\text { there were a lot of people. So } \\
\text { she told him that there was an } \\
\text { old man at her house, how he } \\
\text { let her go to the service, and, } \\
\text { she said, that old man said you } \\
\text { were not saying a sermon, but } \\
\text { driving bricks. And the priest } \\
\text { was building his house then, } \\
\text { and he did not think of what he }\end{array}$ \\
\hline
\end{tabular}




\begin{tabular}{|c|c|c|}
\hline $\begin{array}{c}\text { Recording, } \\
\text { minute }\end{array}$ & Text (22) & Translation \\
\hline & & $\begin{array}{l}\text { was saying from the Gospel, but } \\
\text { he was thinking, how he was } \\
\text { going to }\end{array}$ \\
\hline$[21-1: 14]$ & 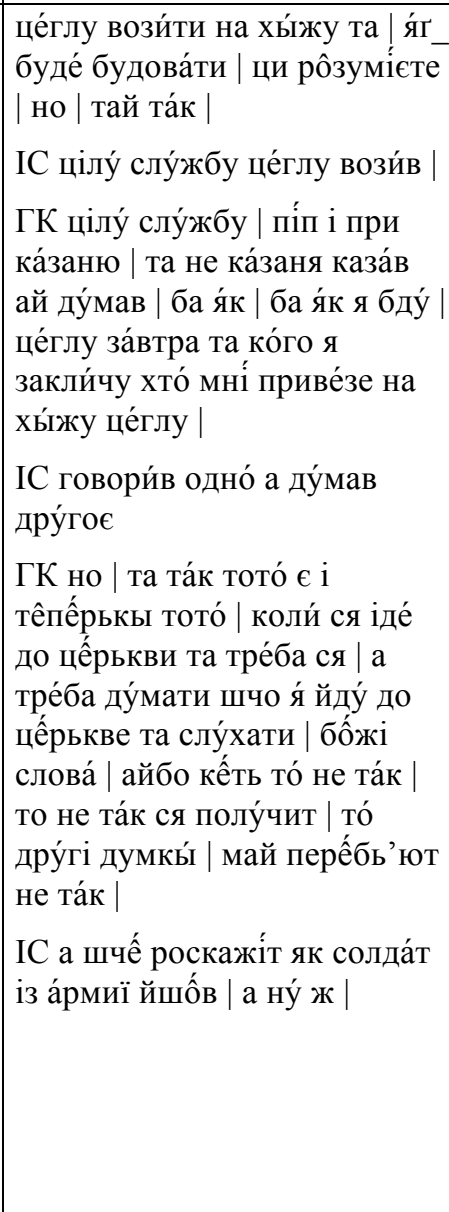 & $\begin{array}{l}\text { drive bricks the next day to } \\
\text { build his house, and how he will } \\
\text { build it. Do you understand? } \\
\text { Well, it was like that. } \\
\text { IS: During the whole service he } \\
\text { was driving bricks. } \\
\text { HK: During the whole service. } \\
\text { The priest, at the time of the } \\
\text { sermon... and he did not say the } \\
\text { sermon, but he was thinking, } \\
\text { but how I am going to...the } \\
\text { bricks tomorrow, who I could } \\
\text { call that would drive the bricks } \\
\text { for me so that I could build the } \\
\text { house. } \\
\text { IS: He was saying one thing, } \\
\text { and thinking another thing. } \\
\text { HK: Yes. So that's how it is } \\
\text { now too, when one goes to } \\
\text { church one needs to think that I } \\
\text { am going to church, and listen } \\
\text { to God's word. But what to do } \\
\text { if it is not so, it happens } \\
\text { otherwise, other thoughts } \\
\text { interfere, right? } \\
\text { IS: And also tell the story how a } \\
\text { soldier was returning from the } \\
\text { army, please, }\end{array}$ \\
\hline [21-1:15] & $\begin{array}{l}\text {... забы́ли | } \\
\text { ГК но та та́к шчо ішо́в быв | } \\
\text { ішо̂́в із | сол... | із а́рміi } \\
\text { солда́т | і ту́йкы уже́ ся } \\
\text { приме̂́рькло ні́ч | } \\
\text { ІС маши́н не бы́ло так як } \\
\text { те̂пе̂́рь }\end{array}$ & $\begin{array}{l}\text { have you forgotten it? } \\
\text { HK: So it was this way: a } \\
\text { soldier was returning from the } \\
\text { army, and it already became } \\
\text { dark, the night started. } \\
\text { IS: There were no cars, as there } \\
\text { are now. }\end{array}$ \\
\hline
\end{tabular}


Carpatho-Rusyns in Zakarpats'ka Oblast' of Ukraine

\begin{tabular}{|c|c|c|}
\hline $\begin{array}{c}\text { Recording, } \\
\text { minute }\end{array}$ & Text (22) & Translation \\
\hline & 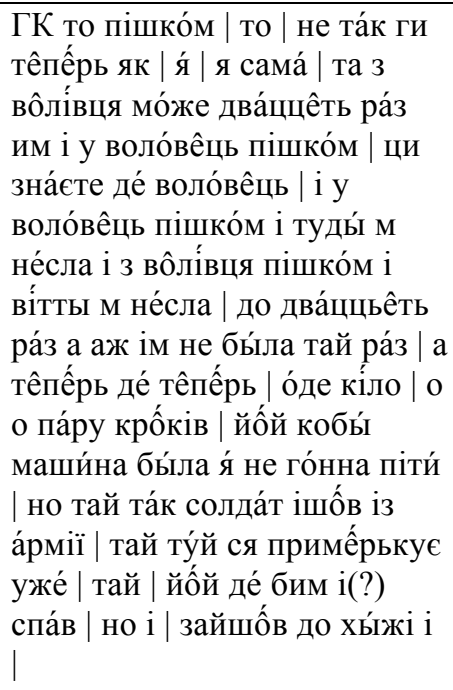 & $\begin{array}{l}\text { HK: So he had to go on foot, } \\
\text { not as now. Even I, from and to } \\
\text { Volovec, I went there maybe } \\
\text { twenty times on foot. Do you } \\
\text { know where Volovec is? So I } \\
\text { went there and back on foot, } \\
\text { twenty times, carrying loads. } \\
\text { And now, forget it. If I have a } \\
\text { kilogram to carry, a couple of } \\
\text { steps, oh I wish there was a car, } \\
\text { I cannot walk! OK, so the } \\
\text { soldier was returning from the } \\
\text { army, and it was becoming } \\
\text { dark. He thinks: where will I } \\
\text { sleep? He entered one house, }\end{array}$ \\
\hline [21-1:16] & 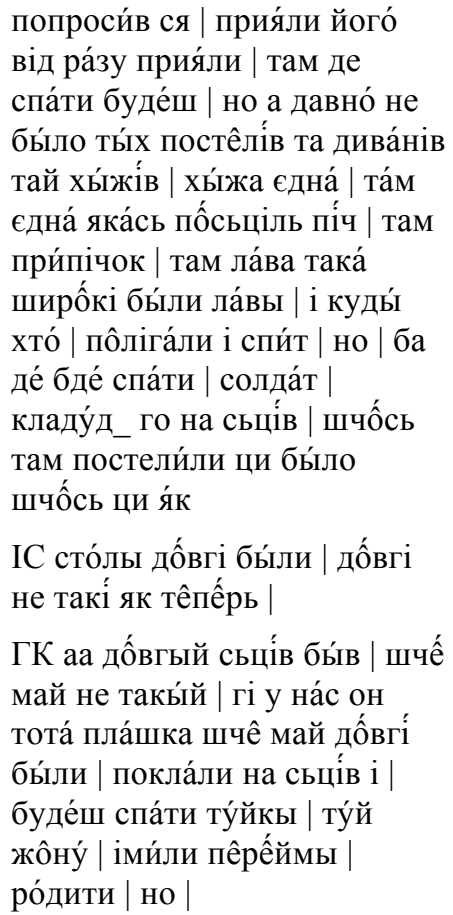 & $\begin{array}{l}\text { and asked if he could sleep } \\
\text { there. They agreed at once. } \\
\text { Where will you sleep? And long } \\
\text { ago there were no beds or } \\
\text { coaches or many rooms. There } \\
\text { was one room, and there was } \\
\text { one bed, one oven, a bench next } \\
\text { to an oven, and a bench, such } \\
\text { wide benches. And people slept } \\
\text { where they could, they lied } \\
\text { down and slept. And where } \\
\text { should the soldier sleep? They } \\
\text { put him on the table. They put } \\
\text { some cloth there, I don't know } \\
\text { whether there was something. } \\
\text { IS: Tables were long ag that } \\
\text { time, long, not as now. } \\
\text { HK: Yes, the table was long. } \\
\text { Maybe even longer than our } \\
\text { table, here with this board, that } \\
\text { table was still longer. So they } \\
\text { put him on the table, "you will }\end{array}$ \\
\hline
\end{tabular}




\begin{tabular}{|c|c|c|}
\hline Recording, & Text (22) & Translation \\
\hline & & $\begin{array}{l}\text { sleep here". And a woman went } \\
\text { into labor, she will have a baby. }\end{array}$ \\
\hline [21-1:17] & 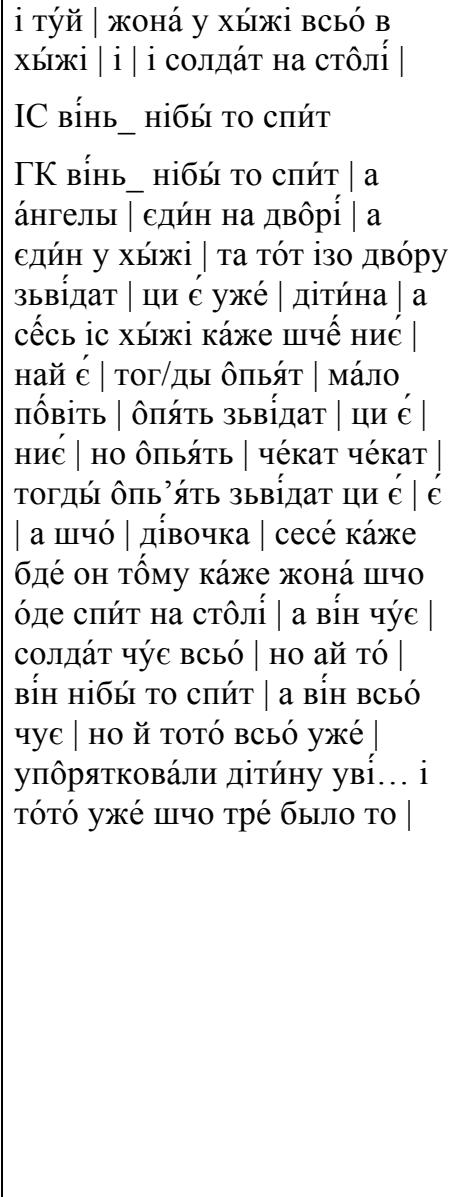 & $\begin{array}{l}\text { And there, the woman is in the } \\
\text { house, everything is in the } \\
\text { house, and the soldier is on the } \\
\text { table. } \\
\text { IS: He is pretending that he is } \\
\text { asleep. } \\
\text { HK: He is pretending that he is } \\
\text { asleep. And the angels, one in } \\
\text { the yard and the other in the } \\
\text { house, and the one from the } \\
\text { outside asks: is there a baby } \\
\text { already? and the one from the } \\
\text { house answers, not yet. Then } \\
\text { again, a bit later he asks again, } \\
\text { if there is a baby. Not yet. And } \\
\text { again. He waits, waits, and then } \\
\text { he asks again if there is a baby. } \\
\text { Yes, there is. And who is it? A } \\
\text { girl. This girl, he says, will be } \\
\text { married to that guy who is } \\
\text { asleep there on the table. And } \\
\text { he hears, the soldier hears } \\
\text { everything. Well, and... He } \\
\text { pretends he is asleep, but he } \\
\text { hears everything. And all that } \\
\text { already...they did what they } \\
\text { had to do with the baby, } \\
\text { swaddled it...everything that } \\
\text { was necessary, }\end{array}$ \\
\hline [21-1:18] & 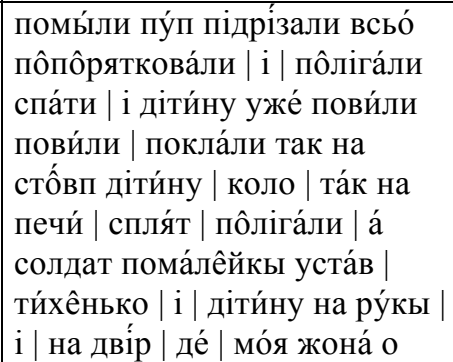 & $\begin{array}{l}\text { they washed the baby, cut the } \\
\text { umbilical cord, did everything, } \\
\text { and went to sleep. And the baby } \\
\text { was swaddled and put on the } \\
\text { oven, next to the people who } \\
\text { were sleeping on the oven. So } \\
\text { they went to sleep and the } \\
\text { soldier got up quietly, and took } \\
\text { the baby and went outside. }\end{array}$ \\
\hline
\end{tabular}


Structure of a Story-Telling Performance Among

Carpatho-Rusyns in Zakarpats'ka Oblast' of Ukraine

\begin{tabular}{|c|c|c|}
\hline $\begin{array}{l}\text { Recording, } \\
\text { minute }\end{array}$ & Text (22) & Translation \\
\hline & 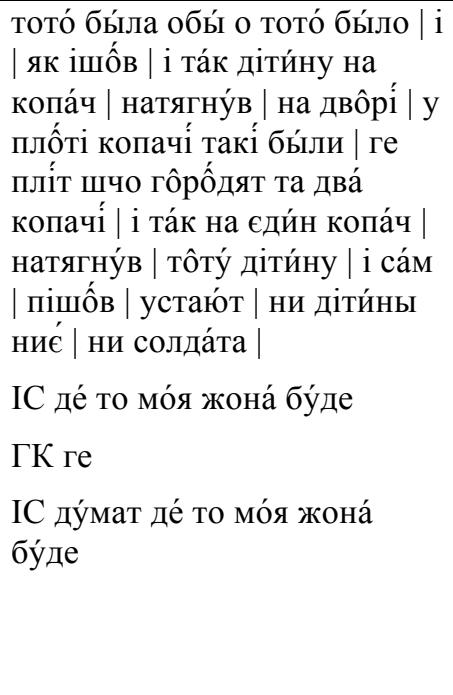 & $\begin{array}{l}\text { "How come that will be my } \\
\text { wife!" and as he was walking, } \\
\text { he put the baby on the stick, in } \\
\text { the yard, there were such sticks } \\
\text { in the fence, so when they make } \\
\text { a fence there are two such } \\
\text { [vertical] poles, so he } \\
\text { put/impaled the baby on one of } \\
\text { the poles, and went away. The } \\
\text { people woke up, there is neither } \\
\text { the baby there, nor the soldier. } \\
\text { IS: "How come that will be my } \\
\text { wife!" } \\
\text { HK: What? } \\
\text { IS: He thinks, how come she } \\
\text { will be his wife. }\end{array}$ \\
\hline [21-1:19] & 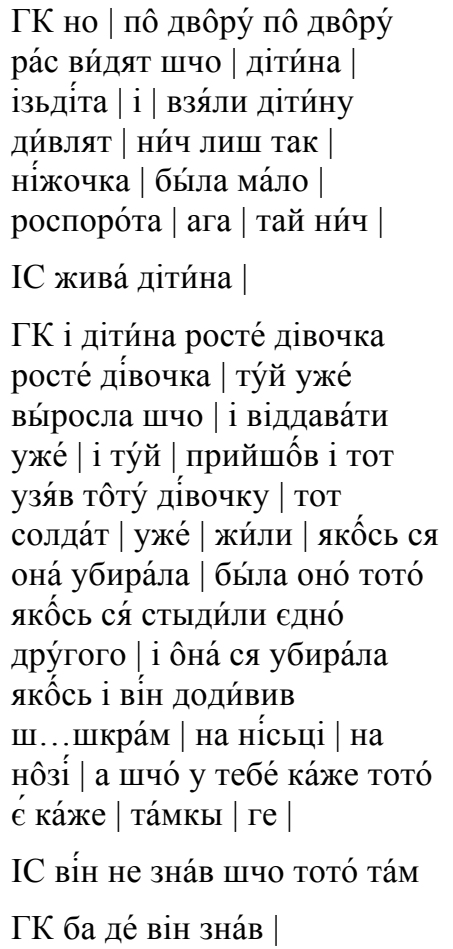 & $\begin{array}{l}\text { HK: Yes. And they went in the } \\
\text { yard, and they see that the baby } \\
\text { is on the stick, and they took the } \\
\text { baby and they see, there is } \\
\text { nothing, only one leg was a } \\
\text { little cut. OK. } \\
\text { IS: The baby was alive. } \\
\text { HK: And the girl is growing up, } \\
\text { growing up. Then already she } \\
\text { grew up and it is time to arrange } \\
\text { a marriage. And there, he came } \\
\text { and married that girl, that } \\
\text { soldier. And they already lived } \\
\text { together. And once she } \\
\text { somehow got dressed, because } \\
\text { they were a bit ashamed of each } \\
\text { other. And she got dressed, and } \\
\text { he somehow saw the scar on the } \\
\text { leg, on the leg. And what do } \\
\text { you have here, he asked, there. } \\
\text { IS: He did not know it was } \\
\text { there. }\end{array}$ \\
\hline
\end{tabular}




\begin{tabular}{|c|c|c|}
\hline $\begin{array}{c}\text { Recording, } \\
\text { minute }\end{array}$ & Text (22) & Translation \\
\hline & & HK: Of course he did not know. \\
\hline [21-1:20] & 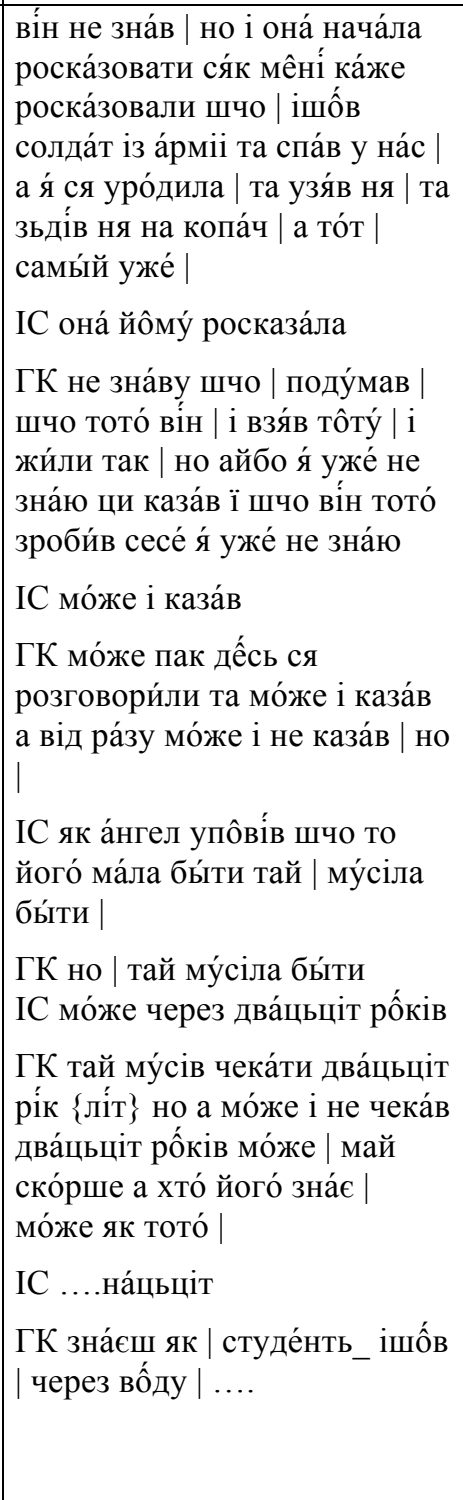 & $\begin{array}{l}\text { He did not know. So she started } \\
\text { telling him: I was told, she tells } \\
\text { him, that a soldier was returning } \\
\text { from the army and he stayed for } \\
\text { a night in our house, and I was } \\
\text { born, and he took me and } \\
\text { impaled me on a stick, and that } \\
\text { one, that very one... } \\
\text { IS: She told him. } \\
\text { HK: I do not know. He } \\
\text { thought... that was he... And he } \\
\text { had married her, and they lived } \\
\text { together. But I don't know if he } \\
\text { told her that it was he who had } \\
\text { done that, I don't know that. } \\
\text { IS: Maybe he did tell her. } \\
\text { HK: Maybe later, when they } \\
\text { were talking, maybe he told her, } \\
\text { but right then maybe he did not. } \\
\text { Yes. } \\
\text { IS: As the angel said that she } \\
\text { had to be his wife, so she had to } \\
\text { become his wife. } \\
\text { HK: Yes, she had to become his } \\
\text { wife. } \\
\text { IS: Maybe in twenty years. } \\
\text { HK: And he had to wait twenty } \\
\text { years. Or maybe he did not wait } \\
\text { twenty years, maybe earlier, } \\
\text { who knows. Maybe... } \\
\text { IS [unclear] } \\
\text { HK: You know how a student } \\
\text { crossed a river. [unclear] }\end{array}$ \\
\hline \begin{tabular}{|l|l|}
{$[21-1: 21]$} \\
\end{tabular} & \begin{tabular}{|l} 
ді́до прика́зовав | ішо́́в \\
студе́нт | іш_шко́лы | a \\
ту́йкы | надыйшла́ бу́ря | туй
\end{tabular} & $\begin{array}{l}\text { Our old man used to tell. A } \\
\text { student was going home from } \\
\text { school. And there a storm came, }\end{array}$ \\
\hline
\end{tabular}


Carpatho-Rusyns in Zakarpats'ka Oblast' of Ukraine

\begin{tabular}{|c|c|c|}
\hline $\begin{array}{l}\text { Recording, } \\
\text { minute }\end{array}$ & Text (22) & Translation \\
\hline & $\begin{array}{l}\text { до́шч | вода́ | тре́ба бы йти́ | a } \\
\text { дідо іде́ із во́лы | тоты́ | a | ге | } \\
\text { но | якы́сь ді́до } \\
\text { ІС пішо̂́в на дрыва́ } \\
\text { ГК ци на дрыва́ ішо̂́в ци де́ | } \\
\text { ка́же | вы́ бы ка́же мене́ не } \\
\text { переве́зли | через рікý | a | та } \\
\text { переве́зу тя ка́же | но a | та ты́ } \\
\text { шчо́ за єде́́ | я́ ка́же студе́нт | } \\
\text { но | а шчо́ бы ты́ роби́в як бы } \\
\text { | серед воды́ | быкы́ ся } \\
\text { вы́прягли | }\end{array}$ & $\begin{array}{l}\text { rain. There was a river. He had } \\
\text { to cross, and there is an old man } \\
\text { going by a cart with oxen. } \\
\text { That... well, some old man. } \\
\text { IS: He went to get firewood. } \\
\text { HK: Maybe to get forewood, or } \\
\text { for some other reason. He says: } \\
\text { could you give me a ride across } \\
\text { the river? OK, he says, I will } \\
\text { give you a ride, and who are } \\
\text { you? He says, I am a student. -- } \\
\text { Well, and what would you do if } \\
\text { in the middle of the river the } \\
\text { oxen get unharnessed, }\end{array}$ \\
\hline$[21-$ & 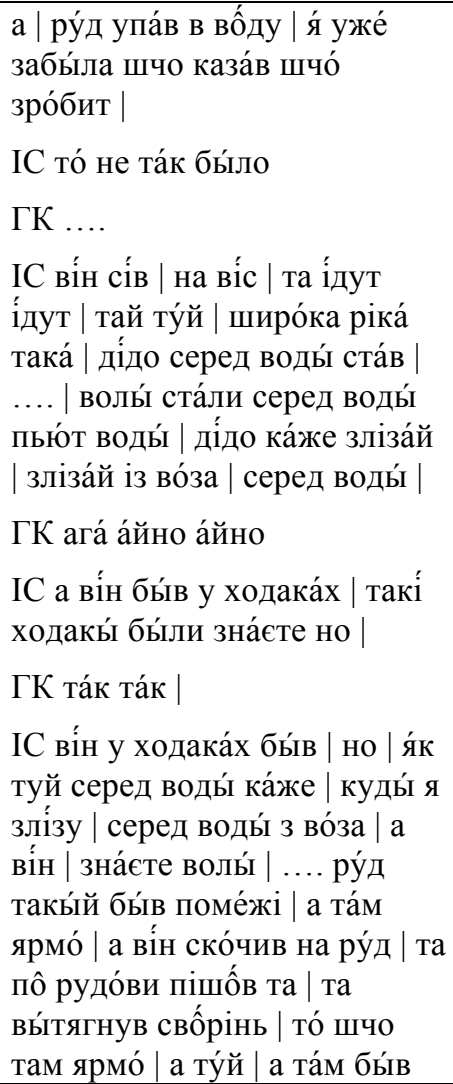 & $\begin{array}{l}\text { and the pole falls into the } \\
\text { water? I already forgot what he } \\
\text { said he would do. } \\
\text { IS: No, it was differently. } \\
\text { HK: [unclear] } \\
\text { IS: He got into the cart, and } \\
\text { they started off. And here, the } \\
\text { river was so wide, and the old } \\
\text { man stopped the cart in the } \\
\text { middle of the river. The oxen } \\
\text { have stopped in the middle of } \\
\text { the river, and they are drinking } \\
\text { the water. The old man says, get } \\
\text { off the cart. In the middle of the } \\
\text { river. } \\
\text { HK: Yes, yes, yes. } \\
\text { IS: And he was wearing } \\
\text { homemade shoes. Such } \\
\text { homemade shoes, do you know } \\
\text { what these are. } \\
\text { HK: Right, right. } \\
\text { IS: He was wearing such shoes. } \\
\text { Well, how I can get off the cart } \\
\text { here in the middle of the river, }\end{array}$ \\
\hline
\end{tabular}




\begin{tabular}{|c|c|c|}
\hline $\begin{array}{c}\text { Recording, } \\
\text { minute }\end{array}$ & Text (22) & Translation \\
\hline & $\begin{array}{l}\text { такы́́й .... сі́́ на ярмо́ іми́в } \\
\text { ся за ро́гы | тай } \mid \\
\text { ГК тай пішо̂́в | } \\
\text { ІС перене́сли | воль́ його́ на } \\
\text { то̂́__бік | }\end{array}$ & $\begin{array}{l}\text { in the middle of the river. And } \\
\text { he... you know, oxen... there } \\
\text { was such a pole between the } \\
\text { two oxen, and the yoke was on } \\
\text { it, and he jumped on this pole, } \\
\text { and went on the pole, and } \\
\text { pulled out the peg that was } \\
\text { holding that yoke... and there } \\
\text { was such a... and he sat on the } \\
\text { yoke and grabbed the horns... } \\
\text { HK: And off he went. } \\
\text { IS: The oxen carried him on the } \\
\text { other bank. }\end{array}$ \\
\hline$[21-1: 23]$ & 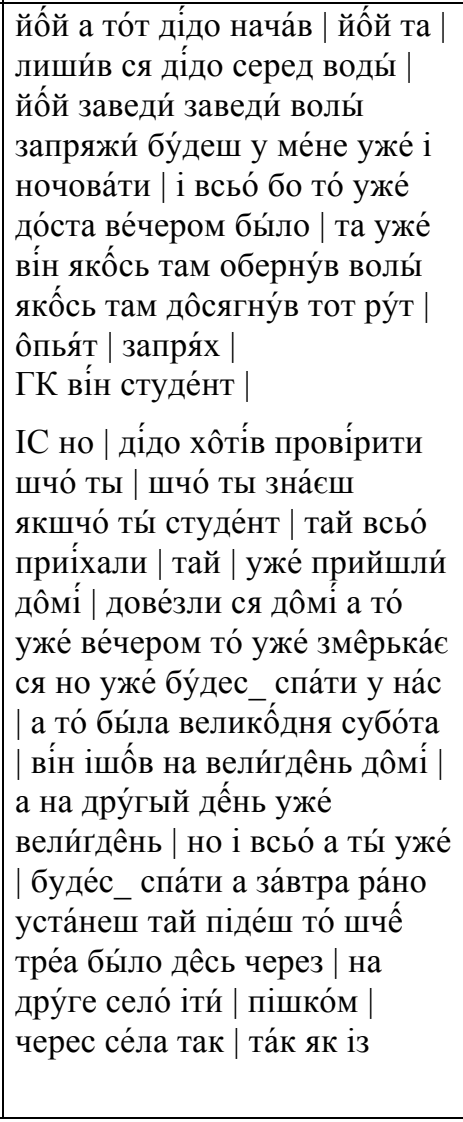 & $\begin{array}{l}\text { And that old man started... So } \\
\text { that old man was left in the } \\
\text { middle of the river. Oh, bring } \\
\text { back the oxen, harness them, I } \\
\text { will let you sleep in my house. } \\
\text { And that's it, because it was } \\
\text { already in the evening. And he } \\
\text { somehow turned the oxen } \\
\text { around, somehow reached that } \\
\text { pole, and harnessed the oxen } \\
\text { again. } \\
\text { HK: That student did. } \\
\text { IS: Yes. The old man wanted to } \\
\text { check what you... what do you } \\
\text { know if you are a student. And } \\
\text { well, they came home. They } \\
\text { came home, and that was } \\
\text { already in the evening, and it } \\
\text { was getting dark. "So you will } \\
\text { sleep in our house." And it was } \\
\text { the Saturday before Easter. He } \\
\text { was going home for Easter. And } \\
\text { the next day is already Easter. } \\
\text { "OK, so you will sleep here, } \\
\text { and tomorrow early you will get } \\
\text { up and go," he still needed to go } \\
\text { to the next village, on foot }\end{array}$ \\
\hline
\end{tabular}


Structure of a Story-Telling Performance Among

Carpatho-Rusyns in Zakarpats'ka Oblast' of Ukraine

\begin{tabular}{|c|c|c|}
\hline $\begin{array}{c}\text { Recording, } \\
\text { minute }\end{array}$ & Text (22) & Translation \\
\hline & $\begin{array}{l}\text { воิлівця́ як вы́ ка́жете | но і } \\
\text { ни́ч айбо то́ ишче̂́ | гусака́ | }\end{array}$ & $\begin{array}{l}\text { through several villages. So as } \\
\text { from Volovec, as you were } \\
\text { saying. OK, and there also, they } \\
\text { need to slaughter a goose, }\end{array}$ \\
\hline [21-1:24] & 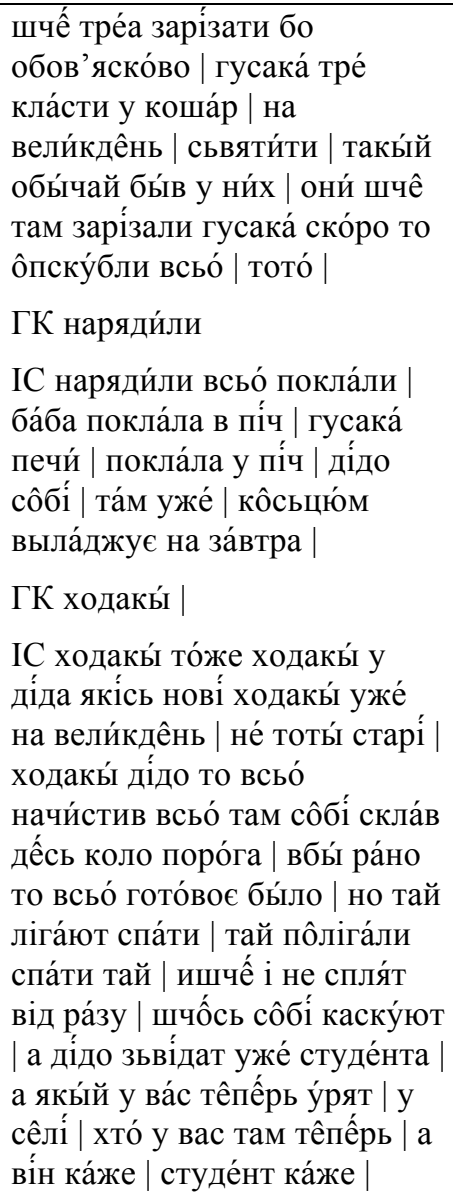 & $\begin{array}{l}\text { because it is necessary to put a } \\
\text { roasted goose in the basket on } \\
\text { Easter, to bless it, they had such } \\
\text { a custom. They slaughtered the } \\
\text { goose, plucked it fast, all that. } \\
\text { HK: Dressed it. } \\
\text { IS: Dressed it, put everything } \\
\text { there. And the wife put the } \\
\text { goose in the oven to bake. She } \\
\text { put it in the oven. The old man } \\
\text { is preparing his clothes for the } \\
\text { next day. } \\
\text { HK: The shoes. } \\
\text { IS: The shoes, also the shoes. } \\
\text { The old man had some new } \\
\text { shoes for Easter, not those old } \\
\text { shoes. So the old man cleaned } \\
\text { all that, and put all that together } \\
\text { somewhere near the threshold } \\
\text { so that in the morning all that is } \\
\text { ready. And they go to sleep. } \\
\text { And they went to sleep, but still } \\
\text { they are not sleeping, still } \\
\text { talking. And the old man asks } \\
\text { the student: and who is in } \\
\text { power in your village now? } \\
\text { Who is the boss? And he says, } \\
\text { the student says, }\end{array}$ \\
\hline$[21-1: 25]$ & 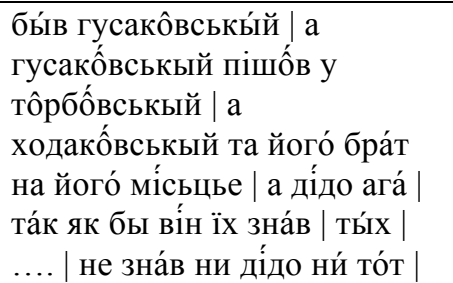 & $\begin{array}{l}\text { Mr. Goose was before, but Mr. } \\
\text { Goose went to Bag-Town, and } \\
\text { Mr. Shoe and his brother are in } \\
\text { his place. And the old man says, } \\
\text { yes, as if he knew them. These } \\
\text { people. He did not know, } \\
\text { neither the old man nor the }\end{array}$ \\
\hline
\end{tabular}




\begin{tabular}{|c|c|c|}
\hline $\begin{array}{c}\text { Recording, } \\
\text { minute }\end{array}$ & Text (22) & Translation \\
\hline & 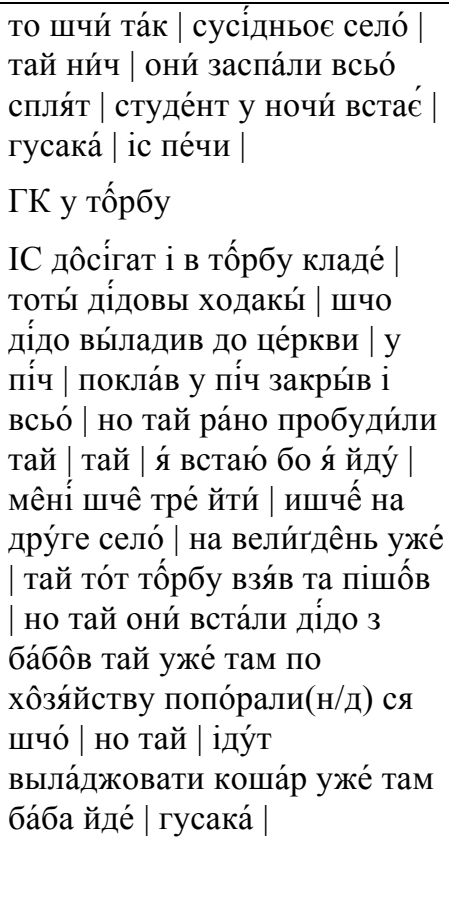 & $\begin{array}{l}\text { student. It was the next village. } \\
\text { OK. They went to sleep, fell } \\
\text { asleep. In the night the student } \\
\text { gets up, takes the goose from } \\
\text { the oven... } \\
\text { HK: Into his bag. } \\
\text { IS: He takes the goose and puts } \\
\text { it in his bag. And the old man's } \\
\text { shoes that the old man prepared } \\
\text { to go to church in, he put them } \\
\text { in the oven, closed it, and that's } \\
\text { it. So in the morning they woke } \\
\text { up and [he says]: I am getting } \\
\text { up because I need to go to the } \\
\text { next village for Easter. And he } \\
\text { took the bag and off he went. } \\
\text { And they got up, the old man } \\
\text { and his wife, and took care of } \\
\text { the household. And then they } \\
\text { are going to prepare the basket, } \\
\text { and the wife goes to get the } \\
\text { goose... }\end{array}$ \\
\hline [21-1:26] & 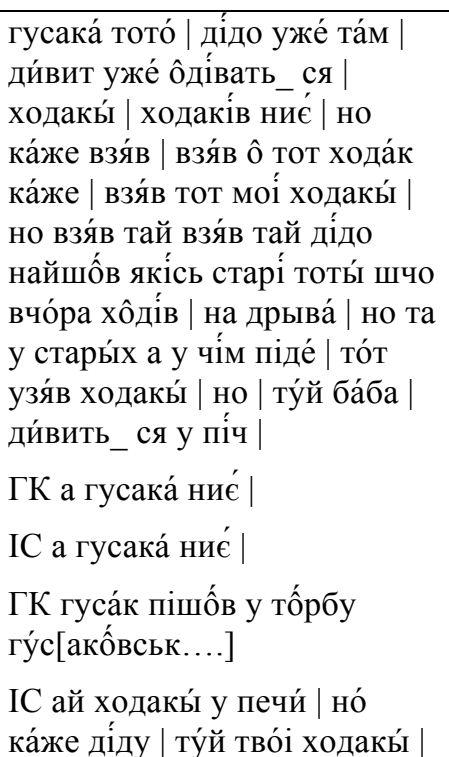 & $\begin{array}{l}\text { The goose... The old man } \\
\text { already is looking to put on the } \\
\text { shoes, and there are no shoes. } \\
\text { Well, he says, he took the } \\
\text { shoe...that guy took my shoes. } \\
\text { OK, so he took the shoes. So } \\
\text { the old man found some old } \\
\text { shoes that he was wearing the } \\
\text { day before when he had gone to } \\
\text { get firewood, and he had to go } \\
\text { in the old shoes, because there } \\
\text { was no choice, that guy took the } \\
\text { shoes. And then the woman } \\
\text { looked in the oven... } \\
\text { HK: And the goose is not there. } \\
\text { IS: And the goose is not there. }\end{array}$ \\
\hline
\end{tabular}


Structure of a Story-Telling Performance Among

Carpatho-Rusyns in Zakarpats'ka Oblast' of Ukraine

\begin{tabular}{|c|c|c|}
\hline $\begin{array}{l}\text { Recording, } \\
\text { minute }\end{array}$ & Text (22) & Translation \\
\hline & 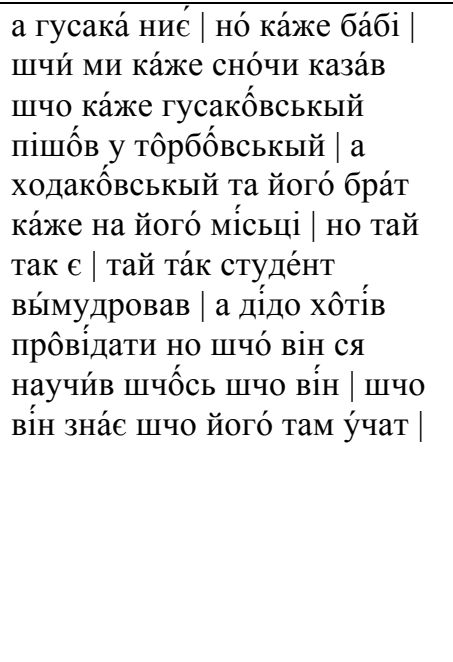 & $\begin{array}{l}\text { HK: The goose went into the } \\
\text { bag. Mr. Goose... } \\
\text { IS: And in the oven, there are } \\
\text { shoes. She says, old man, here } \\
\text { are your shoes, and there is no } \\
\text { goose here. Well, he says to the } \\
\text { woman, he told me last night } \\
\text { that Mr. Goose had gone to the } \\
\text { Bag-Town, and Mr. Shoe and } \\
\text { his brother, he said, were in his } \\
\text { place. And it was like this. Like } \\
\text { this, the student was smart. And } \\
\text { the old man wanted to check } \\
\text { what the student had learned. } \\
\text { What he knows, what they } \\
\text { teach them there. }\end{array}$ \\
\hline$[21-1: 27]$ & 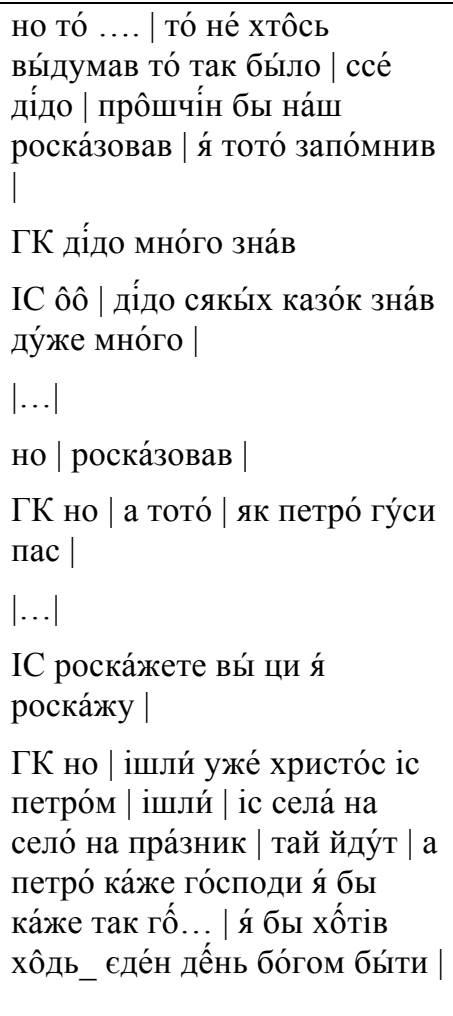 & $\begin{array}{l}\text { Well that... That is not that } \\
\text { someone made it up, it really } \\
\text { was like that. That is what our } \\
\text { old man, blessed be his soul, } \\
\text { used to tell. I remembered that. } \\
\text { HK: Our old man knew a lot. } \\
\text { IS: Oh, our old man knew a lot } \\
\text { of such stories. } \\
\text { [Interviewer: Did he by any } \\
\text { chance tell stories about Jesus } \\
\text { going around together with St. } \\
\text { Peter?] } \\
\text { IS: Yes, he told that. } \\
\text { HK: Well, and that one, how St. } \\
\text { Peter was herding geese. } \\
\text { [Interviewer: I haven't heard } \\
\text { that one, please tell it!] } \\
\text { IS: Will you tell or I should } \\
\text { tell? } \\
\text { HK: Well, Jesus and St. Peter } \\
\text { were going from one village to } \\
\text { another to the village church }\end{array}$ \\
\hline
\end{tabular}




\begin{tabular}{|c|c|c|}
\hline $\begin{array}{c}\text { Recording, } \\
\text { minute }\end{array}$ & Text (22) & Translation \\
\hline & & $\begin{array}{l}\text { feast. So they are walking, and } \\
\text { St. Peter says: Lord, I would } \\
\text { like so much to be God at least } \\
\text { for one day. }\end{array}$ \\
\hline$[21-1: 28]$ & 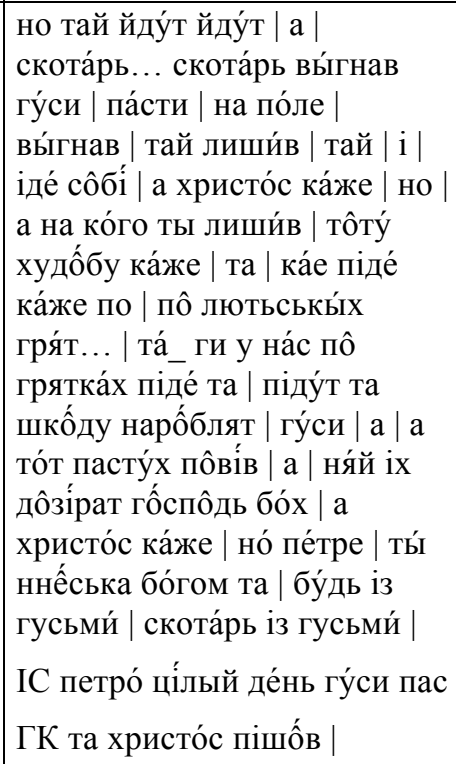 & $\begin{array}{l}\text { So they are going, and a person } \\
\text { has taken geese to a field to } \\
\text { graze, and has left them there, } \\
\text { and he is walking away, and } \\
\text { Christ asks: to who did you } \\
\text { leave these creatures to herd? } \\
\text { They will, he says, go to } \\
\text { people's gardens... as here, if } \\
\text { they go to vegetable patches, } \\
\text { they can make a lot of damage, } \\
\text { the geese. And that person said: } \\
\text { let God look after them. And } \\
\text { Christ said: listen, Peter, you } \\
\text { are God today, so be with the } \\
\text { geese, herd the geese. } \\
\text { IS: St. Peter was herding geese } \\
\text { for the whole day. } \\
\text { HK: And Christ went }\end{array}$ \\
\hline [21-1:29] & 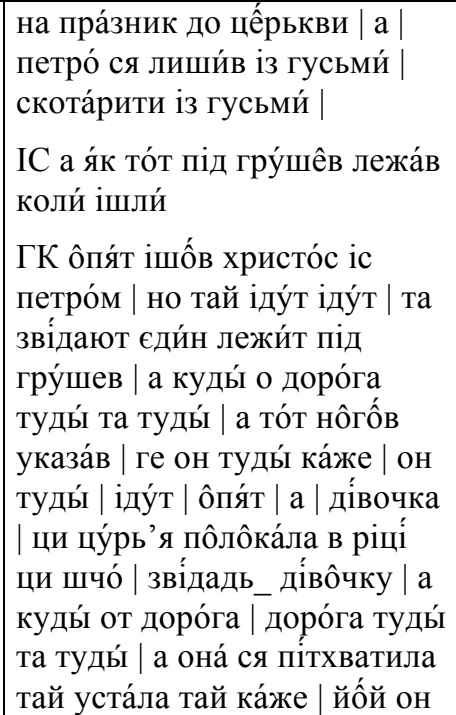 & $\begin{array}{l}\text { to church at the village church } \\
\text { feast, and St. Peter stayed with } \\
\text { the geese, herding geese. } \\
\text { IS: And how that guy was lying } \\
\text { under a pear-tree when they } \\
\text { were passing by? } \\
\text { HK: Again, Christ went } \\
\text { together with St. Peter, so they } \\
\text { are walking, and they ask, they } \\
\text { ask one guy lying under a pear } \\
\text { tree, "Where is the road there } \\
\text { and there?", and that guy } \\
\text { pointed with his leg. There, he } \\
\text { says. They go again, and a girl } \\
\text { was whether rinsing clothes in } \\
\text { the river, or something. They } \\
\text { ask the girl: where is that road }\end{array}$ \\
\hline
\end{tabular}


Structure of a Story-Telling Performance Among

Carpatho-Rusyns in Zakarpats'ka Oblast' of Ukraine

\begin{tabular}{|c|c|c|}
\hline $\begin{array}{l}\text { Recording, } \\
\text { minute }\end{array}$ & Text (22) & Translation \\
\hline & $\begin{array}{l}\text { туды́ он туды́ йо̂́й іді́т о туды́ } \\
\text { та о туды́ та о туды́ | }\end{array}$ & $\begin{array}{l}\text { there and there? And she came } \\
\text { and said: oh, there, and there, } \\
\text { oh, go there, and there. }\end{array}$ \\
\hline [21-1:30] & 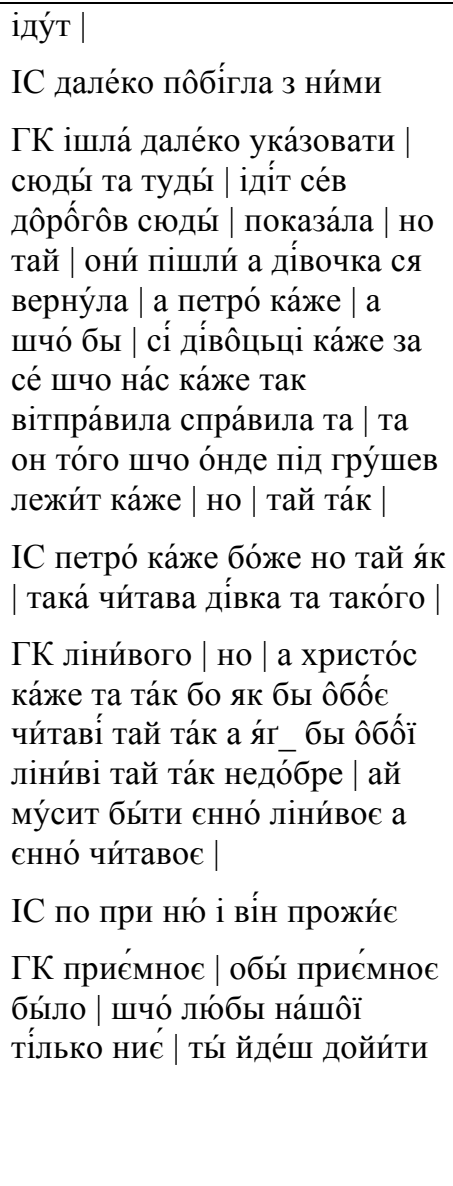 & $\begin{array}{l}\text { So they are going... } \\
\text { IS: She went far with them. } \\
\text { HK: She went far to show them } \\
\text { the way. Here, and there, take } \\
\text { this road there. She showed } \\
\text { them. And then, they went on } \\
\text { and the girl returned. And St. } \\
\text { Peter says: what will be given } \\
\text { to this girl that she showed us } \\
\text { the way? -- That one that is } \\
\text { lying under the pear-tree, Jesus } \\
\text { says. Well. And it was so. } \\
\text { IS: St. Peter says: Lord, but } \\
\text { how come, such a hard-working } \\
\text { girl and such a } \\
\text { HK: lazy one. Well. And Christ } \\
\text { says: it is because if they were } \\
\text { both hard-working, it will be } \\
\text { like this, and if both were lazy, } \\
\text { that is not good either, so it } \\
\text { must be one lazy person and } \\
\text { one hard-working. } \\
\text { IS: He will survive next to her. } \\
\text { HK: Good, that one person } \\
\text { should be good. Why is our } \\
\text { Luba not coming for so long? } \\
\text { Will you go and milk the cow? }\end{array}$ \\
\hline$[21-1: 31]$ & $\begin{array}{l}\text { IC шче́́ та́м шчоิсь ішли́ то́же } \\
\text { | шчо́ то шче̂́ бы́ло | а я́к | } \\
\text { петра́ жона́ би́ла | зна́єте } \\
\text { чу́ли сьте } \\
\text { ГК а | а | чу́ла | чу́ла м як } \\
\text { петра́ жона́ би́ла | давно́ | } \\
\text { давно́ так бы́ло шчо жо́ны | } \\
\text { жо́ны керьова́ли людьми́ | }\end{array}$ & $\begin{array}{l}\text { IS: There is another story, they } \\
\text { also went, what was it? How a } \\
\text { woman beat St. Peter? Do you } \\
\text { know, have you heard that one? } \\
\text { HK: Yes, I heard it, I heard how } \\
\text { a woman beat St. Peter. Long } \\
\text { ago, long ago it was so that } \\
\text { women bossed men around. }\end{array}$ \\
\hline
\end{tabular}




\begin{tabular}{|c|c|c|}
\hline $\begin{array}{l}\text { Recording, } \\
\text { minute }\end{array}$ & Text (22) & Translation \\
\hline & 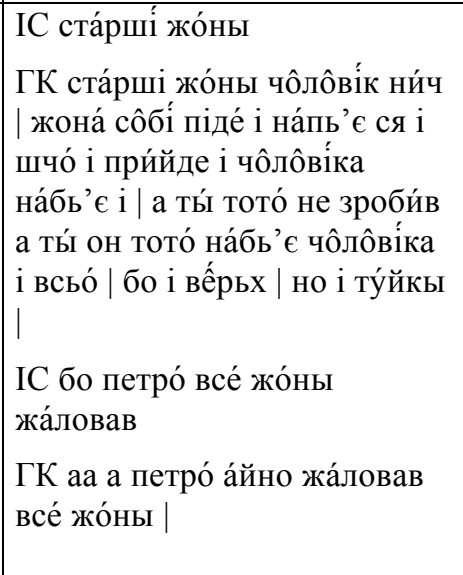 & $\begin{array}{l}\text { IS: Women were bosses. } \\
\text { HK: Women were bosses, and } \\
\text { men not at all. A wife would go } \\
\text { and get drunk, and come and } \\
\text { would beat a man: you did not } \\
\text { do that, you did not do this, and } \\
\text { she would beat her husband, } \\
\text { and that's it. Because she was } \\
\text { the boss. And here... } \\
\text { IS: Because St. Peter always } \\
\text { pitied women. } \\
\text { HK: Yes, St. Peter really always } \\
\text { pitied women, }\end{array}$ \\
\hline [21-1:32] & 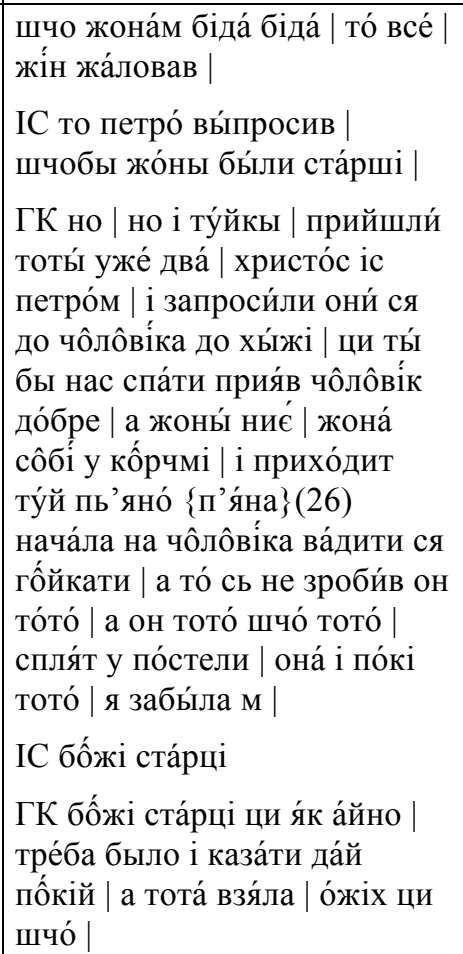 & $\begin{array}{l}\text { because women's life is hard, } \\
\text { so he always pitied women. } \\
\text { IS: That was Peter who asked } \\
\text { that women were bosses. } \\
\text { HK: Yes. And then... These } \\
\text { two already came, Christ and } \\
\text { St. Peter, and asked a man to let } \\
\text { them in his house, whether you } \\
\text { would let us sleep in your } \\
\text { house. The man goes: OK, and } \\
\text { the wife was not there, the wife } \\
\text { was at an inn. And she comes } \\
\text { back drunk, and starts yelling at } \\
\text { the husband, yelling, you did } \\
\text { not do this, you did not do that, } \\
\text { and what are these, sleeping in } \\
\text { the bed, and she... I forgot. } \\
\text { IS: God's old men. } \\
\text { HK: God's old men or what. } \\
\text { OK. He should have told her } \\
\text { "leave them alone". And she } \\
\text { took a poker or something }\end{array}$ \\
\hline [21-1:33] & $\begin{array}{l}\text { нача́ла би́ти а петро́ іс кра́ю } \\
\text { спа́в | а христо́с по при́ } \\
\text { сьціну | нача́ла петра́ би́ти }\end{array}$ & $\begin{array}{l}\text { and started beating... St. Peter } \\
\text { was in the bed on the edge, and } \\
\text { Christ was next to the wall. She }\end{array}$ \\
\hline
\end{tabular}


Structure of a Story-Telling Performance Among

Carpatho-Rusyns in Zakarpats'ka Oblast' of Ukraine

\begin{tabular}{|c|c|c|}
\hline $\begin{array}{l}\text { Recording, } \\
\text { minute }\end{array}$ & Text (22) & Translation \\
\hline & 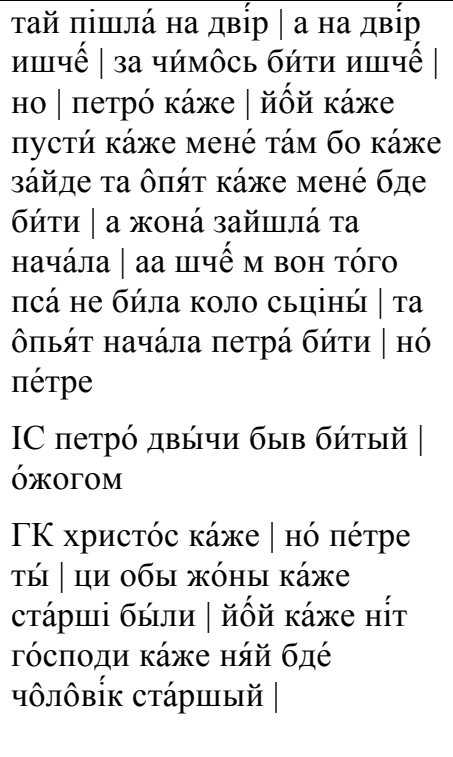 & $\begin{array}{l}\text { started beating St. Peter. And } \\
\text { went outside, to fetch } \\
\text { something else to beat with. } \\
\text { Well, St. Peter says: oh, he } \\
\text { says, let me there, because, he } \\
\text { says, she will come back and } \\
\text { she will beat me again. And the } \\
\text { woman come in and started... } \\
\text { oh, I haven't yet beaten that dog } \\
\text { next to the wall, and she started } \\
\text { to beat St. Peter again. Well, } \\
\text { Peter... } \\
\text { IS: St. Peter was beaten twice, } \\
\text { with a poker. } \\
\text { HK: Christ says, well, Peter, do } \\
\text { you still want women to be } \\
\text { bosses? Oh, Lord, no, he says, } \\
\text { let men be bosses. }\end{array}$ \\
\hline$[21-$ & 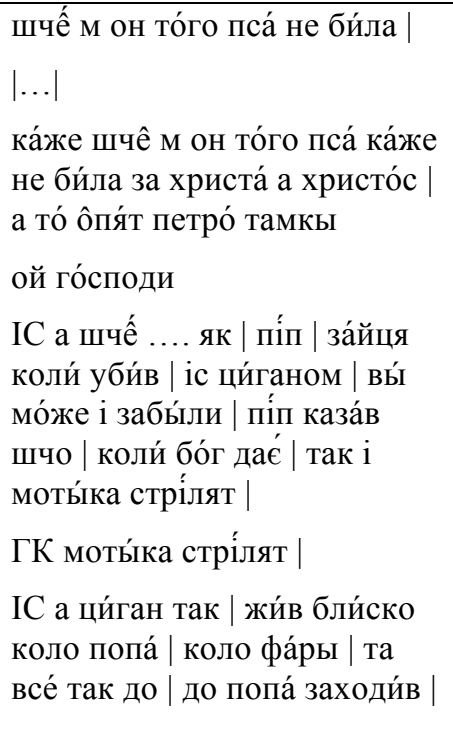 & $\begin{array}{l}\text { "I haven't yet beaten that dog"! } \\
\text { [Interviewer: What?] } \\
\text { HK: She says: "I haven't yet } \\
\text { beaten that dog", about Christ, } \\
\text { and Christ... and it's Peter } \\
\text { again there. Oh my God. } \\
\text { IS: And also... how the priest... } \\
\text { when he killed a rabbit, with the } \\
\text { Roma. You may have forgotten } \\
\text { this one. The priest said, when } \\
\text { God permits, a hoe fires. } \\
\text { HK: A hoe fires. } \\
\text { IS: And the Roma lived near } \\
\text { from the priest's house, and } \\
\text { always dropped by to the } \\
\text { priest's. }\end{array}$ \\
\hline [21-1:35] & $\begin{array}{l}\text { тай усе́ | .... коли́ бо́г дає́ так } \\
\text { і моты́ка стрі́лят пі́п ка́же | } \\
\text { тай ра́с ту́й | іде́ піп на оิхо̂́ту } \\
\text { | у попа́ бы́ла | пу́шка | а }\end{array}$ & $\begin{array}{l}\text { And [unclear] The priest says: if } \\
\text { God permits, even a hoe can } \\
\text { fire. And once the priest goes } \\
\text { hunting, the priest had a rifle, }\end{array}$ \\
\hline
\end{tabular}




\begin{tabular}{|c|c|c|}
\hline $\begin{array}{c}\text { Recording, } \\
\text { minute }\end{array}$ & Text (22) & Translation \\
\hline & 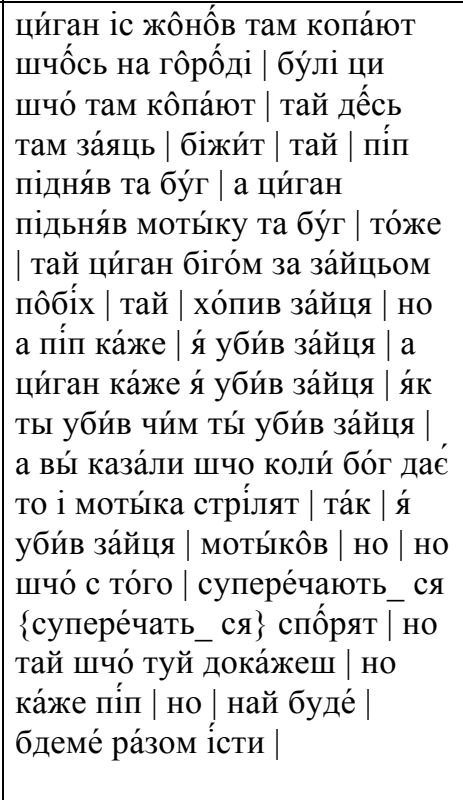 & $\begin{array}{l}\text { and the Roma and his wife are } \\
\text { digging something in the } \\
\text { garden, potatoes or something. } \\
\text { And here a rabbit runs. The } \\
\text { priest raised the rifle and bang. } \\
\text { And the Roma raised the hoe } \\
\text { and bang, also. And the Roma } \\
\text { ran after the rabbit and grabbed } \\
\text { the rabbit. The priest says: I } \\
\text { killed the rabbit, and the Roma } \\
\text { says: I killed the rabbit. -- How } \\
\text { did you kill it, what with? -- } \\
\text { And you said that when God } \\
\text { permits, a hoe can fire, so it was } \\
\text { me who killed the rabbit, with } \\
\text { my hoe. Well, so what? They } \\
\text { are arguing, arguing, but what } \\
\text { can you prove here. Well, the } \\
\text { priest says, let it be, we'll eat it } \\
\text { together, }\end{array}$ \\
\hline [21-1:36] & 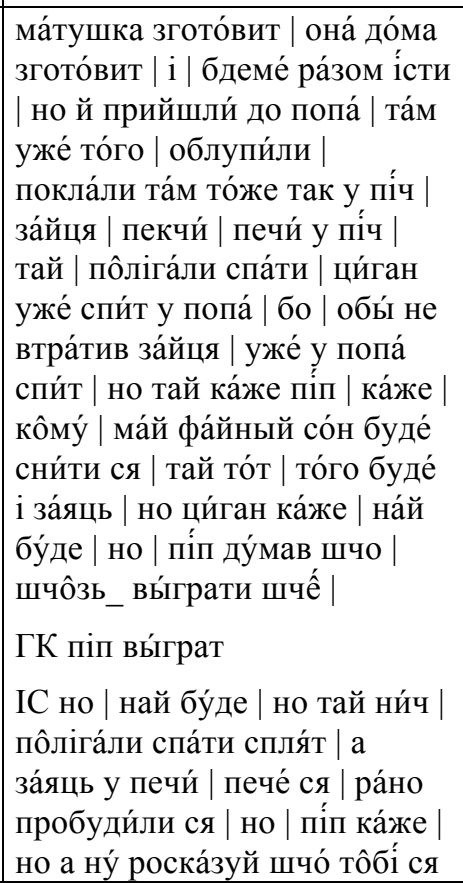 & $\begin{array}{l}\text { my wife will cook it, it will } \\
\text { cook it at home, and [we] will } \\
\text { eat it. Well, they came to the } \\
\text { priest's house, skinned the } \\
\text { rabbit, put it in the oven, to } \\
\text { bake the rabbit, and went to } \\
\text { sleep. The Roma is sleeping at } \\
\text { the priest's so that he does not } \\
\text { loose sight of the rabbit, he is } \\
\text { sleeping at the priest's. And the } \\
\text { priest says, the one who sees a } \\
\text { better dream, he will take the } \\
\text { rabbit. Well, OK, the Roma } \\
\text { says. The priest thought he } \\
\text { would win something. } \\
\text { HK: That the priest would win. } \\
\text { IS: Well, OK. OK. They went } \\
\text { to sleep, they are sleeping, and } \\
\text { the rabbit is in the oven, baking. } \\
\text { In the morning they woke up, } \\
\text { and the priest says: well, tell me }\end{array}$ \\
\hline
\end{tabular}


Structure of a Story-Telling Performance Among

Carpatho-Rusyns in Zakarpats'ka Oblast' of Ukraine

\begin{tabular}{|c|c|c|}
\hline $\begin{array}{c}\text { Recording, } \\
\text { minute }\end{array}$ & Text (22) & Translation \\
\hline & $\begin{array}{l}\text { сни́ло | ци́ганови ка́же | } \\
\text { ци́ган ка́же | }\end{array}$ & $\begin{array}{l}\text { what dream you saw. He says } \\
\text { that to the Roma. The Roma } \\
\text { says: }\end{array}$ \\
\hline [21-1:37] & 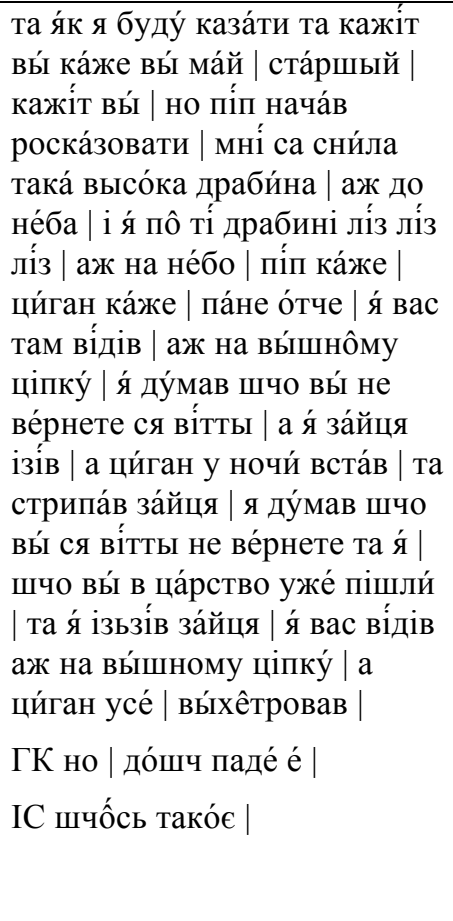 & $\begin{array}{l}\text { how will I tell, you tell first, } \\
\text { you are more important, you } \\
\text { tell. So the priest started telling: } \\
\text { I dreamed, there was such a } \\
\text { high ladder, so that it reached } \\
\text { the sky, and I was climbing this } \\
\text { ladder into the heaven. The } \\
\text { Roma says: Father, I saw you } \\
\text { there on the highest rung of the } \\
\text { ladder, I thought you were not } \\
\text { coming back from there, and I } \\
\text { ate the rabbit. And the Roma } \\
\text { had woken up at night and ate } \\
\text { the rabbit. I thought, he says, } \\
\text { you wouldn't come back from } \\
\text { there and I... thought that you } \\
\text { already went to heaven, and I } \\
\text { ate the rabbit. I saw you on the } \\
\text { highest rung of the ladder. So } \\
\text { the Roma outsmarted the priest. } \\
\text { HK: Yes. See, it is raining. } \\
\text { IS: Something like this. }\end{array}$ \\
\hline [21-1:38] & $\begin{array}{l}|\ldots| \\
\text { ГК є́| } \mid \text { такі є́ | } \\
\text { ІС á | та да́вно бы́ло шчо̂́сь } \\
\text { тако́є } \\
\text { ГК а те̂пе̂́рькы | а те̂пе̂́рь уже́ } \\
\text { май бі́льше | та іду́т по } \\
\text { монастыря́х та те̂пе̂́рькы | a } \\
\text { давно́ | давно́ бы́ло тако́є } \\
\text { шчо помага́ли яко̂́сь | єнны́ } \\
\text { дру́гым | те̂пе̂́рь по́пы } \\
\text { помага́ют | } \\
\text { |...| }\end{array}$ & $\begin{array}{l}\text { [Interviewer: Have you heard, } \\
\text { are there such people that can } \\
\text { see devils and help possessed } \\
\text { people?] } \\
\text { HK: There are such people, yes. } \\
\text { IS: Yes, long ago there was } \\
\text { something like that. } \\
\text { HK: And now... and now } \\
\text { already more often... People go } \\
\text { to monasteries now. And long } \\
\text { ago, people used to help one } \\
\text { another somehow. Now it is the } \\
\text { priests who help. }\end{array}$ \\
\hline
\end{tabular}




\begin{tabular}{|c|c|c|}
\hline $\begin{array}{l}\text { Recording, } \\
\text { minute }\end{array}$ & Text (22) & Translation \\
\hline & $\begin{array}{l}\text { ГК помага́ют | ту́й | бізі́вно у } \\
\text { на́з бы́в | ге юрча́к | но та } \\
\text { ходи́ли | у бо̂ро̂́няву | та́м } \\
\text { бы́в такы́й піп | } \\
\text { ІС мо́нах } \\
\text { ГК мо́нах | по́пы нє́т | тото́ } \\
\text { лиш мона́хы | могли́ помочи́ | } \\
\text { но та пішли́ там | у } \\
\text { монасть́рь | та прика́зовала } \\
\text { уже́ жона́ | }\end{array}$ & $\begin{array}{l}\text { [Interviewer:] Do they? } \\
\text { HK: They do. Here, in our } \\
\text { neigborhood there was one } \\
\text { Yurchak. So they went to } \\
\text { Boronjava, there was such a } \\
\text { priest... } \\
\text { IS: A monk. } \\
\text { HK: A monk. Priests cannot do } \\
\text { that, it is only monks that could } \\
\text { help. So they went there to the } \\
\text { monastery, and the woman told } \\
\text { us, }\end{array}$ \\
\hline [21-1:39] & 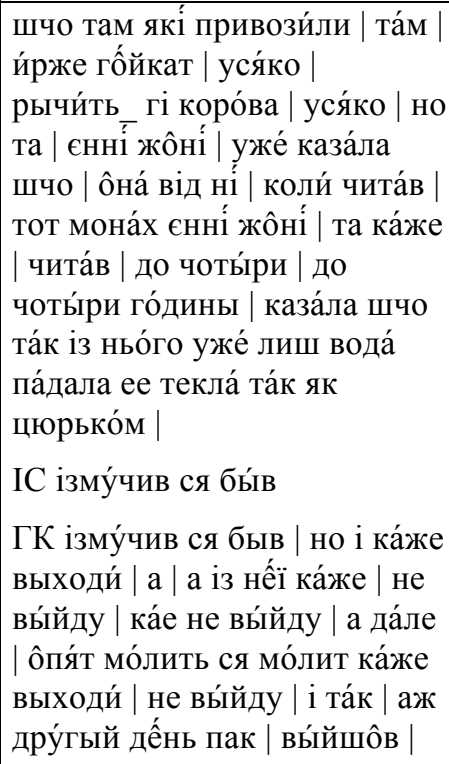 & $\begin{array}{l}\text { that such cases were brought } \\
\text { there, people who neighed as } \\
\text { horses, yelled, mooed as cows, } \\
\text { all sorts. And one woman says, } \\
\text { that monk was reading [prayers] } \\
\text { over a woman until } 4 \text { am [or: } 4 \\
\text { hours in a row?], she said that } \\
\text { he was sweating, streams were } \\
\text { running down his face. } \\
\text { IS: He got exhausted. } \\
\text { HK: He got exhausted. And } \\
\text { then he says: come out! And it } \\
\text { responds from inside her: I am } \\
\text { not coming out! And he is } \\
\text { praying and praying again, and } \\
\text { says: come out! -- I won't! And } \\
\text { so only the next day it came out }\end{array}$ \\
\hline [21-1:40] & 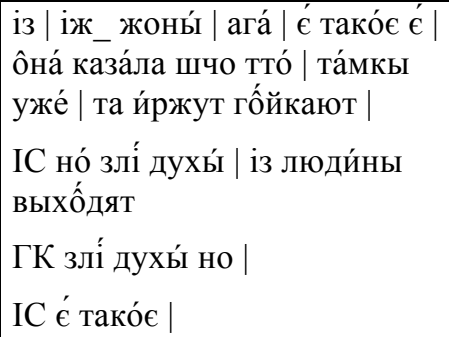 & $\begin{array}{l}\text { from that woman. Yes, such } \\
\text { things happen. She said that } \\
\text { people there neigh and yell. } \\
\text { IS: Yes, evil spirits come out } \\
\text { from a person } \\
\text { HK: Yes, evil spirits. } \\
\text { IS: Such things happen. }\end{array}$ \\
\hline
\end{tabular}


Structure of a Story-Telling Performance Among

Carpatho-Rusyns in Zakarpats'ka Oblast' of Ukraine

\begin{tabular}{|c|c|c|}
\hline $\begin{array}{c}\text { Recording, } \\
\text { minute }\end{array}$ & Text (22) & Translation \\
\hline & $\begin{array}{l}\text { ГК його́ пак ві́тты взя́ли я́ } \\
\text { забы́ла де́ | те̂пе̂́рь із } \\
\text { боิро̂́нявы дру́гый | мона́х | та } \\
\text { | практику́є ся | бо́г зна́є як | } \\
\text { ци | ци бде́ так | та мо́же і бде́ } \\
\text { | молитвы́ | всьо́ молитвы́ | } \\
\text { ІС як він бу́де та тре́ | ма́ти } \\
\text { си́лу } \\
\text { ГК но ай я́к | } \\
\text { |... }\end{array}$ & $\begin{array}{l}\text { HK: He was later transferred } \\
\text { there, I forgot where to. Now } \\
\text { there is another monk from } \\
\text { Boronjava, he is learning that. I } \\
\text { don't know if he will be able to } \\
\text { do it too. But maybe he will. } \\
\text { It's all in prayers. } \\
\text { IS: It depends how he will turn } \\
\text { out. One needs to have strength. } \\
\text { HK: Of course. } \\
\text { [Interviewer: I heard in a } \\
\text { different village that a priest } \\
\text { could see a witch on Easter.] }\end{array}$ \\
\hline [21-1:41] & 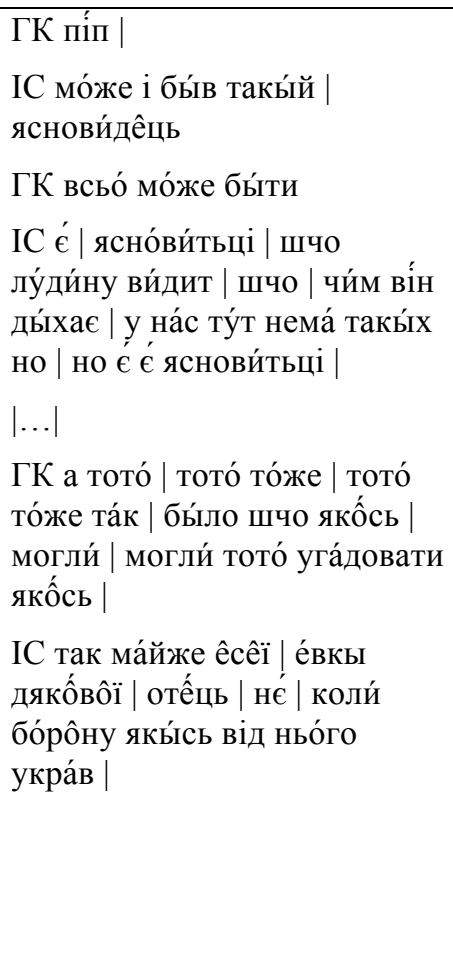 & $\begin{array}{l}\text { HK: A priest? } \\
\text { IS: Maybe there was such a } \\
\text { priest. A clairvoyant. } \\
\text { HK: Maybe. } \\
\text { IS: There are clairvoyants that } \\
\text { can see a person, what he } \\
\text { breaths with. We don't have } \\
\text { such people here, but there are } \\
\text { clairvoyants. } \\
\text { [Interviewer: Maybe there were } \\
\text { such people who could divine } \\
\text { who stole something and where } \\
\text { the stolen thing was.] } \\
\text { HK: Oh, that, that also, that also } \\
\text { so... It was that somehow they } \\
\text { could... they could divine that } \\
\text { somehow. } \\
\text { IS: And maybe the father of that } \\
\text { Evka Diakova, no? when } \\
\text { someone stole a harrow from } \\
\text { him. }\end{array}$ \\
\hline [21-1:42] & ГК кого́ & HK: What? \\
\hline
\end{tabular}




\begin{tabular}{|c|c|c|}
\hline $\begin{array}{c}\text { Recording, } \\
\text { minute }\end{array}$ & Text (22) & Translation \\
\hline & 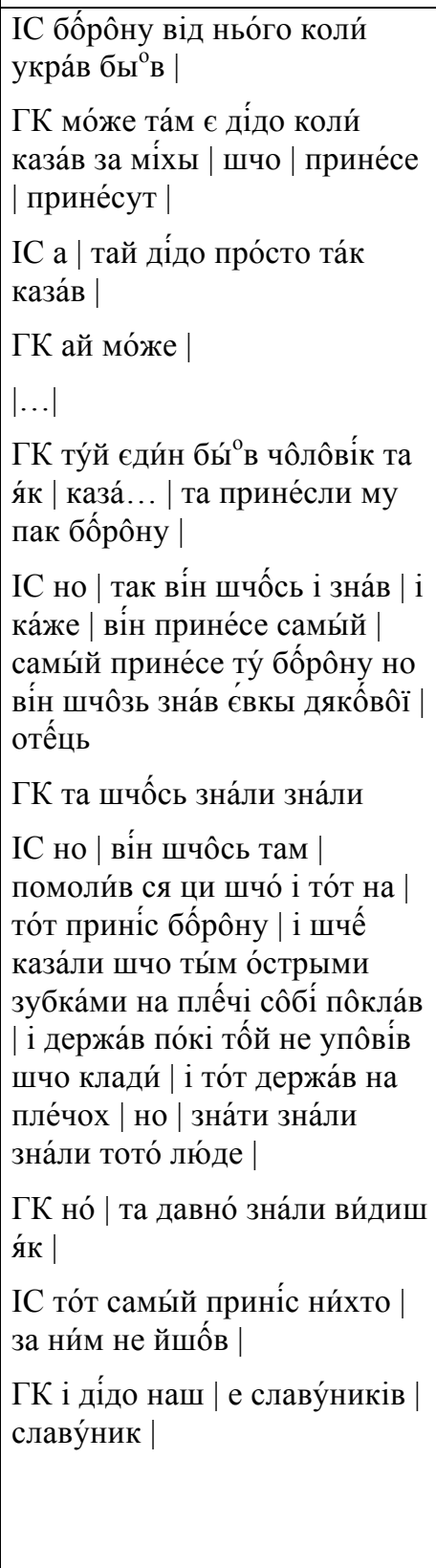 & $\begin{array}{l}\text { IS: When someone stole a } \\
\text { harrow from him. } \\
\text { HK: Maybe there is an old man } \\
\text { who told about the sacks that he } \\
\text { will bring... they will bring... } \\
\text { IS: No, the old man did not } \\
\text { mean that. } \\
\text { HK: But maybe... } \\
\text { [Interviewer: What?] } \\
\text { HK: There was one man here, } \\
\text { and as he said, they later } \\
\text { brought it to him. } \\
\text { IS. Yes. He knew something. } \\
\text { And he says: the guy will bring } \\
\text { it himself, he will himself bring } \\
\text { that harrow. He knew } \\
\text { something, this father of Evka } \\
\text { D'akova. } \\
\text { HK: Yes, he really knew } \\
\text { something. } \\
\text { IS: Yes. He somehow... } \\
\text { whether prayed or what, and } \\
\text { that guy, he brought back the } \\
\text { harrow, and people also said } \\
\text { that he put it on his back these } \\
\text { sharp nails down, and he was } \\
\text { holding it untill the man told } \\
\text { him to put it down, he was } \\
\text { holding it on his shoulders. Yes. } \\
\text { People used to know something. } \\
\text { HK: Yes, long ago, they knew, } \\
\text { see. } \\
\text { IS: That guy brought it back by } \\
\text { himself, no one went after him. } \\
\text { HK: And our old man, } \\
\text { Slavunik. }\end{array}$ \\
\hline
\end{tabular}


Structure of a Story-Telling Performance Among

Carpatho-Rusyns in Zakarpats'ka Oblast' of Ukraine

\begin{tabular}{|c|c|c|}
\hline $\begin{array}{c}\text { Recording, } \\
\text { minute }\end{array}$ & Text (22) & Translation \\
\hline$[21-1: 43]$ & 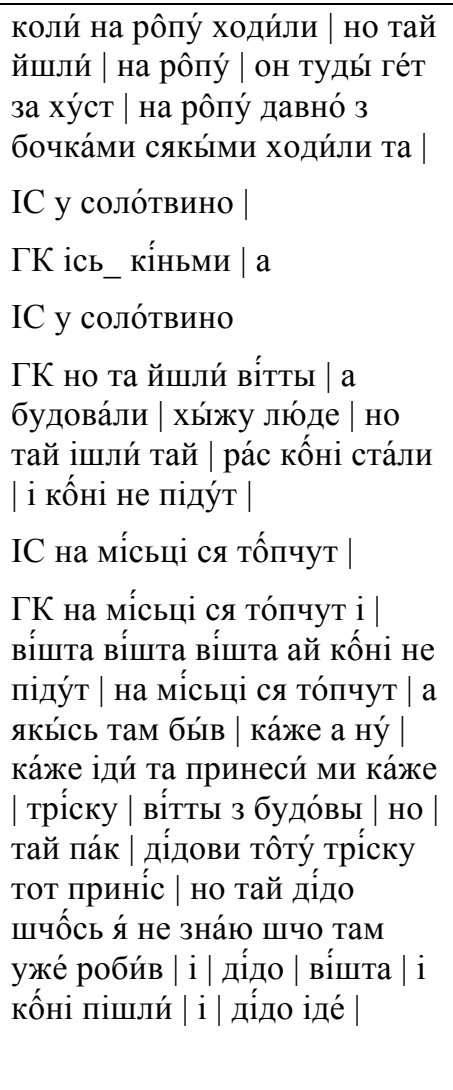 & $\begin{array}{l}\text { When he went to get the brine, } \\
\text { so they were riding there, } \\
\text { beyond Khust. Long ago they } \\
\text { went to get brine, they took } \\
\text { such barrels. } \\
\text { IS: To Solotvyno. } \\
\text { HK: In horse driven carts. } \\
\text { IS: To Solotvyno. } \\
\text { HK: So they went from there, } \\
\text { and people were building a } \\
\text { house, and they were passing } \\
\text { this house, and here, the horses } \\
\text { stopped and wouldn't go. } \\
\text { IS: They were stamping their } \\
\text { feet, but not moving, stamping } \\
\text { in place. And there was such a } \\
\text { man there, and he says, go and } \\
\text { bring me a sliver. From there, } \\
\text { from the building site. And he } \\
\text { brought the old man that sliver, } \\
\text { and the old man did something, } \\
\text { I don't know what he was doing } \\
\text { there, and the old man said: } \\
\text { gee! and the horses started. And } \\
\text { the old man is riding, }\end{array}$ \\
\hline [21-1:44] & 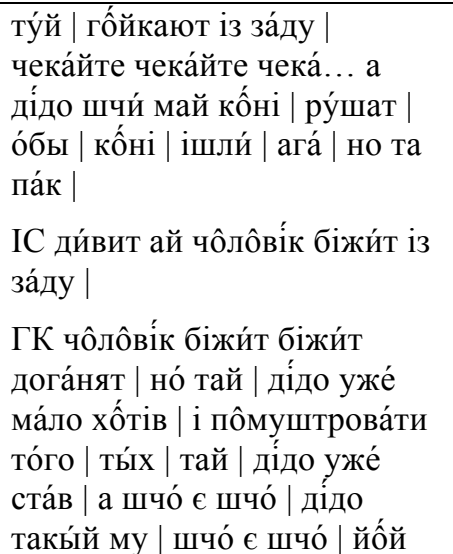 & $\begin{array}{l}\text { and here someone is yelling } \\
\text { from behind: wait, wait, wait! } \\
\text { And the old man makes his } \\
\text { horses ran faster, so that they } \\
\text { ran. And then... } \\
\text { IS: They look, and a man is } \\
\text { running towards them from } \\
\text { behind. } \\
\text { HK: A man is running after } \\
\text { them, and catches up with them. } \\
\text { The old man already wanted to } \\
\text { teach them. So the old man } \\
\text { stopped his horses: what is it? }\end{array}$ \\
\hline
\end{tabular}




\begin{tabular}{|c|c|c|}
\hline $\begin{array}{c}\text { Recording, } \\
\text { minute }\end{array}$ & Text (22) & Translation \\
\hline & 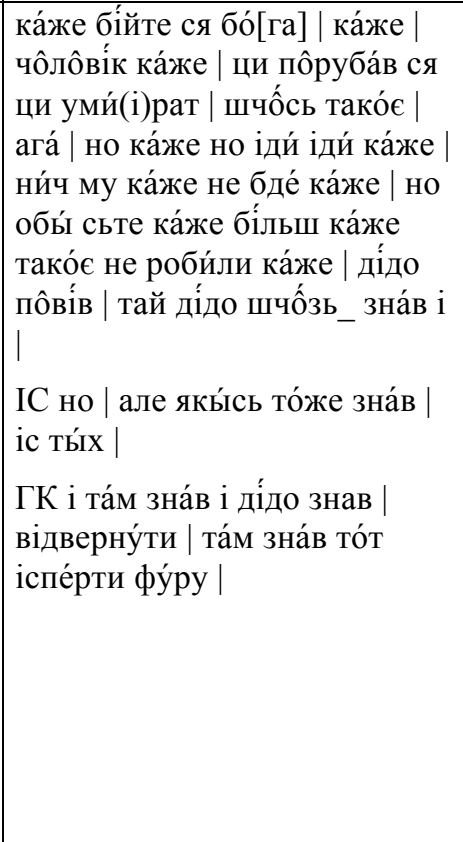 & $\begin{array}{l}\text { that's what the old man asks } \\
\text { him: what? Oh, he says, what } \\
\text { are you doing, don't you fear } \\
\text { God, he says, a man there, } \\
\text { whether he cut himself badly, } \\
\text { whether he is dying, something } \\
\text { like that. Aha. Well, the old } \\
\text { man says, go now, nothing bad } \\
\text { will happen to him, but you } \\
\text { guys don't do that again, he } \\
\text { says. That's what the old man } \\
\text { said. The old man knew } \\
\text { something. } \\
\text { IS: Yes. But someone from } \\
\text { these guys also knew } \\
\text { something. } \\
\text { HK: There, a guy knew } \\
\text { something, and the old man } \\
\text { knew how to undo it. The guy } \\
\text { there knew how to stop the cart, }\end{array}$ \\
\hline \begin{tabular}{|l} 
[21-1:45] \\
\end{tabular} & 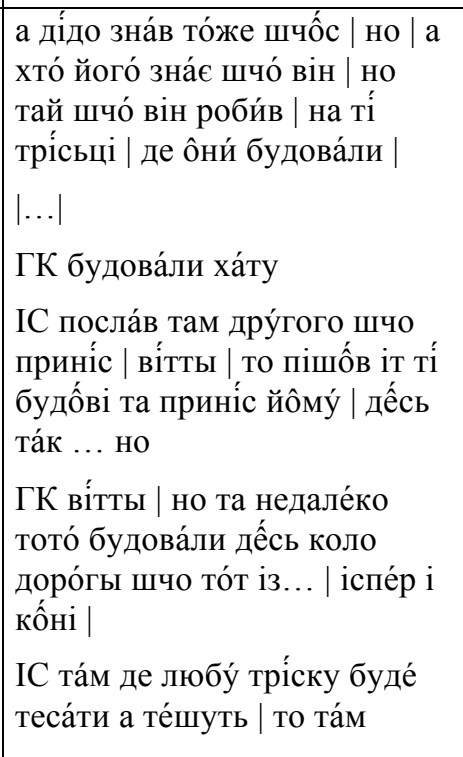 & $\begin{array}{l}\text { and the old man knew also } \\
\text { something. And who knows } \\
\text { what he... and what he did with } \\
\text { this sliver from the building } \\
\text { site. } \\
\text { [Interviewer: I just didn't } \\
\text { understand from where he got } \\
\text { this sliver.] } \\
\text { HK: They were building a } \\
\text { house. } \\
\text { IS: The old man sent another } \\
\text { person to bring from there... } \\
\text { That person went to this } \\
\text { building site and brought him... } \\
\text { Something like that. } \\
\text { HK: From there. So they were } \\
\text { building somewhere near the }\end{array}$ \\
\hline
\end{tabular}


Structure of a Story-Telling Performance Among

Carpatho-Rusyns in Zakarpats'ka Oblast' of Ukraine

\begin{tabular}{|c|c|c|}
\hline $\begin{array}{c}\text { Recording, } \\
\text { minute }\end{array}$ & Text (22) & Translation \\
\hline & 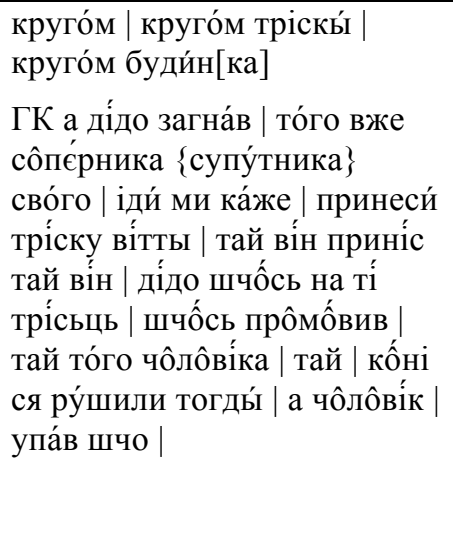 & $\begin{array}{l}\text { road so that that guy could stop } \\
\text { the old man's horses. } \\
\text { IS: There, any old sliver, they } \\
\text { hew wood, and all around there } \\
\text { are slivers, around the house. } \\
\text { HK: And the old man sent that } \\
\text { person who was going with } \\
\text { him, go, he says, bring me a } \\
\text { sliver from there, and he did, } \\
\text { and the old man said something } \\
\text { on this sliver, and that guy... } \\
\text { horses could move then, and the } \\
\text { guy, either fell or what, }\end{array}$ \\
\hline [21-1:46] & 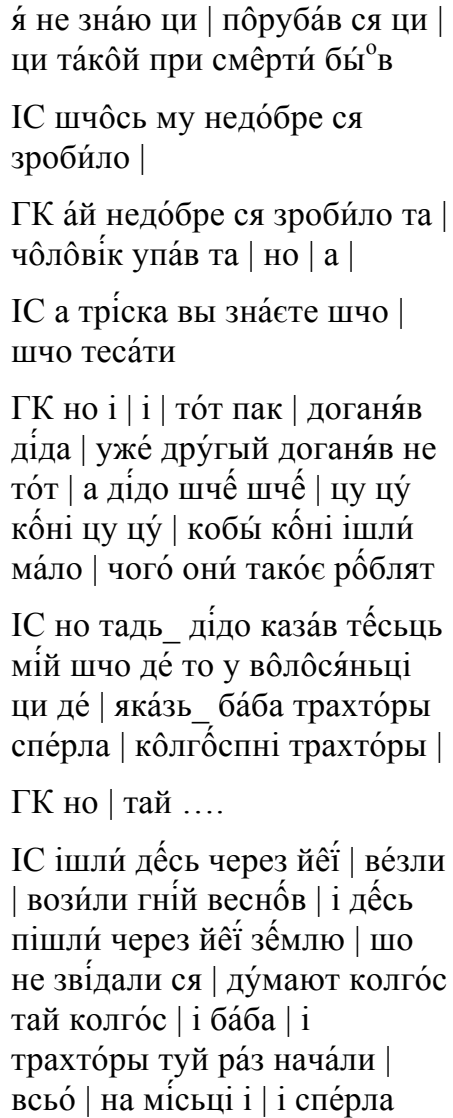 & $\begin{array}{l}\text { I don't know if he cut himself, } \\
\text { or was dying. } \\
\text { IS: Something bad happened to } \\
\text { him. /[he fainted] } \\
\text { HK: yes, something bad } \\
\text { happened to him. /[he fainted], } \\
\text { and he fell down, yes. } \\
\text { IS: And do you know what a } \\
\text { sliver is? When they hew wood. } \\
\text { HK: yes, and... he who then ran } \\
\text { after the old man, it was another } \\
\text { guy, not that guy. And the old } \\
\text { man still more ... gee gee } \\
\text { horses, so that horses go a bit. } \\
\text { Why would they do that. } \\
\text { IS: And the old man said, my } \\
\text { father-in-law, that somewhere } \\
\text { in Volosianka, or somewhere, a } \\
\text { woman stopped tractors, } \\
\text { tractors from a collective farm. } \\
\text { HK: Yes [unclear] } \\
\text { IS: They were going through } \\
\text { her... they were carrying } \\
\text { manure in spring and } \\
\text { somewhere went through her }\end{array}$ \\
\hline
\end{tabular}




\begin{tabular}{|c|c|c|}
\hline $\begin{array}{l}\text { Recording, } \\
\text { minute }\end{array}$ & Text (22) & Translation \\
\hline & $\begin{array}{l}\text { трахто́ры | і да́льше | ходи́ли | } \\
\text { ту́ ба́бу проси́ти | шчобы } \\
\text { пусти́ла тото́ | трахто́ры но | }\end{array}$ & $\begin{array}{l}\text { land, and did not ask } \\
\text { permission. They think, it is } \\
\text { collective farm, after all. And } \\
\text { the woman... And the tractors } \\
\text { at once started ... in one place. } \\
\text { So she stopped the tractors. And } \\
\text { later they would go to that } \\
\text { woman to ask her to let tractors } \\
\text { go. }\end{array}$ \\
\hline [21-1:47] & 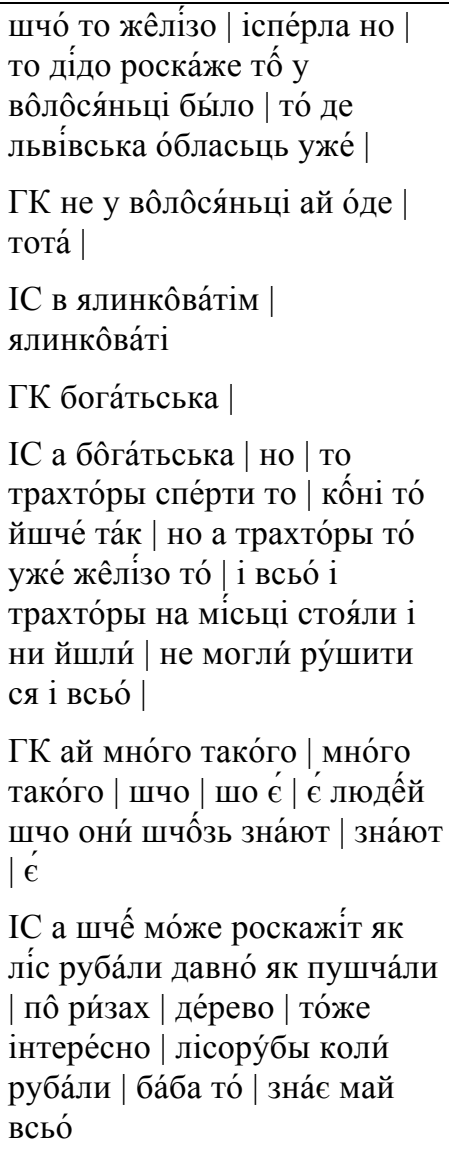 & $\begin{array}{l}\text { It is iron, and she stopped them. } \\
\text { That the old man can tell, it was } \\
\text { in Volosianka, it is already the } \\
\text { Lviv region. } \\
\text { HK: Not in Volosianka but } \\
\text { here, that... } \\
\text { IS: In Ialynkovate } \\
\text { HK: Bohatska. } \\
\text { IS: Ah, Bohatska. Well. To stop } \\
\text { tractors, it is something. To stop } \\
\text { horses, it is not that difficult, } \\
\text { but tractors are iron. And all the } \\
\text { tractors were standing in one } \\
\text { place and did not go, could not } \\
\text { move, and that was it. } \\
\text { HK: But there are many such } \\
\text { things, many such things are. } \\
\text { There are people who know } \\
\text { something, there are. } \\
\text { IS: And also maybe you will } \\
\text { tell as they cut wood long ago } \\
\text { and let it down by such troughs, } \\
\text { wood, that is also interesting, } \\
\text { when the woodcutters cut wood. } \\
\text { Our old woman knows that. }\end{array}$ \\
\hline [21-1:48] & $\begin{array}{l}\text { ‥ ГК с то́го бо́́ку жоло́бы | i } \\
\text { с сьо́го бо̂́ку де́рево і с то́го }\end{array}$ & $\begin{array}{l}\text { HK: There are troughs on that } \\
\text { side, wood from that side, wood }\end{array}$ \\
\hline
\end{tabular}


Structure of a Story-Telling Performance Among

Carpatho-Rusyns in Zakarpats'ka Oblast' of Ukraine

\begin{tabular}{|c|c|c|}
\hline $\begin{array}{c}\text { Recording, } \\
\text { minute }\end{array}$ & Text (22) & Translation \\
\hline & 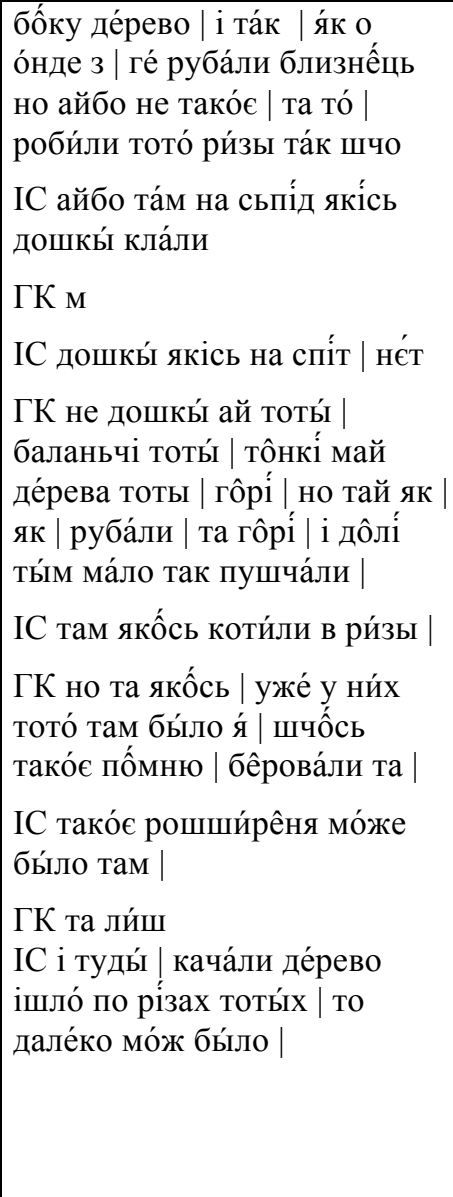 & $\begin{array}{l}\text { from this side, and like this, as } \\
\text { here. So they were cutting } \\
\text { wood, on the Twin mountain, } \\
\text { but not like this, and they were } \\
\text { making such troughs, so that... } \\
\text { IS: But they put some boards } \\
\text { underneath. } \\
\text { HK: What? } \\
\text { IS: They put some boards } \\
\text { underneath, no? } \\
\text { HK: Not boards but such... } \\
\text { small pieces of wood, these thin } \\
\text { trunks. Up there. When they cut } \\
\text { wood up in the mountains, they } \\
\text { let it go down these troughs. } \\
\text { IS: They put it somehow in } \\
\text { these troughs. } \\
\text { HK: Yes, they had this up there. } \\
\text { I remember something like that. } \\
\text { They were strong. } \\
\text { IS: Maybe there was such wide } \\
\text { place there. } \\
\text { HK: Should be. } \\
\text { IS: And they rolled the wood } \\
\text { there, and it went down these } \\
\text { troughs, it could go far. }\end{array}$ \\
\hline [21-1:49] & $\begin{array}{l}\text { ГК дале́ко дале́ко йоิй та } \\
\text { пра́вда шчо там | } \\
\text { ІС куды́ хоิті́ли цапи́нами } \\
\text { ГК го́споди | тай | я́ коли́ } \\
\text { бы́ла у то́му | о́нде у } \\
\text { при́сло̂пі | } \\
\text { IC айбо сіда́йте бли́же бо | не } \\
\text { бде́ чу́ти } \\
\text { ГК а вы́ пи́шете | у сі́янці | но }\end{array}$ & $\begin{array}{l}\text { HK: Yes, very far, that's right. } \\
\text { IS: They pushed it where they } \\
\text { wanted with hooks. } \\
\text { HK. Oh. And when I was there, } \\
\text { in Pryslip... } \\
\text { IS: Move closer, or you won't } \\
\text { hear. } \\
\text { HK: And you are writing? In } \\
\text { the nursery where they grow }\end{array}$ \\
\hline
\end{tabular}




\begin{tabular}{|c|c|c|}
\hline Recording, & Text (22) & Translation \\
\hline & 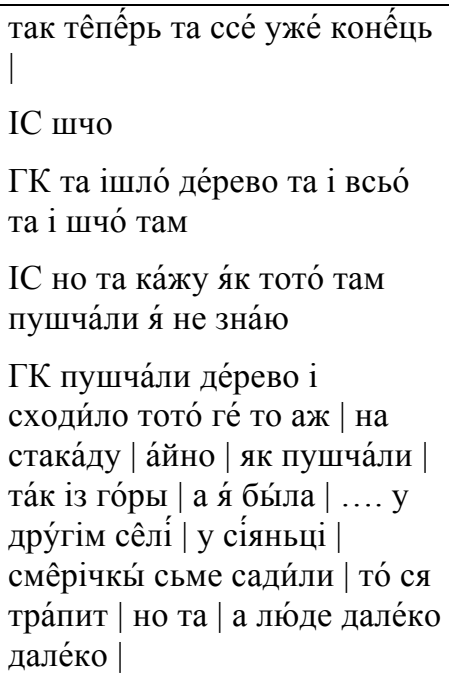 & $\begin{array}{l}\text { young spruces. Well, now it is } \\
\text { the end already. } \\
\text { IS: What? } \\
\text { HK: The wood was going, and } \\
\text { that's it. } \\
\text { IS: Yes, and I say I don't know } \\
\text { how they let it go down there. } \\
\text { HK: They let the wood go down } \\
\text { and it went down. The let it } \\
\text { down from the mountain. And I } \\
\text { was in a different village, in a } \\
\text { nursery, we were planting } \\
\text { spruces. That happens. And } \\
\text { people far away }\end{array}$ \\
\hline [21-1:50] & 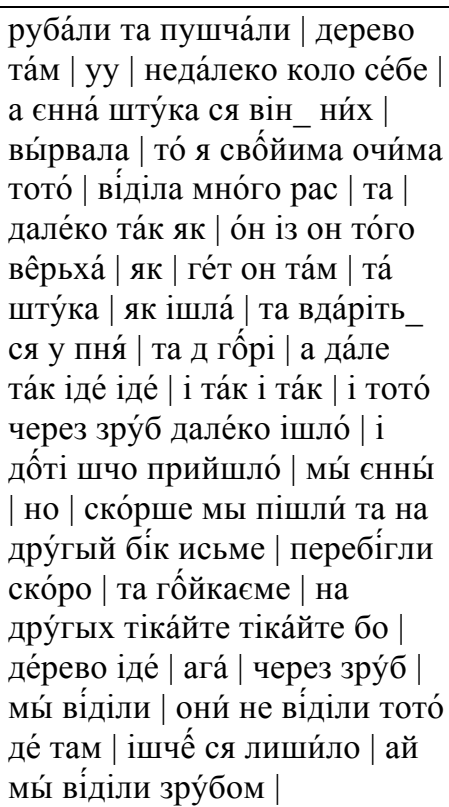 & $\begin{array}{l}\text { were cutting wood and letting it } \\
\text { go down. The wood. Not far } \\
\text { from themselves. And one log } \\
\text { got away from them. I saw it } \\
\text { with my own eyes, many times. } \\
\text { And it was far, like from that } \\
\text { mountain over there. This log, } \\
\text { as it went down, it hit against a } \\
\text { stump and went up, and then } \\
\text { went down like this, through the } \\
\text { trough (?). And until it came... } \\
\text { we... we went before that and } \\
\text { went to the other side, run there } \\
\text { real fast, and we are yelling to } \\
\text { others: run, run, because a log is } \\
\text { going down, across the } \\
\text { trough(?). We saw it and they } \\
\text { did not see it. It was still there, } \\
\text { and we saw how it went down } \\
\text { the trough. }\end{array}$ \\
\hline [21-1:51] & $\begin{array}{l}\text { i прийшло́ і пак | уда́рило } \\
\text { было но шчо пак ї зві́тты } \\
\text { прине́сли | я́ пак забы́ла | пак } \\
\text { у бо́лници бы́ла | шчо | }\end{array}$ & $\begin{array}{l}\text { And then it hit, and then they } \\
\text { brought her from there. I forgot } \\
\text { how it was. She was in a } \\
\text { hospital then, it did not kill her. }\end{array}$ \\
\hline
\end{tabular}


Structure of a Story-Telling Performance Among

Carpatho-Rusyns in Zakarpats'ka Oblast' of Ukraine

\begin{tabular}{|c|c|c|}
\hline $\begin{array}{l}\text { Recording, } \\
\text { minute }\end{array}$ & Text (22) & Translation \\
\hline & 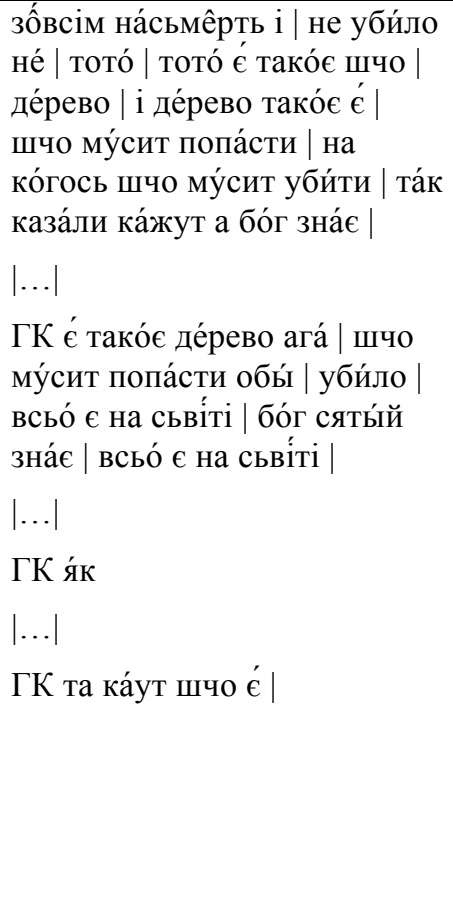 & $\begin{array}{l}\text { That happens that a tree, there is } \\
\text { such a tree that must hit a } \\
\text { person, that it must kill } \\
\text { someone. That's what people } \\
\text { say, God knows if it is right. } \\
\text { [Interviewer: That there is such } \\
\text { a tree?] } \\
\text { HK: There is such a tree, yes, } \\
\text { that must hit someone and kill. } \\
\text { There is everything in the } \\
\text { world. Holy God knows. There } \\
\text { is everything in the world. } \\
\text { [Interviewer: Does it happen } \\
\text { that something makes a person } \\
\text { gets lost in the forest?] } \\
\text { HK: What? } \\
\text { [Interviewer: Does it happen } \\
\text { that something leads a person } \\
\text { astray in the woods?] } \\
\text { HK: People say it happens. }\end{array}$ \\
\hline [21-1:52] & 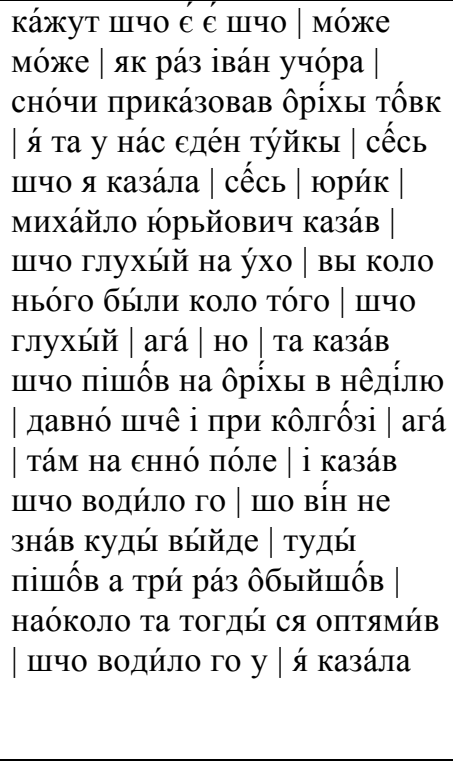 & $\begin{array}{l}\text { They say that there is something } \\
\text { that... Yes, it happens. Ivan just } \\
\text { told last night, when he was } \\
\text { grinding walnuts. There is one } \\
\text { guy here, the one I told you, this } \\
\text { one, Yurik, Myhailo Iurievych } \\
\text { told, the one who is deaf in one } \\
\text { ear. You were to his place, the } \\
\text { one who is deaf. Yes, so he said } \\
\text { that he went to gather nuts once } \\
\text { on a Sunday, long ago, at the } \\
\text { time of collective farms. Yes. } \\
\text { There he went to a field, and he } \\
\text { said something made him lose } \\
\text { his way, so that he did not know } \\
\text { where he was going. He went } \\
\text { there, and went three times } \\
\text { around, and then he came to } \\
\text { himself. Something led him }\end{array}$ \\
\hline
\end{tabular}




\begin{tabular}{|c|c|c|}
\hline Recording, & Text (22) & Translation \\
\hline & $\begin{array}{l}\text { шчо за то́ шчо в не̂ді́лю йшо́́в } \\
\text { | при слу́жбі́ | }\end{array}$ & $\begin{array}{l}\text { astray. I said it was because he } \\
\text { went on Sunday at the time of } \\
\text { the church service. }\end{array}$ \\
\hline [21-1:53] & 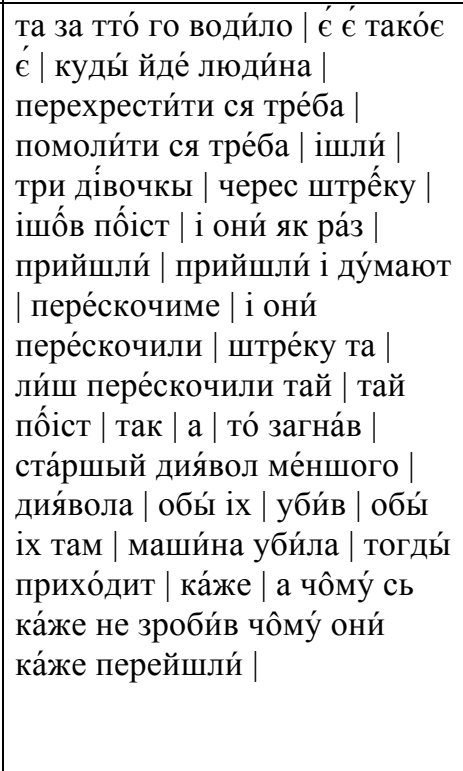 & $\begin{array}{l}\text { And because of that something } \\
\text { led him astray. There is } \\
\text { something like this. If a person } \\
\text { goes somewhere, one needs to } \\
\text { make a sign of the cross over } \\
\text { oneself, and pray. Once three } \\
\text { girls crossed a railway. A train } \\
\text { was coming, and they came to } \\
\text { the rails and thought: we'll } \\
\text { jump it. And they jumped it and } \\
\text { as soon as they were on the } \\
\text { other side, the train came. And } \\
\text { a chief devil sent a younger } \\
\text { devil so that he should kill } \\
\text { them, so that they get run over } \\
\text { by the train. So the devil comes } \\
\text { back and that one says: why } \\
\text { didn't you do that, how come } \\
\text { they could cross safely? }\end{array}$ \\
\hline [21-1:54] & 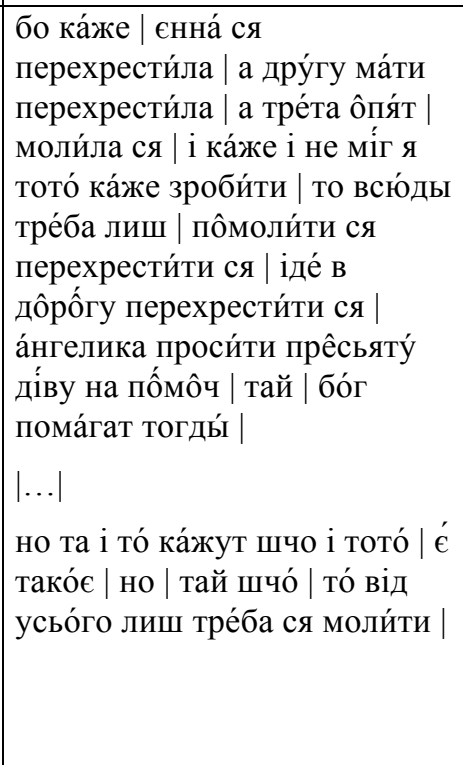 & $\begin{array}{l}\text { And this one answers: because } \\
\text { one made a sign of the cross } \\
\text { over herself, and the other, her } \\
\text { mother crossed her, and the } \\
\text { third one prayed. And, he says, } \\
\text { I could not do that. Everywhere } \\
\text { you go, you need to pray and } \\
\text { make a sign of the cross, if you } \\
\text { go somewhere, and ask an } \\
\text { angel, and the Holy Virgin to } \\
\text { help you. And then God helps } \\
\text { you. } \\
\text { [Interviewer: Does it happen } \\
\text { that a person sees something at } \\
\text { night?] } \\
\text { HK: Yes, people say that also } \\
\text { happened. And what, you just } \\
\text { need to pray against everything, }\end{array}$ \\
\hline
\end{tabular}


Structure of a Story-Telling Performance Among

Carpatho-Rusyns in Zakarpats'ka Oblast' of Ukraine

\begin{tabular}{|c|c|c|}
\hline $\begin{array}{c}\text { Recording, } \\
\text { minute }\end{array}$ & Text (22) & Translation \\
\hline [21-1:55] & $\begin{array}{l}\text { від усьо́го | [при]ви́дить ся і | } \\
\text { ся бойи́т та моли́ти ся тай | } \\
\text { тай тото́ яко̂́сь | прохо́дит } \\
\text { бо́гочко | хорони́т | люди́ну | } \\
\text { як ка́жут | без бо́га й не до } \\
\text { поро́га | } \\
|\ldots| \\
\text { у лі́ci | та я тото́ то́же чу́ла но } \\
\text { а я́ зна́ю ци то́ мо́же бы́ти | } \\
\text { шчо то́ а́йно у лі́сі | чека́йте | } \\
\text { шчо̂́сь то шче̂́ хо̂́тіла каза́ти | }\end{array}$ & $\begin{array}{l}\text { against everything. It can show } \\
\text { itself to you and... one is afraid, } \\
\text { and one needs to pray, and that } \\
\text { thing somehow disappears. God } \\
\text { protects a person. So they say, } \\
\text { without God you cannot go } \\
\text { even as far as a threshold. } \\
\text { [Interviewer: And people say, } \\
\text { something one can hear music } \\
\text { in the woods?] } \\
\text { HK: In the woods? I also heard } \\
\text { that, but I don't know whether it } \\
\text { can be... what that is... Yes, in } \\
\text { the woods... Wait, what was it } \\
\text { that I wanted to say? }\end{array}$ \\
\hline [21-1:56] & 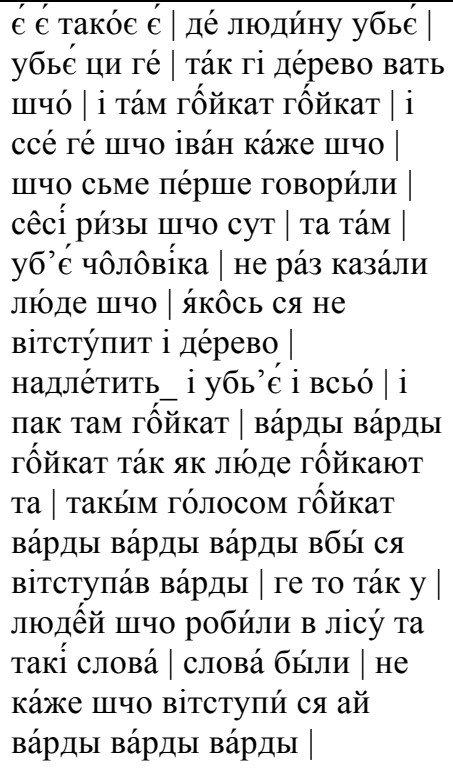 & $\begin{array}{l}\text { Yes, there are such things. } \\
\text { Where a person gets killed, so } \\
\text { as, for example, a tree kills a } \\
\text { person, there something shouts. } \\
\text { And that is, what Ivan said, that } \\
\text { we just talked about, that there } \\
\text { are these troughs, and there, } \\
\text { people said many times that, if } \\
\text { one does not move over and a } \\
\text { tree goes down and kills him, } \\
\text { then later it shouts there: vardy } \\
\text { vardy! It shouts like people } \\
\text { shout, it says vardy vardy, so } \\
\text { that one gets out of the way. } \\
\text { That is, people who worked in } \\
\text { the woods, they had such } \\
\text { words, they wouldn't say “get } \\
\text { out of the way", but vardy } \\
\text { vardy. }\end{array}$ \\
\hline [21-1:57] & $\mid \begin{array}{l}|\ldots| \\
\text { із вівця́ми } \mid \\
|\ldots|\end{array}$ & $\begin{array}{l}\text { [Interviewer: And when people } \\
\text { go herding sheep, do they see } \\
\text { something there?] } \\
\text { HK: Herding sheep? }\end{array}$ \\
\hline
\end{tabular}




\begin{tabular}{|c|c|c|}
\hline $\begin{array}{c}\text { Recording, } \\
\text { minute }\end{array}$ & Text (22) & Translation \\
\hline & $\begin{array}{l}\text { я́ шчо̂сь не чу́ла | обь́ вівчарі́ } \\
\text { тото́ каза́ли | ци мо́же тако́є } \\
\text { бы́ти | шчо̂́сь | не зна́ю | } \\
|\ldots| \\
\text { як } \\
|\ldots| \\
\text { а́нгел | } \\
|\ldots|\end{array}$ & $\begin{array}{l}\text { [Interviewer: When they stay } \\
\text { there.] } \\
\text { HK: I haven't heard shepherds } \\
\text { say anything like that, whether } \\
\text { such things happen. I don't } \\
\text { know. } \\
\text { [Interviewer: And does it } \\
\text { happen that people see } \\
\text { something in dreams?] } \\
\text { HK: What? } \\
\text { [Interviewer: Say, they see an } \\
\text { angel...] } \\
\text { HK: An angel? } \\
\text { [Interviewer: Or something like } \\
\text { this. Or a person who has died.] }\end{array}$ \\
\hline \begin{tabular}{|l|}
$21-1: 58]$ \\
\end{tabular} & 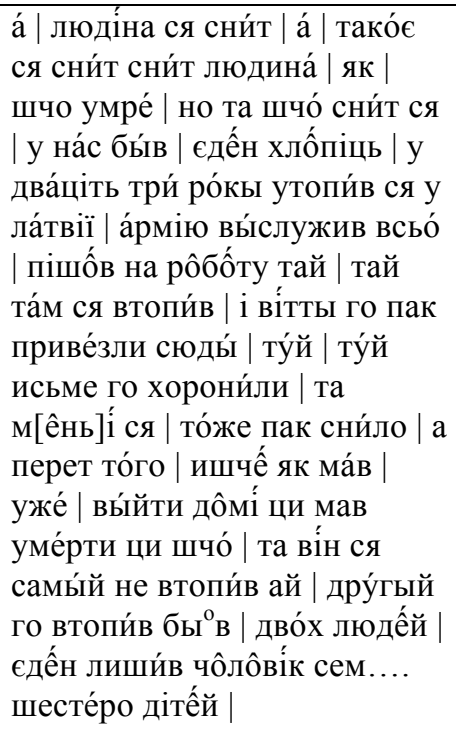 & $\begin{array}{l}\text { HK: Yes, one can see a [dead] } \\
\text { person in a dream. Such things } \\
\text { come in a dream, people who } \\
\text { have died do appear in a dream. } \\
\text { We had one son, and when he } \\
\text { was twenty-three, he drowned } \\
\text { in Latvia. He finished his army } \\
\text { service, started working there, } \\
\text { and there he drowned. And they } \\
\text { brought his body from there } \\
\text { here. We buried him here. And I } \\
\text { had a dream. Even before, when } \\
\text { he had to come home, or had to } \\
\text { die, or what. But he did not } \\
\text { drown by himself, another } \\
\text { person made him and another } \\
\text { guy drown. That guy left } \\
\text { seven... six chilren behind, }\end{array}$ \\
\hline \begin{tabular}{|l} 
[21-1:59] \\
\end{tabular} & $\begin{array}{l}\text { шчо утопи́в ся | то́т прі́гнуев } \\
\text { \{ско́чив\} | як они́ сі́ли | де̂́сь | } \\
\text { ма́ло тото́ | де̂́сь | уве́зли ся } \\
\text { на ло̂́цьці | та они́ два сі́ли | } \\
\text { на́ш | хло̂́пе̂ць тай | той то́т }\end{array}$ & $\begin{array}{l}\text { the guy who got drowned. And } \\
\text { this person jumped, after they } \\
\text { sat... They went somewhere in } \\
\text { a boat, and they two were } \\
\text { sitting there, our son and that }\end{array}$ \\
\hline
\end{tabular}


Carpatho-Rusyns in Zakarpats'ka Oblast' of Ukraine

\begin{tabular}{|c|c|c|}
\hline $\begin{array}{c}\text { Recording, } \\
\text { minute }\end{array}$ & Text (22) & Translation \\
\hline & 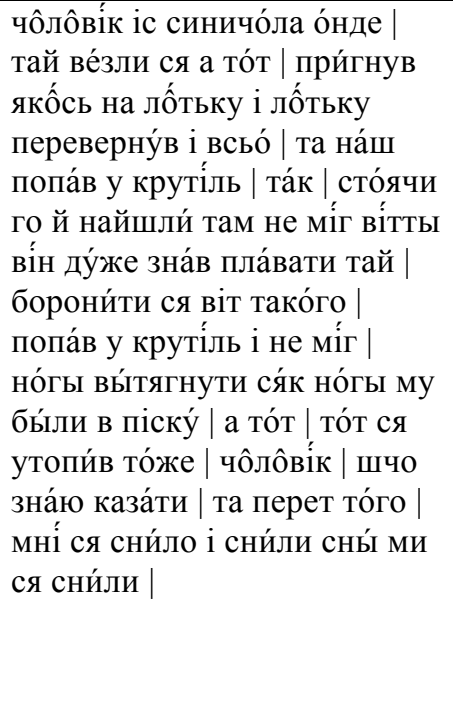 & $\begin{array}{l}\text { man from Synychiv, they were } \\
\text { in the boat, and this guy jumped } \\
\text { somehow in the boat and turned } \\
\text { the boat over, and that was it. } \\
\text { And our son got into a } \\
\text { whirlpool like this, standing. } \\
\text { Because they found him there, } \\
\text { he could not get out from there. } \\
\text { He had known how to swim, } \\
\text { and how to protect himself from } \\
\text { such things, but he got into a } \\
\text { whirlpool and coud not get his } \\
\text { feet out of there, and his feet } \\
\text { were in the sand. And that other } \\
\text { guy also drowned. I don't know } \\
\text { much about that. And before } \\
\text { that, I saw a dream, I saw } \\
\text { several dreams. }\end{array}$ \\
\hline [21-2:00] & 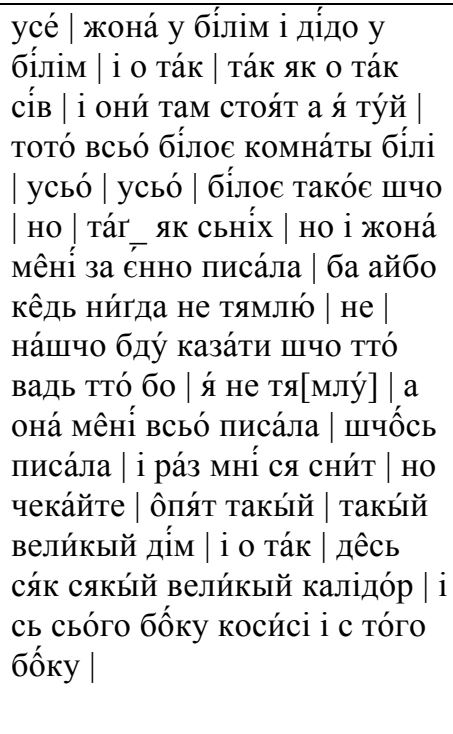 & $\begin{array}{l}\text { And it was always, a woman in } \\
\text { white and an old man in white, } \\
\text { and like this, and he were } \\
\text { standing there, and I was here, } \\
\text { and all that was white, and the } \\
\text { rooms were white. Everything } \\
\text { was white as snow. And that } \\
\text { woman was always writing... } \\
\text { But I don't remember, and I } \\
\text { won't say what it was, because I } \\
\text { don't remember. And she was } \\
\text { always writing, writing } \\
\text { something. And once I saw a } \\
\text { dream. Wait, how was it. Again, } \\
\text { there was such a large house, } \\
\text { and such a large hallway. } \\
\text { Flowers on that side and on this } \\
\text { side, }\end{array}$ \\
\hline [21-2:01] & $\begin{array}{l}\text { тото́ всьо́ у коси́цях | ві́тьсі } \\
\text { захі́д | і я́ яко̂́сь | тото́ іду́ іду́ | } \\
\text { туды́ | i | і та́г_ гі бы у дру́гі } \\
\text { ко́мнаті тай і о та́к у ко̂ммнаті } \\
\text { | а/йбо і тото́ | бі́лоє | а та́м о }\end{array}$ & $\begin{array}{l}\text { everything was covered with } \\
\text { flowers. From there, there was } \\
\text { an entrance, and I was walking } \\
\text { there something, into another } \\
\text { room, and in that room }\end{array}$ \\
\hline
\end{tabular}




\begin{tabular}{|c|c|c|}
\hline $\begin{array}{c}\text { Recording, } \\
\text { minute }\end{array}$ & Text (22) & Translation \\
\hline & 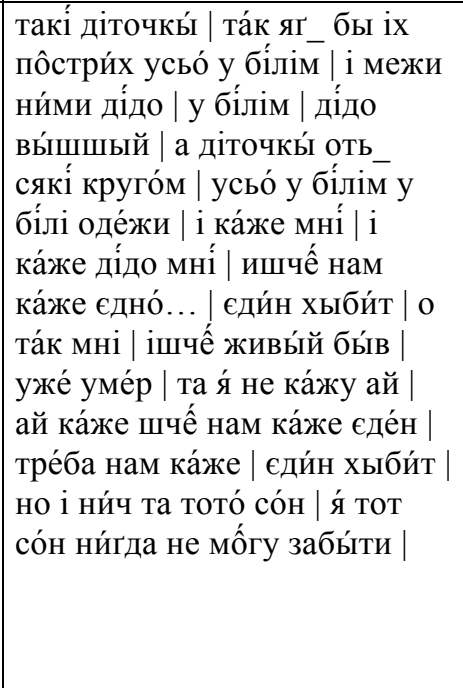 & $\begin{array}{l}\text { everything was also white, and } \\
\text { there were sich kids there, all } \\
\text { the same height, and all in } \\
\text { white, and among them there } \\
\text { was an old man in white. The } \\
\text { old man was taller, and the } \\
\text { children were like this, around } \\
\text { him, all in white, in white } \\
\text { clothes. And he says to me, the } \\
\text { old man says: we are missing } \\
\text { one more, one more. And so I } \\
\text { saw it... he was still alive... or } \\
\text { already died. I don't say } \\
\text { anything. And he says, we need } \\
\text { one more. And that's it, that } \\
\text { was my dream. I cannot forget } \\
\text { this dream. }\end{array}$ \\
\hline [21-2:02] & 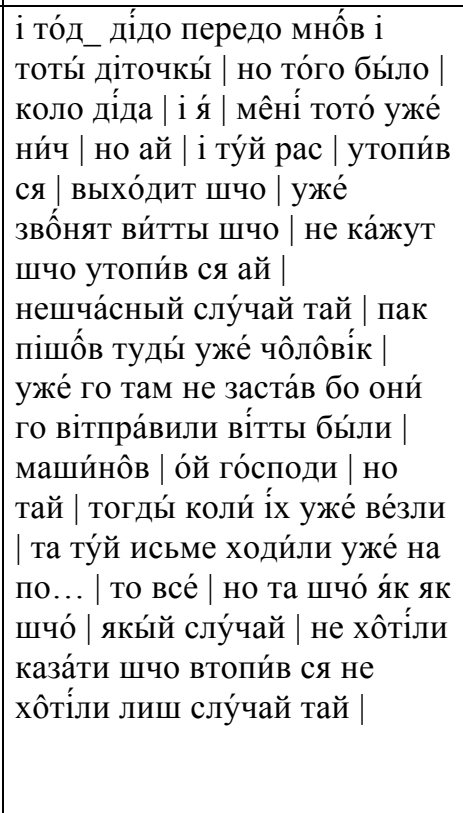 & $\begin{array}{l}\text { And I see this old man in front } \\
\text { of myself, and these children, } \\
\text { around him. And that was it. } \\
\text { And then my son got drowned. } \\
\text { They send me... They called } \\
\text { me from there and said... They } \\
\text { did not say he drowned himself, } \\
\text { they said it was an accident. } \\
\text { And my husband went there, } \\
\text { but he did not find him there } \\
\text { because they already had sent } \\
\text { the body from there in a truck. } \\
\text { Oh my God. And then while } \\
\text { they already sent here these two } \\
\text { bodies, we went to ask diviners. } \\
\text { And what was it, what kind of } \\
\text { an accident, they did not want } \\
\text { to tell me that he had drowned, } \\
\text { did not tell, just said "an } \\
\text { accident". }\end{array}$ \\
\hline \begin{tabular}{|l}
$21-2: 03]$ \\
\end{tabular} & $\begin{array}{l}\text { поби́ли поби́в ся та ссе́ та } \\
\text { тото́ от | но й ни́ч | i ту́й мні́ } \\
\text { ся уже́ коли́ іх ве́зли доิмі́ | i } \\
\text { чу́й ме̂ні́ ся сни́т | уво льво̂́ві | }\end{array}$ & $\begin{array}{l}\text { Whether he hurt himself, and } \\
\text { this, and that. And I didn't say } \\
\text { anything. And again, I hear in a } \\
\text { dream, "they are in Lviv, in }\end{array}$ \\
\hline
\end{tabular}


Carpatho-Rusyns in Zakarpats'ka Oblast' of Ukraine

\begin{tabular}{|c|c|c|}
\hline $\begin{array}{c}\text { Recording, } \\
\text { minute }\end{array}$ & Text (22) & Translation \\
\hline & $\begin{array}{l}\text { та | у оิльво́ві су́т | і на } \\
\text { де̂́вдь_ го́дин ка́же буду́т } \\
\text { ту́йкы у новосе́лиці | і віділа } \\
\text { м які́ | тото́ тру́ны | та́м шчо } \\
\text { шчі у льво́ві бы́ли | та́м им } \\
\text { ві́діла | які́ тру́ны | і я́ ту́йкы | } \\
\text { уже́ у ня́ ту́й уже́ спля́т | } \\
\text { сестра́ тай с при́слопа } \\
\text { не̂ві́стка | ту́йкы сут | тай } \\
\text { ка́жу | устава́йте ге́т | та ка́жу } \\
\text { | ладіт да́шчо і́сти а шчо́ | } \\
\text { ка́жу на де́́вїдь_ го́дин ка́жу | } \\
\text { ту́й буду́т ка́жу лю́де везу́т } \\
\text { ка́жу | не́ поби́тых ка́жу ай } \\
\text { мертвы́х ка́жу дво́х ка́жу } \\
\text { везу́т | они́ нача́ли у дві́ на } \\
\text { ме́не | }\end{array}$ & $\begin{array}{l}\text { Lviv, and they will be here at } \\
\text { nine o'clock, here in } \\
\text { Novoselytsia". And I saw the } \\
\text { coffins, when they still were in } \\
\text { Lviv. I saw them in a dream, } \\
\text { what the coffins looked like. } \\
\text { And here, I had a sister in my } \\
\text { house and a relative from } \\
\text { Pryslip, they were here, and I } \\
\text { said, get up, and, I said, make } \\
\text { something to eat, because, I say, } \\
\text { at nine o'clock there will be } \\
\text { people here, they are bringing } \\
\text { not the injured people, but dead } \\
\text { people, I say, two of them. They } \\
\text { both started saying, }\end{array}$ \\
\hline [21-2:04] & 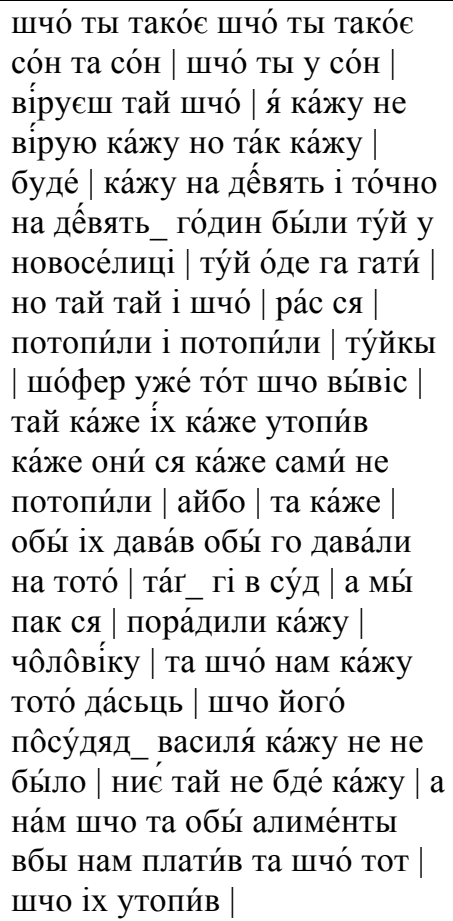 & $\begin{array}{l}\text { what are you talking about, it } \\
\text { was a dream, do you really } \\
\text { believe in a dream. I say, I don't } \\
\text { believe, but it will be like that, } \\
\text { at nine o'clock. And exactly at } \\
\text { nine o'clock they were here in } \\
\text { Novoselytsia, there on the } \\
\text { bridge. And so what. They got } \\
\text { drowned. Here, the driver who } \\
\text { brought the bodies here, he said, } \\
\text { that one made them drown, they } \\
\text { had not drowned by themselves. } \\
\text { And he said, that guy should be } \\
\text { sued. And we talked about this, } \\
\text { and I said to my husband: what } \\
\text { use will it be to us that that guy } \\
\text { will be in court? Vasyl is dead, } \\
\text { and why we need the money } \\
\text { that the one who made them } \\
\text { drown should pay us. }\end{array}$ \\
\hline
\end{tabular}




\begin{tabular}{|c|c|c|}
\hline $\begin{array}{c}\text { Recording, } \\
\text { minute }\end{array}$ & Text (22) & Translation \\
\hline \begin{tabular}{|l} 
[21-2:05] \\
\end{tabular} & 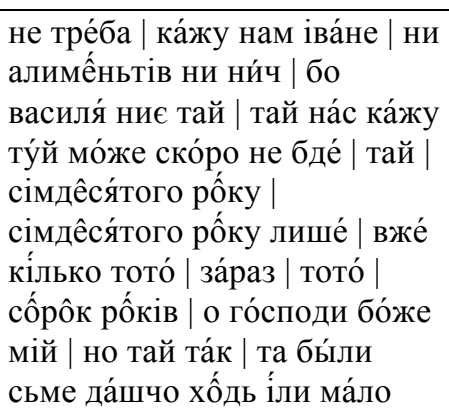 & $\begin{array}{l}\text { Ivan, I say, we don't need this } \\
\text { money or anything, because } \\
\text { Vasyl is dead, and we will } \\
\text { probably be dead soon too. It } \\
\text { was in } 1970, \text { in } 1970 . \text { How long } \\
\text { ago was it? Forty years ago. Oh } \\
\text { my God. Well it was like that. } \\
\text { Will you come and eat } \\
\text { something? }\end{array}$ \\
\hline [22-00] & 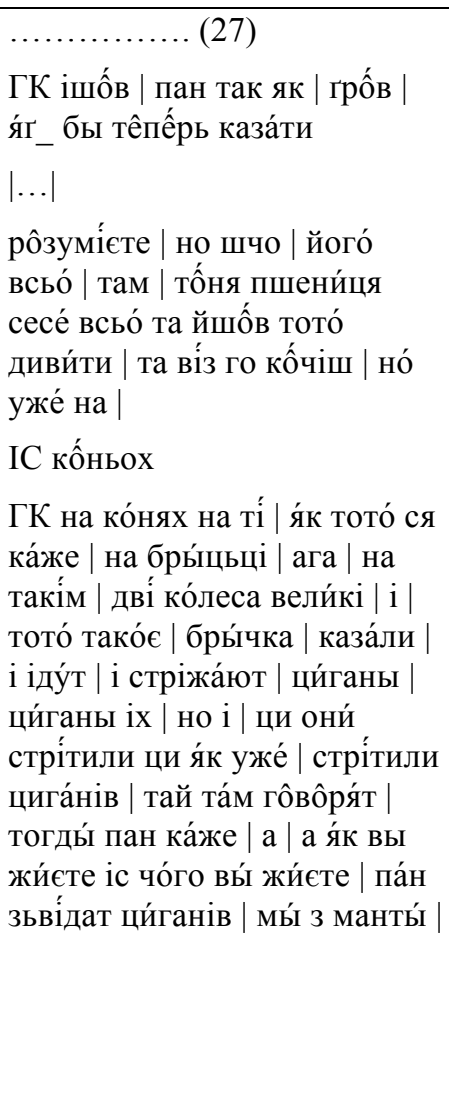 & $\begin{array}{l}\text { HK: A nobleman was riding, } \\
\text { such as a count, how would we } \\
\text { say now? } \\
\text { [Interviewer: I understand.] } \\
\text { HK: You understand? Well, so } \\
\text { that everything was his, there } \\
\text { was a large plot of land, wheat, } \\
\text { all that. And he went to look at } \\
\text { that all. And a coachman was } \\
\text { driving him. Well, on... } \\
\text { IS: Horses. } \\
\text { HK: On horses, on... what do } \\
\text { you call it... in a coach. Yes, on } \\
\text { such... two large wheels, that } \\
\text { was a coach, they called it. So } \\
\text { they were going, and they met } \\
\text { Roma. Or Roma met them. Or } \\
\text { they met Roma, or however it } \\
\text { was. And they were talking. } \\
\text { The nobleman said: how do you } \\
\text { live, how do you earn your } \\
\text { living? that's what the } \\
\text { noblemen asked the Roma. - } \\
\text { We, we live from manta. }\end{array}$ \\
\hline [22-01] & $\begin{array}{l}\text { ци́гане ка́жут мы́ з манты́ } \\
\text { жи́ємо | та яка́ тотó у ва́с } \\
\text { ма... із яко́ї манть́ | та мы́ бы } \\
\text { вам ка́же | указа́ли айбо ту́й }\end{array}$ & $\begin{array}{l}\text { The Roma say: we live from } \\
\text { manta. -- What is that manta of } \\
\text { yours, from what manta do you } \\
\text { live? -- We could tell you, they }\end{array}$ \\
\hline
\end{tabular}


Carpatho-Rusyns in Zakarpats'ka Oblast' of Ukraine

\begin{tabular}{|c|c|c|}
\hline $\begin{array}{c}\text { Recording, } \\
\text { minute }\end{array}$ & Text (22) & Translation \\
\hline & 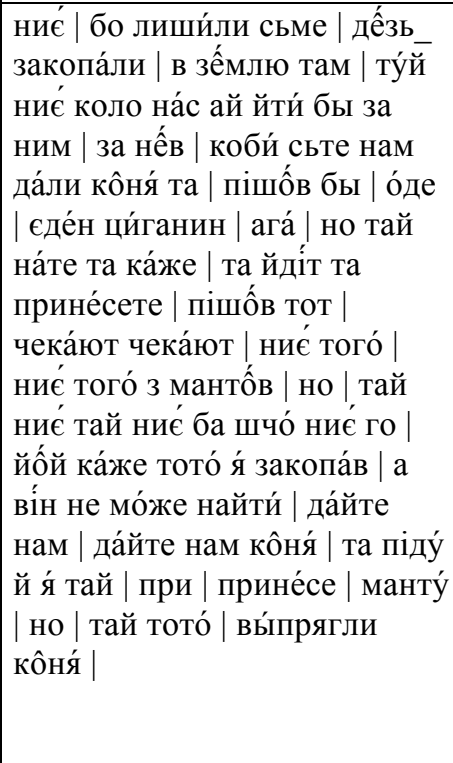 & $\begin{array}{l}\text { say, but it is not here, because } \\
\text { we left it somewhere, we buried } \\
\text { it in the ground there. It is not } \\
\text { here, we would need to go get } \\
\text { it. If you could give us a horse, } \\
\text { then one Roma could go fetch } \\
\text { it. -- OK, here is a horse, the } \\
\text { nobleman says, come and bring } \\
\text { it. So one Roma went off. They } \\
\text { were waiting and waiting, the } \\
\text { Roma did not come back and } \\
\text { did not bring the manta. He is } \\
\text { not coming, so where is he? } \\
\text { And [another Roma] says, oh, I } \\
\text { buried it, and that guy cannot } \\
\text { find it. Give us a horse so that I } \\
\text { can also go, and I will bring it. } \\
\text { Well, they unharnessed the } \\
\text { horse. }\end{array}$ \\
\hline [22-02] & 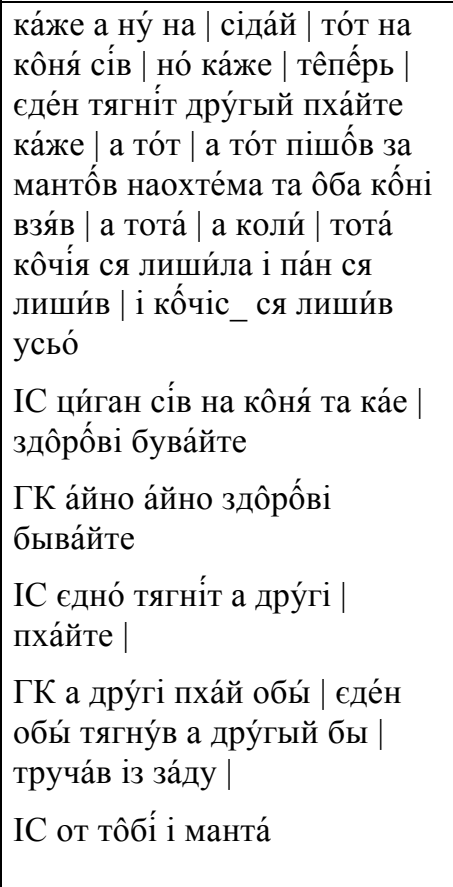 & $\begin{array}{l}\text { The nobleman says, get on the } \\
\text { horse. The Roma got on the } \\
\text { horse and says: now one pull } \\
\text { [the coach], and the other, push } \\
\text { it. And off he went, and never } \\
\text { came back, this way he went to } \\
\text { fetch the manta. They took both } \\
\text { horses. And the coach } \\
\text { remained, and the nobleman } \\
\text { remained, and his coachman } \\
\text { remained. } \\
\text { IS: The Roma got on the horse } \\
\text { and says: fare you well... } \\
\text { HK: Yes, yes, fare you well... } \\
\text { IS: One person, pull it [the } \\
\text { coach], the other, push it. } \\
\text { HK: And the other, push it. So } \\
\text { that one would pull it, and the } \\
\text { other, push from behind. } \\
\text { IS: That's the manta. }\end{array}$ \\
\hline
\end{tabular}




\begin{tabular}{|c|c|c|}
\hline \multirow[t]{2}{*}{$\begin{array}{l}\text { Recording, } \\
\text { minute }\end{array}$} & Text (22) & Translation \\
\hline & $\begin{array}{l}\text { ГК но тай тоббі́ манта́ | тай } \\
\text { цига́не та́к із манты́ і жи́ют | } \\
\text { та́м о̂бманя́т та́м о̂бману́т тай } \\
\text { цига́не так жи́ют із манты́ | } \\
\text { но | шче̂́ м ся нагада́ла та } \\
\text { д[у́маю] уже́ і сесе́ | оби́ сьте } \\
\text { ма́ли }\end{array}$ & $\begin{array}{l}\text { HK: Yes, that's the manta. And } \\
\text { the Roma live from that manta. } \\
\text { They deceive here and deceive } \\
\text { there, and so they live from } \\
\text { manta. Well, and also I } \\
\text { remembered another story, and } \\
\text { I think let it be here, so that you } \\
\text { have it. }\end{array}$ \\
\hline [22-03] & 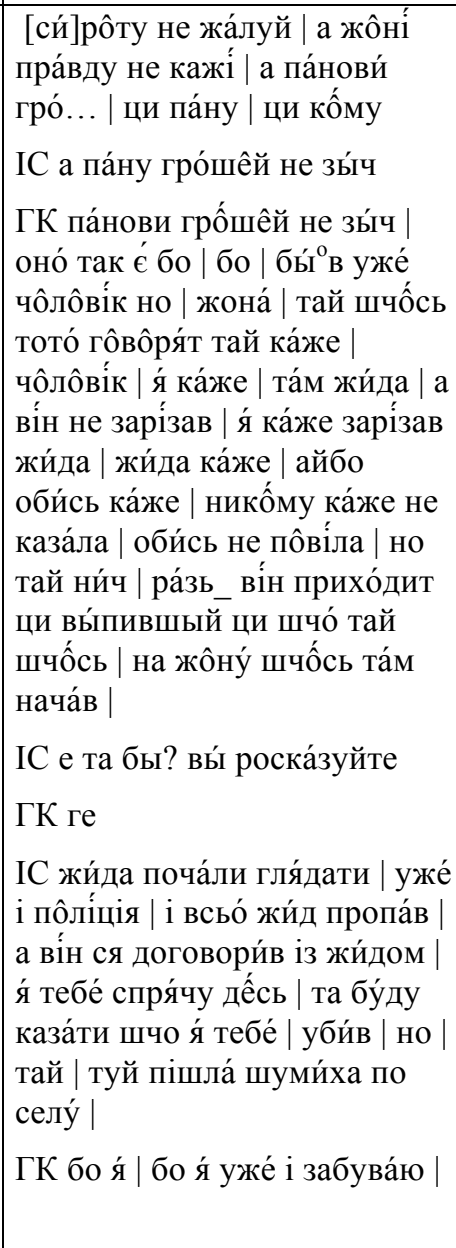 & $\begin{array}{l}\text { Don't pity an orphan, and don't } \\
\text { tell truth to your wife, and } \\
\text { money... don't lend money to a } \\
\text { nobleman? or to who? } \\
\text { IS: Don't lend money to a } \\
\text { nobleman. } \\
\text { HK: Don't lend money to a } \\
\text { nobleman, that is right, } \\
\text { because... There was a husband } \\
\text { and a wife, and they speak, and } \\
\text { the husband says: I, he says, I } \\
\text { killed a Jew. But he didn't kill } \\
\text { this Jew. He said: I killed the } \\
\text { Jew, just don't tell anybody, } \\
\text { don't tell. OK. So once he } \\
\text { comes home, either drunk or } \\
\text { what, and started saying } \\
\text { something unpleasant to his } \\
\text { wife. } \\
\text { IS: [unclear] You tell. } \\
\text { HK: What? } \\
\text { IS: People started to look for } \\
\text { the Jew, already the police } \\
\text { started searching, the Jew had } \\
\text { disappeared. And that man } \\
\text { arranged it with the Jew, I will } \\
\text { hide you somewhere, and I'll } \\
\text { say that I have killed you. So } \\
\text { there was unrest in the village. }\end{array}$ \\
\hline
\end{tabular}


Structure of a Story-Telling Performance Among

Carpatho-Rusyns in Zakarpats'ka Oblast' of Ukraine

\begin{tabular}{|c|c|c|}
\hline $\begin{array}{c}\text { Recording, } \\
\text { minute }\end{array}$ & Text (22) & Translation \\
\hline & & $\begin{array}{l}\text { HK: Because I forget things } \\
\text { sometimes. }\end{array}$ \\
\hline [22-04] & 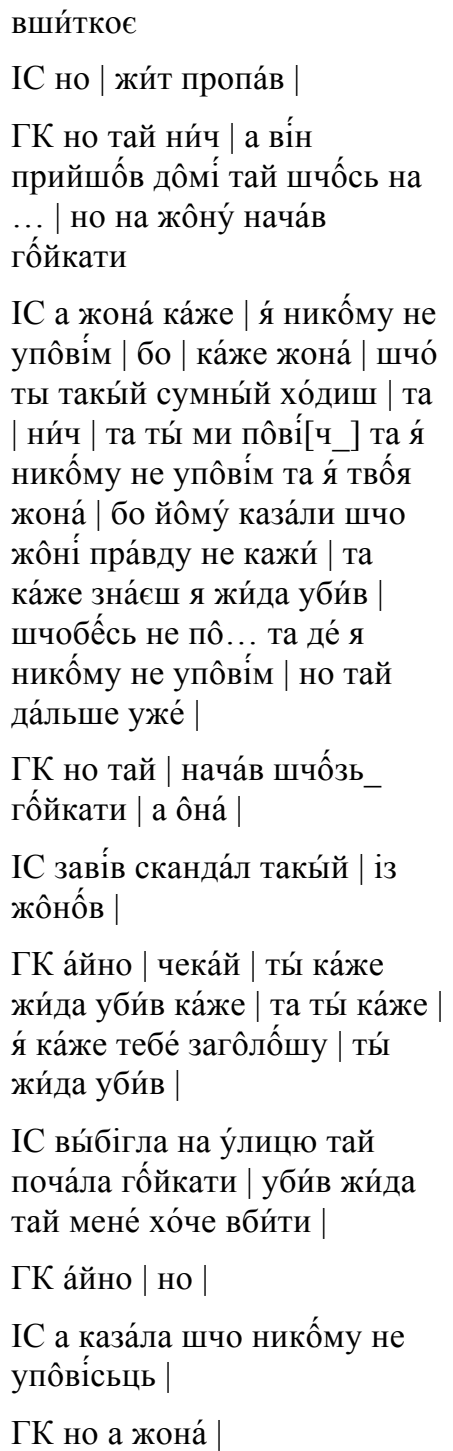 & $\begin{array}{l}\text { Everything. } \\
\text { IS: Well, the Jew disappeared. } \\
\text { HK: OK. And the man came } \\
\text { home once, and somehow he } \\
\text { started shouting at his wife. } \\
\text { IS: And the wife says: I won't } \\
\text { tell anybody. Because the wife } \\
\text { had started asking: why are you } \\
\text { so sad? -- Well, nothing. -- But } \\
\text { do tell me, I won't tell anybody } \\
\text { because I am your wife. } \\
\text { Because someone told him not } \\
\text { to tell the truth to his wife. -- } \\
\text { You know, he says, I killed a } \\
\text { Jew. Don't... -- No, no, I am } \\
\text { not telling anybody. And then... } \\
\text { HK: So he started shouting for } \\
\text { some reason, and she... } \\
\text { IS: He started an argument, } \\
\text { with his wife. } \\
\text { HK: Yes. Wait, you killed the } \\
\text { Jew, she says. You, she says, I } \\
\text { will denounce you, you killed } \\
\text { the Jew. } \\
\text { IS: She ran outside and started } \\
\text { yelling: he killed the Jew and } \\
\text { now he wants to kill me. } \\
\text { HK: Yes, yes. } \\
\text { IS: And she had told him that } \\
\text { she wouldn't tell anybody. } \\
\text { HK: And the wife... }\end{array}$ \\
\hline [22-05] & $\begin{array}{l}\text { но та за тто́ | шчо | ка́жут } \\
\text { шчо жоิні́ пра́вду не кажи́ } \\
\text { шчо она́ на не̂́i | не вы́держит }\end{array}$ & $\begin{array}{l}\text { And because of that... People } \\
\text { say, don't tell the truth to your } \\
\text { wife, because she won't be able }\end{array}$ \\
\hline
\end{tabular}




\begin{tabular}{|c|c|c|}
\hline $\begin{array}{c}\text { Recording, } \\
\text { minute }\end{array}$ & Text (22) & Translation \\
\hline & 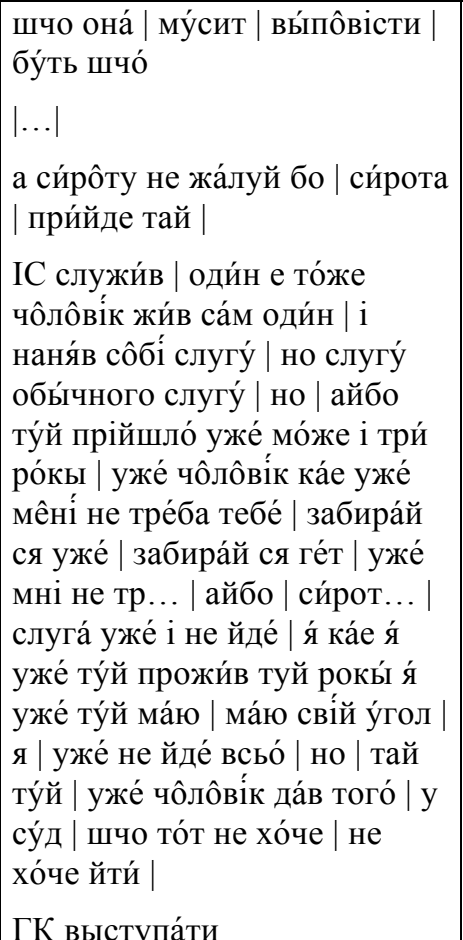 & $\begin{array}{l}\text { to hold it, she just needs to tell } \\
\text { it, whatever the circumstances. } \\
\text { [Interviewer: And why should } \\
\text { you not pity an orphan?] } \\
\text { HK: And don't pity the orphan } \\
\text { because the orphan will come } \\
\text { and... } \\
\text { IS: He served... One man lived } \\
\text { alone, and hired himself a } \\
\text { servant. A servant, a regular } \\
\text { servant. But it happened so, } \\
\text { maybe three years later... That } \\
\text { man says, I don't need you } \\
\text { anymore, go, go, I don't need... } \\
\text { But the orph... the servant } \\
\text { won't go. He says: I have lived } \\
\text { here for these years, I have my } \\
\text { own place here, I... and he is } \\
\text { not leaving. That man sued him, } \\
\text { because the servant did not } \\
\text { want to go. } \\
\text { HK. To leave. }\end{array}$ \\
\hline [22-06] & 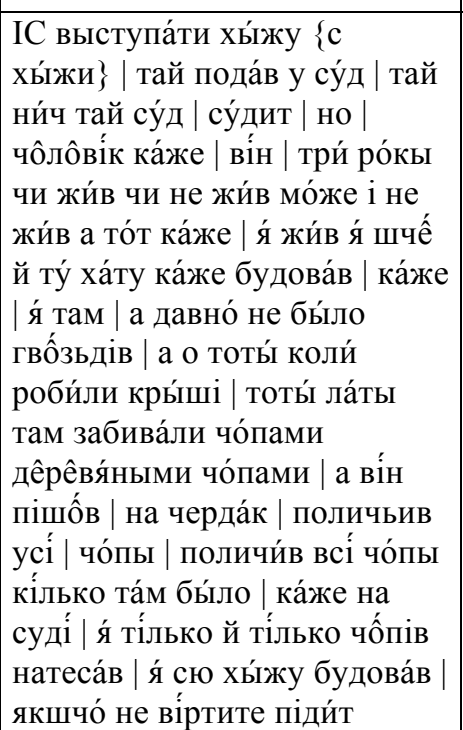 & $\begin{array}{l}\text { IS: To leave the house. So he } \\
\text { sued him. OK, there is the } \\
\text { court. The man says: he lived at } \\
\text { my place for three years, } \\
\text { whether he lived that long, } \\
\text { whether he did not. And the } \\
\text { servant says: I did live there, I } \\
\text { actually built that house. Long } \\
\text { ago there were no nails, and } \\
\text { when people made roofs, they } \\
\text { nailed these planks with } \\
\text { wooden nails. And he went to } \\
\text { the loft, and counted all the } \\
\text { wooden nails. He counted the } \\
\text { wooden nails, how many were } \\
\text { there. And in court he says: I } \\
\text { have made that many wooden } \\
\text { nails, it was me who built that }\end{array}$ \\
\hline
\end{tabular}


Structure of a Story-Telling Performance Among

Carpatho-Rusyns in Zakarpats'ka Oblast' of Ukraine

\begin{tabular}{|c|c|c|}
\hline $\begin{array}{c}\text { Recording, } \\
\text { minute }\end{array}$ & Text (22) & Translation \\
\hline & 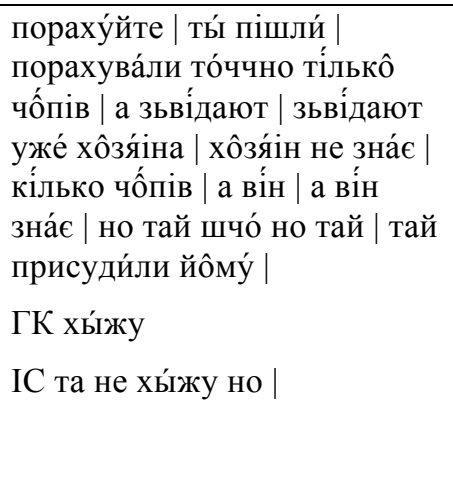 & $\begin{array}{l}\text { house, and if you don't believe } \\
\text { me then come and count. They } \\
\text { went, counted the wooden nails } \\
\text { - exactly the number he had } \\
\text { said. And when they asked the } \\
\text { master, the master did not know } \\
\text { how many wooden nails were } \\
\text { there. So what? The court gave } \\
\text { him... } \\
\text { HK: The house. } \\
\text { IS: Not the whole house, }\end{array}$ \\
\hline [22-07] & 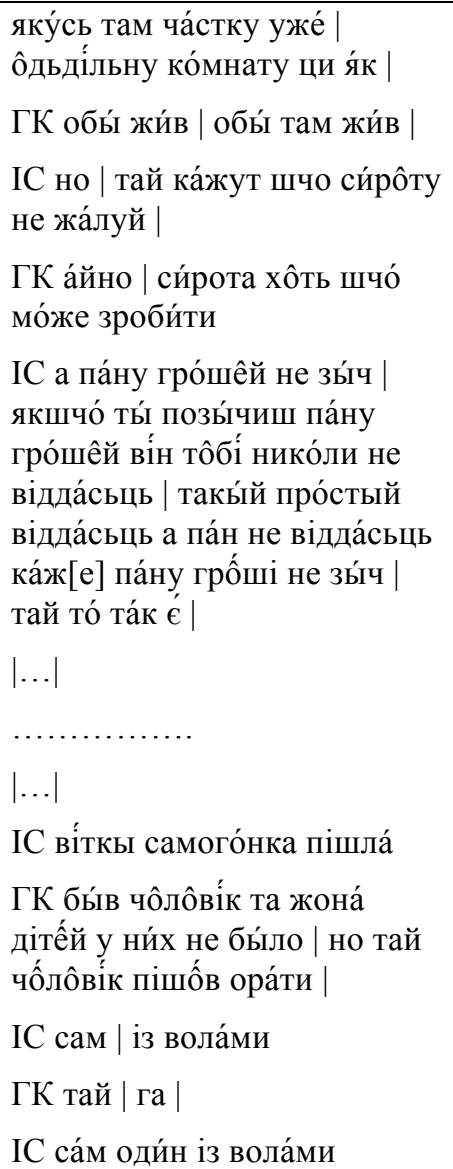 & $\begin{array}{l}\text { some part of it, maybe a room } \\
\text { or what. } \\
\text { HK: So that he could live there. } \\
\text { IS: Yes. And that is why people } \\
\text { say, don't pity an orphan. } \\
\text { HK: Yes, the orphan can do } \\
\text { whatever. } \\
\text { IS: And don't lend money to a } \\
\text { nobleman. If you lend money to } \\
\text { a nobleman, he will never pay } \\
\text { you back. A common man will } \\
\text { pay, but not a nobleman. So } \\
\text { they say, don't lend money to a } \\
\text { nobleman, and that is true. } \\
\text { [Interviewer: I also heard a } \\
\text { story once that people had to } \\
\text { take their parents to the } \\
\text { woods... Did you hear that?] } \\
\text { …................. } \\
\text { [Interviewer: Please tell me that } \\
\text { one!] } \\
\text { IS: Where moonshine came } \\
\text { from. } \\
\text { HK: There was a man and his } \\
\text { wife, they did not have children. }\end{array}$ \\
\hline
\end{tabular}




\begin{tabular}{|c|c|c|}
\hline $\begin{array}{c}\text { Recording, } \\
\text { minute }\end{array}$ & Text (22) & Translation \\
\hline & $\begin{array}{l}\text { ГК са́м із вола́ми пішо̂́в } \\
\text { ора́ти }\end{array}$ & $\begin{array}{l}\text { So the husband once went to } \\
\text { plough his field. } \\
\text { IS: On his own, with his oxen. } \\
\text { HK: On his own, with his oxen, } \\
\text { he went to plough his field. }\end{array}$ \\
\hline [22-08] & 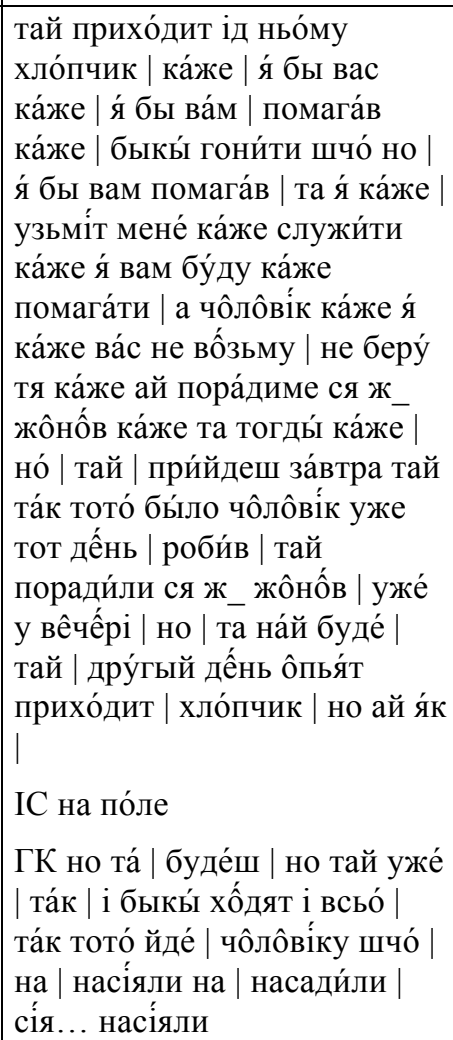 & $\begin{array}{l}\text { And a boy comes to him, and } \\
\text { says: I could help you drive the } \\
\text { oxen or whatever, I could help } \\
\text { you, and, he says, take me as } \\
\text { your servant, I will help you. } \\
\text { And the man says, I won't take } \\
\text { you, I won't, but I need to } \\
\text { consult with my wife, and then, } \\
\text { [I'll decide,] he says. Well, } \\
\text { come tomorrow, he says. And it } \\
\text { was so that the man worked that } \\
\text { day, and then he talked to his } \\
\text { wife in the evening, and she } \\
\text { was OK with it. So the next day } \\
\text { again, the boy came... } \\
\text { IS: To the field. } \\
\text { HK: Yes. You will be my } \\
\text { servant. And then... and the } \\
\text { oxen were going well, and the } \\
\text { man was lucky in everything. } \\
\text { So they planted... sowed... }\end{array}$ \\
\hline [22-09] & $\begin{array}{l}\text { зе́рна мно... ô то́го пшени́ці | } \\
\text { но | тогды́ | чоิлоิві́к ка́же но } \\
\text { та всьо́го є́ всьо́ ка́же є́ | но } \\
\text { шчо́ бдеме́ с ть́м роби́ти | } \\
\text { IC а то́т слу́жить_і слу́жит | } \\
\text { ГК а то́т слу́жи́т | а | тот } \\
\text { хло́пчик ка́же | та ни́ч ка́же }\end{array}$ & $\begin{array}{l}\text { a lot of grain, that wheat. And } \\
\text { then the man says, there is a lot } \\
\text { of everything, what will we do } \\
\text { with all that. } \\
\text { IS: And the boy keeps serving. } \\
\text { HK: And the boy keeps serving. } \\
\text { And the boy says, it is OK, }\end{array}$ \\
\hline
\end{tabular}


Structure of a Story-Telling Performance Among

Carpatho-Rusyns in Zakarpats'ka Oblast' of Ukraine

\begin{tabular}{|c|c|c|}
\hline $\begin{array}{c}\text { Recording, } \\
\text { minute }\end{array}$ & Text (22) & Translation \\
\hline & 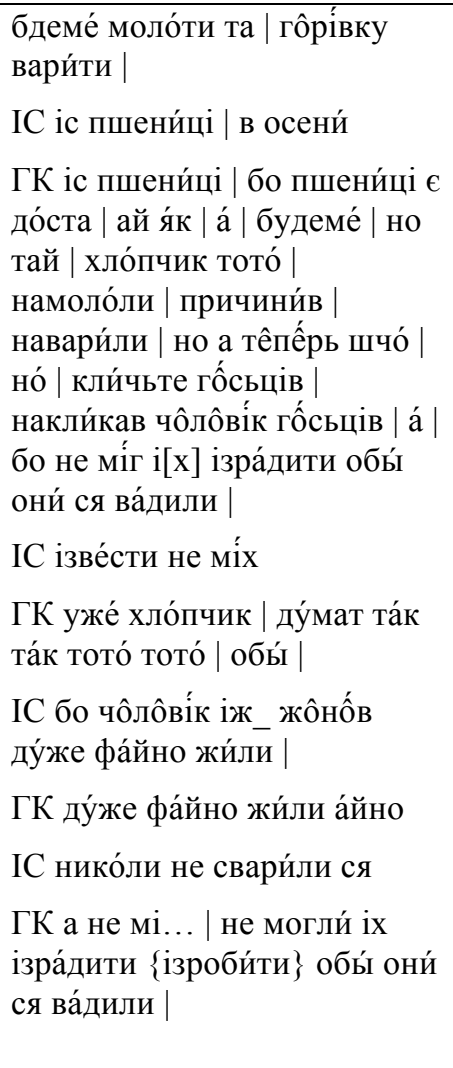 & $\begin{array}{l}\text { we'll grind it and make } \\
\text { moonshine. } \\
\text { IS: Out of the wheat, in the fall. } \\
\text { HK: Out of the wheat, because } \\
\text { there was a lot of wheat. OK, } \\
\text { we'll do that. And the boy... So } \\
\text { they ground the wheat, started } \\
\text { fermenting it, made moonshine. } \\
\text { And what now? -- Now, he } \\
\text { says, call in guests. So the man } \\
\text { called a lot of guests. Because } \\
\text { that guy could not make them } \\
\text { quarrel. } \\
\text { IS: He could not make them } \\
\text { quarrel. } \\
\text { HK: That boy. He was thinking, } \\
\text { how can I do it so that... } \\
\text { IS: Because the husband and the } \\
\text { wife lived very nicely together. } \\
\text { HK: Very nicely, yes. } \\
\text { IS: They never quarreled. } \\
\text { HK: And he couldn't... they } \\
\text { couldn't make them quarrel. }\end{array}$ \\
\hline [22-10] & $\begin{array}{l}\text { ния́к | і ту́йкы уже́ i | } \\
\text { закли́чьте ка́же го̂́сьців | но | } \\
\text { закли́кали айбо они́ фа́йно | } \\
\text { не ва́дять_ся ни́ч тото́ та́к } \\
\text { фа́йно | і пью́т | уже́ го̂́сьці і } \\
\text { го̂́ьцять_ся | i | вы́пили єди́н } \\
\text { стака́н | дру́гый стака́н | така́ } \\
\text { во́тка до́бра | } \\
\text { ІС [ка́же] ди́влят на́ ся } \\
\text { спершу́ та́к як ли́сы | } \\
\text { ГК ага́ | вы́пили єди́н | ни́ч } \\
\text { ишче́́ | дру́гый вы́пили | та } \\
\text { уже́ такі ве̂се̂́лі та́к на ся } \\
\text { ди́влят | іва́н ка́же ги ли́сы | }\end{array}$ & $\begin{array}{l}\text { By no means. And then already, } \\
\text { he says, call in guests. So they } \\
\text { called the guests, but the guests } \\
\text { are nice, they don't argue or } \\
\text { fight. So they drink, the guests } \\
\text { drink. They drunk one glass, } \\
\text { another glass, the vodka is so } \\
\text { good. } \\
\text { IS: People say, they look at } \\
\text { each other so as foxes. } \\
\text { HK: Yes. They drank one } \\
\text { [glass] - nothing. They drank } \\
\text { another glass, and they are } \\
\text { already so happy, they look at }\end{array}$ \\
\hline
\end{tabular}




\begin{tabular}{|c|c|c|}
\hline $\begin{array}{c}\text { Recording, } \\
\text { minute }\end{array}$ & Text (22) & Translation \\
\hline & $\begin{array}{l}\text { IC уже́ як во́́вци ди́влят оди́н } \\
\text { на дру́гого } \\
\text { ГК а тре́тый вы́пили | уже́ } \\
\text { ту́й нача́ли | єди́н на дру́гого } \\
\text { | го̂̆йкати | á | ты́ мні́ та́м } \\
\text { переора́в ты́ мні пока... } \\
\text { перекоси́в ты́ тото́ мні́ уже́ } \\
\text { зроби́в | уже́ нача́ли єди́н на } \\
\text { дру́гого | сусі́ди | но й ту́й } \\
\text { поналива́ли погари́ | і | она́ | } \\
\text { жона́ шчо̂́сь прине́сла | }\end{array}$ & $\begin{array}{l}\text { each other, as Ivan says, as } \\
\text { foxes. } \\
\text { IS: They already look like } \\
\text { wolves at each other. } \\
\text { HK: And when they drank the } \\
\text { third glass, they started yelling } \\
\text { at each other: you took my land } \\
\text { and ploughed it, you mowed my } \\
\text { hay, you did that to me... they } \\
\text { started yelling at each other, the } \\
\text { neighbors. And they poured } \\
\text { vodka in their glasses again, } \\
\text { and the wife brought } \\
\text { something... }\end{array}$ \\
\hline$[22-11]$ & 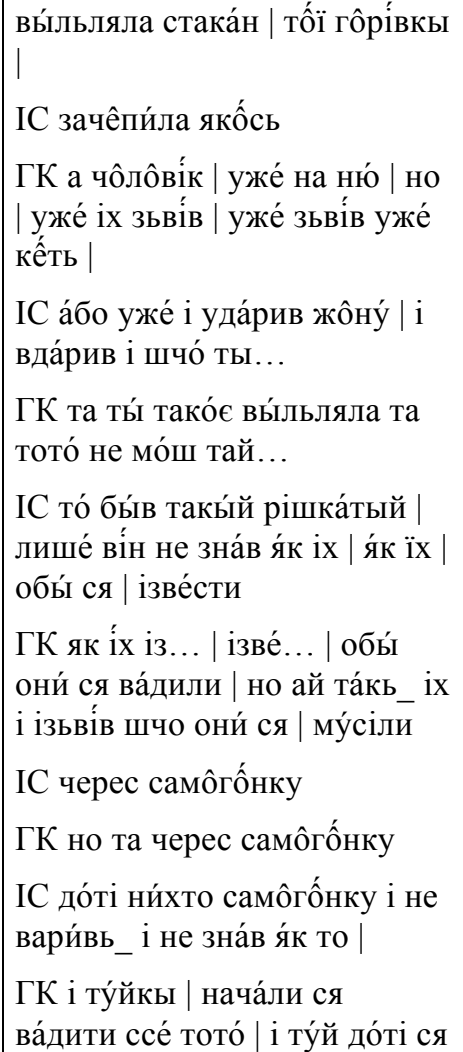 & $\begin{array}{l}\text { She turned over a glass of that } \\
\text { vodka. } \\
\text { IS: She offended him somehow. } \\
\text { HK: And the husband already at } \\
\text { her... he [the devil] already } \\
\text { made them quarrel. } \\
\text { IS: And he even hit his wife, he } \\
\text { hit her, why did you... } \\
\text { HK: Why did you turn that } \\
\text { over, it is a bad thing to do... } \\
\text { IS: That was he, the horned one, } \\
\text { he just did not know how to ... } \\
\text { how to make them quarrel... } \\
\text { HK: How to make them quarrel, } \\
\text { so that they would quarrel. And } \\
\text { this way he made them quarrel, } \\
\text { so that they had to... } \\
\text { IS: Because of the moonshine. } \\
\text { HK: Yes, because of the } \\
\text { moonshine. }\end{array}$ \\
\hline
\end{tabular}


Structure of a Story-Telling Performance Among

Carpatho-Rusyns in Zakarpats'ka Oblast' of Ukraine

\begin{tabular}{|c|c|c|}
\hline $\begin{array}{c}\text { Recording, } \\
\text { minute }\end{array}$ & Text (22) & Translation \\
\hline & $\begin{array}{l}\text { | і ва́дили | шчо пак я́к ото́ | } \\
\text { єнны́ пішли гі ли́сы єнны́ гі } \\
\text { во̂́вци | а тре́́ті | переба́ште } \\
\text { та́к як сви́ні | усю́ды ся | }\end{array}$ & $\begin{array}{l}\text { IS: Before that, no one made } \\
\text { moonshine, and people did not } \\
\text { know how. } \\
\text { HK: And here they started to } \\
\text { argue, about this and that, and } \\
\text { argued until... some went as } \\
\text { foxes, some as wolves, and } \\
\text { some, forgive the rude word, as } \\
\text { pigs. All over the place, }\end{array}$ \\
\hline$[22-12]$ & $\begin{array}{l}\text { кача́ли поิ боิлоิтоิви | і ни́ч не } \\
\text { тями́ли | через | через во̂́тку | } \\
\text { но а́йбо ци та́к оно́ є́ | ге́ | но } \\
\text { а ну́ ж | а ци́ пью́т у то̂́му у } \\
\text { аме́[риці] }\end{array}$ & $\begin{array}{l}\text { they were rolling in the mud } \\
\text { and did not remember anything. } \\
\text { Because of the vodka. Yes. } \\
\text { Ain't it so? See. And tell me, do } \\
\text { they drink in that, in America? }\end{array}$ \\
\hline
\end{tabular}

\section{NOTES}

1 See an overview of works on discourse, performance, and culture, including folklore, in Scherer [1990: $4 \mathrm{ff}$.], and on linguistic ethnopoetics in Friedrich [2006: $214 \mathrm{ff}$.]

2 See Hymes [1975, 1981, and 2003, $370 \mathrm{ff}$.] for comparison of Alter's findings on Biblical Hebrew narrative and Hymes' own findings on the Chinook myth narrative, and 2003, 435-9 for the list of work on verse analysis for a number of cultures; [Sherzer 1987, 1990, 2001]; [Tedlock 1983], [Urban 1988, 1991], [Webster 2008, 2008a], [Rumsey and Niles 2011], etc.

3 See Lord's explanation of the relation between the performance and the (epic) song's text which emphasizes the role of performance as creation and performer as creator: "Each performance is the specific song, and at the same time it is the generic song. The song we are listening to is 'the song'; for each performance is more than a performance; it is a re-creation" [Lord 1960: 101]; "a song has no 'author' but a multiplicity of authors, each singing being a creation, each singing having its own single 'author"' [ibid., 102].

4 Only a few researchers of folklore given any attention to the textual features of the feedback provided to the story-teller by the audience or to the story-teller's response. Toelken describes listener's reaction to the performer as crucial to the style of performance: "the audience plays a central role in the narrative style" ([Toelken 1976: 155]; see also Toelken [2003: 135-136 and ff.]). For East European folklore that phenomenon has not been well documented. Dégh [1989: 114] notes that while recording Hungarian folklore in the village of Kakasd, she could record only one text that included both the story-teller's and 
the listeners' contributions. She lists the types of listeners' comments (including: spontaneous exclamations, commentary, connecting of individual experience, praise for the narrator, impatience, etc. - [ibid., p. 119]), but does not indicate how the narrator reacts, except stating that he answers all questions and "sees encouragement in every commentary, even if it is derisive or expresses doubt" [ibid.] Dégh [1995 (1976)] described the context of an in-house session and the reaction of two performers, husband and wife, to each other's words while the wife was telling belief legends, and the husband, jokes. (The actual event took place in the US, but the performers were Hungarian immigrants.)

5 I am deeply thankful to Anna Ivanivna Zavadiak, teacher at the Novoselytsia high school, and her husband Ivan Iurievych Zavadiak, principal of the same school, who have been helping me since 1986 in so many ways, from introducing me to my informants to helping me afterwards with understand the language and culture behind certain places in the recording I could not understand myself. I am thankful to HK and IS for letting me be a part of the current story-telling session. I am thankful to all other inhabitants of Novoselytsia who spend their precious time with me, telling me their stories, allowing me an insight into their world.

6 In the text, the notation refers to the minutes in the transcript in Appendix. There are two consecutive recordings transcribed in the Appendix: recording $\# 21$, containing the first part of the session, and recording \#22, containing the part that took place at the meal table. If the notation reads 21$1: 35$, the two digits before the dash indicate the recording number, the digits after the dash - the time in hours and minutes in the recording; e.g. 21-1:35 denotes the recording \#21, minute 1:35 (i.e., $1 \mathrm{hr}$. $35 \mathrm{~min}$.) In the text, recording numbers were mostly omitted and only numbers of minutes indicated; if the notation reads $1: 15$ or 18 , the numbers denote minutes. The minutes from 1:04 to 2:05 belong to the recording \#21, while the minutes from 00 to 22 belong to the recording \#22. Thus, to find, e.g., 1:22 one should find in the Appendix the transcript of record \#21 and in it, minute 1:22; to find 03 one should find the transcript of the record \#22 and in it, minute 03 .

7 See Hymes [1975: $68 \mathrm{ff}$.], where he distinguishes between the role of a narrator as "performer of a narrative" and as "collaborator in inquiry, to whom the narrative is also partly an object".

8 I distinguish here, in terms of Hymes [1975: 14ff], between three dimensions of competence in a tradition: the ability to report (tell about), to interpret (explain), and to perform; see also endnote 7.

9 Story titles can play an important role in folklore; [cf. Hymes 1981: 263-272] on the myth and story titles. It seems not to be so for Rusyn storytelling, but more research will be needed to explore this hypothesis.

10 On the role of framing devices in folk poetry and myth see Webster [2008: $448 \mathrm{ff}$.]. Here the devices are not as sophisticated as the ones he studied, but they certainly play a role in the organization of narrative.

11 Hymes [2003: 380 and elsewhere] states that in Native American myths and oral prose narratives, "initial words and phrases, such as particles 


\section{Structure of a Story-Telling Performance Among Carpatho-Rusyns in Zakarpats'ka Oblast' of Ukraine}

translatable as 'now,' 'then,' 'so,' 'well,'” are used to divide the speech into verses which are "'measured,' rather than metrical." He researches the rules of composition and grouping of these verses into larger units he calls stanzas in different Native American traditions as well as in English language narrative [Hymes 2003: 102, 305]. Applying these methods to the prose text of the performance from Novoselytsia will be a promising topic for future research.

12 In epics, formulae in strict sense are units which are rhythmical, long, and carry lexical meaning; according to Parry's definition, a formula is "a group of words regularly used under the same metrical conditions to express a given essential idea" [1971: 272]. Foley and Gejin [2012: 404] call formulae " "large words,' which may be a colon, a line, or multiple lines in length." Regarding the content, formulae vary from noun-epithet phrases to descriptions of whole situations. Formulae are flexible (words inside a formula may vary if rhythmic requirements are satisfied). They are also stackable, e.g., a noun-epithet phrase can be put in a subject position in a formula several sentences long and denoting a standard action, as saddling one's horse. The functions of formulae in the performance are different for the performer and the audience. The performer uses formulae since they allow him/her an opportunity to think, while rhythmically and meaningfully carrying on the performance. The audience enjoys the style and the suspense while the formula describes at length something that could have been just named. At the same time, formulae can organize the performance on the macro-level, e.g., forewarn listeners about specific turns in the plot, as in the case of a formula describing a character saddling his horse points to a coming battle. Formulae also can carry the function of organizing the discourse on the micro-level, e.g., introducing a character's speech, which serves as a type of quotation marks, etc. In this case, they do not have to be lengthy or rich in content. In Homeric Greek, "[t]he small phrase $\dot{\alpha} \lambda \lambda^{\prime}$ ’ $\gamma \varepsilon \varepsilon$ [lit. 'but come, go' - author's note], which occurs 149 times in the Homeric poems, regularly serves two idiomatic purposes: (1) it divides one section of a speech from another, preparing the listener or reader for a change of focus; and (2) it leads to a command or prayer" [Foley, Gejin 2012: 412]. At least three of the functions mentioned above, i.e., providing the performer time to think, creating suspense for the audience, and organizing the performance on the micro-level, are seemingly common functions for both the formulae in oral poetry and the discourse particles, or clusters thereof, in the story-telling performance in Novoselytsia.

13 On the role of repetition, both "exact repetition" and "near repetition" in folkloric texts, see Webster [2008a: $443 \mathrm{ff}$.], where the history of the research on repetition is traced starting from Jakobson 1960. On the "near repetition," or pleonasm in South Slavic epics, Foley [1996: 21] comments: "this rhetorical and tectonic figure involves partial or complete repetition of a phrase from the preceding line [...] None of these continuations is syntactically necessary; rather each one of them glosses what precedes with what amounts to an optional enrichment of the main thought." We find a similar situation in this story-telling session, if we think in terms of phrases, not lines. 
14 That would seem the most probable explanation. Formulaic beginnings and endings in a number of other traditions have been described as characteristical of those prose narratives that are perceived as distinctly fictional, not true; see Bascom [1965: 6] and Tedlock [1983: 164].

15 Tedlock [1983: 165] notices a similar device in explanatory myths of the Zuni and states that a conclusion drawn from a myth, if true, serves as an argument proving the truthfulness of the whole myth: "[e]xplanatory elements, [...] since they refer to real conditions, lend an air of reality to the stories that lead to them. This is paralogism, a literary device described by Aristotle: "Just because we know the truth of the consequent, we are in our own minds led on to the erroneous inference of the truth of the antecedent." Faulty logic it may be, but Aristotle approved of it as a verisimilitudinal device."

16 This is a well-described practice for legends; see Bennett [1989: 305 ff.].

17 See Tedlock [1983: 175].

18 The bulk of Western Ukrainian and Rusyn collection of folk tales and stories (Hnatiuk [1897, 1898, 1900], Chubinskii [1872-78], Rozdol's'kyi [1899, 1900], etc.) were dictated and written down by hand, before the advent of recording technology, which totally precluded the recording of the communicative event as a whole, though some ethnographers were very attentive to linguistic features, namely Hnatiuk. The story collection in the appendix to Pan'kevych [1938] contains a number of transcripts of sound recordings, along with hand-written texts that constitute the majority of this collection, but the transcriptions represent distinct stories. Collections of tales and stories from the second half of the $20^{\text {th }} \mathrm{c}$., mostly published as entertainment, also contain only single stories, retold in standard Rusyn [Hyriak 1965] or Ukrainian, sometimes with certain dialectal features, e.g., Khlanta [1989] and Lintur [1979, 1984], and not performance sessions. In the Ukrainian scholarship, such newest collections as Britsyna and Golovakha [2004] contain transcriptions, but not of whole performances, though the context of each story is well documented.

19 See similar conclusions about traditional Ukrainian folklore in Golovakha [2006], based on her fieldwork in Central Ukraine described in Britsyna and Golovakha [2004].

20 On $01.01 .2015,62,9 \%$ of Transcarpathian population lived in villages. In 2014, the natural increase in the rural part of Transcapathia was the highest in Ukraine, +2401 persons (to compare, only in one other region, the Rivne region, there was a natural increase in rural area, 911 persons, and in all other regions of Ukraine, there was natural decline in the rural population); in urban areas, Transcarpathia had the second largest natural increase of population, (after the Rivne region.). [Data from: State statistics of Ukraine, http://database.ukrcensus.gov.ua/PXWEB2007/ukr/publ_new1/2015/zb_nas_14. pdf, accessed August 26, 2015]

21 On the history of editing practices of prose folklore in Ukraine see Britsyna [2006: $58 \mathrm{ff}$. and passim]. 


\section{Structure of a Story-Telling Performance Among Carpatho-Rusyns in Zakarpats'ka Oblast' of Ukraine}

22 Notes on transcription: the text is in Rusyn; however, several issues are presented differently from the standard Rusyn orthography in order to preserve dialectal features: the difference between the open and closed $o$ and $e$ is marked (the letters $\hat{o}$ and $\hat{e}$ are used for the closed sounds); words such as $\partial \hat{e} \mu b$ 'day' are spelled with a closed $\hat{e}$ rather than with $u$, for example. In addition, stress marks are indicated, and there is no punctuation, except for the sign $\mid$ which denotes a pause. The sign .... denotes a place in the recording I was unable to decipher.

23 The number in the first column, e.g., \#21-1:04, consists of: the number of the recording (21), and the time in the recording (1 hr $04 \mathrm{~min}$ ), see endnote 6 .

24 In the translation, square brackets [] around a word or a part of a word indicate that this word as such is not present in transcription, but it is implied and in translation it needs to be added for adequate understanding of the text.

25 The sign $|. .$.$| in transcription indicates the interviewer's words. They$ are not transcribed, but in the Translation column, their English translation is given in square brackets: [].

26 The notation \{\} presents corrections: if an informant apparently made a speech error, I give their exact words, and then the correct version in \{\} .

27 The sign ............... indicates an interruption in the recording, where the recording was stopped and later resumed, so a chunk of conversation is missing from the recording.

\section{BIBLIOGRAPHY}

Adamec, Přemysl. 1966. Адамец, Пржемысл. “Порядок слов в современном русском языке" [Word Order in Contemporary Russian Language]. Rosparvy Československé Akademie Věd, Řada společenských věd, 76, Prague: Academia.

Bascom, W. 1965. "The Forms of Folklore: Prose Narratives." The Journal of American Folklore, 78(307): 3-20.

Bauman, Richard. 1986. Story, Performance, and Event: Contextual Studies of Oral Narrative. Cambridge [Cambridgeshire]: Cambridge University Press.

Bauman, Richard. 1992. Folklore, Cultural Performances, and Popular Entertainments: a Communications-Centered Handbook. New York: Oxford University Press.

Bauman, Richard. 2004. A World of Others' Words. Malden, MA: Blackwell.

Bennett, G. 1989. “'Belief Stories': The Forgotten Genre." Western Folklore, 48(4): 289-311.

Ben-Amos, Dan, ed. 1976. Folklore Genres. Austin: University of Texas Press.

Britsyna, O. IU, and Inna Golovakha. 2004. Бріцина, О. Ю., Головаха, I. Прозовий фольклор села Плоске на Чернігівщині: тексти та розвідки [Prose folklore of the village of Ploske, Chernihiv region: Texts and research]. Київ: Інститут мистецтвознавства, фольклористики та етнології ім. М. Т. Рильського.

Britsyna, O. IU. 2006. Бріцина, О. Ю. Українська усна традиційна проза: питання текстології та виконавства [Ukrainian oral traditional prose: 
Issues of textology and performance]. Ukraïns'ka usna tradytsiīna proza: pytannia tekstolohiï ta vykonavstva. Київ: Інститут мистецтвознавства, фольклористики та етнології ім. М. Т. Рильського.

Chubinskii, P. Р. 1872-1878. Чубинский, П. П. Труды этнографическостатистической экспедиции в Западно-Русский край [Works of an ethnographic-statistical expedition to the Western Russian Region]. Тт. 17. Санкт-Петербург: Императорское русское географическое общество.

Dégh, Linda. [1976] 1995. "Symbiosis of joke and legend: A case of conversational folklore." in Narratives in Society: a Performer-Centered Study of Narration. Linda Dégh. Helsinki: Suomalainen Tiedeakatemia, 286-305.

Dégh, Linda. 1989. Folktales and Society: Story-Telling in a Hungarian Peasant Community. Blommington: Indiana University Press.

Dégh, Linda. 1995. Narratives in Society: a Performer-Centered Study of Narration. Helsinki: Suomalainen Tiedeakatemia

Dégh, Linda. 1999. "The Nature of Women's Storytelling." in Traditional Storytelling Today: An International Sourcebook. Margaret Read McDonald, et. al. Chicago: Fitzroy Dearborn Publishers, 580-586.

Foley, John Miles. 1996. "Guslar and Aoidos: Traditional Register in South Slavic and Homeric Epic." Transactions of the American Philological Association. 126: 11-41.

Foley, John Miles. 1996a. "Signs, Texts, and Oral Tradition." Journal of Folklore Research, 33(1): 21-29.

Friedrich, Paul. 1986. The Language Parallax: Linguistic Relativism and Poetic Indeterminacy. Austin: University of Texas Press.

Friedrich, Paul. 2006. "Maximizing Ethnopoetics: Fine-Tuning Anthropological Experience." in Language, Culture, and Society: Key Topics in Linguistic Anthropology. Cambridge, England: Cambridge UP. Christine Jourdan and Kevin Tuite. 207-228.

Golovakha-Hicks, Inna. 2006. "Demonology in Contemporary Ukraine: Folklore or 'Postfolklore'?” Journal of Folklore Research, 43(3): 219-240.

Hnatiuk, V. 1897. Гнатюк, В. Етнографічні материяли з Угорської Руси, I: Легенди і новелі [Ethnographic materials from the Hungarian Ruthenia, I: Legends and short stories]. Львів: Наукове товариство ім. Шевченка.

Hnatiuk, V. 1898. Гнатюк, В. Етнографічні материяли з Угорської Руси, II: Казки, байки, оповідання про історичні особи, анекдоти [Ethnographic materials from the Hungarian Ruthenia, II: Fairy tales, stories, legends about historical persons, jokes]. Львів: Наукове товариство ім. Шевченка.

Hnatiuk, V. 1900. Гнатюк, В. Етнографічні материяли з Угорської Руси, III: Західні угорсько-руські комітати. ІІ. Бач-Бодрогський комітат [Ethnographic materials from the Hungarian Ruthenia, III: Western Hungarian-Ruthenian counties. II. County of Bács-Bodrog]. Львів: Наукове товариство ім. Шевченка. 


\section{Structure of a Story-Telling Performance Among Carpatho-Rusyns in Zakarpats'ka Oblast' of Ukraine}

Hymes, Dell H. 1975. "Breakthrough into Performance." In Folklore: Performance and Communication, The Hague: Mouton, 11-74.

Hymes, Dell H. 1981. "In vain I tried to tell you”: Essays in Native American Ethnopoetics. Philadelphia: University of Pennsylvania Press.

Hymes, Dell H. 1983. Essays in the History of Linguistic Anthropology. Amsterdam: J. Benjamins, 1983.

Hymes, Dell H. 2003. Now I Know Only So Far: Essays in Ethnopoetics. Lincoln: University of Nebraska Press.

Hyriak, M. 1965. Гиряк, М. Українські народні казки Східної Словаччини [Ukrainian folk tales of Eastern Slovakia]. Пряшев:Словацьке педагог. вид-во, Відділ укр. літ-ри.

http://database.ukrcensus.gov.ua/PXWEB2007/ukr/publ_new1/2015/zb_nas_14. pdf, (consulted August 26, 2015).

Jakobson, R., and P. G. Bogatyrev. 1929 (1966). "Die Folklore als eine besondere Form des Schaffens". Selected Writings, t. IV, Slavic Epic Studies, The Hague-Paris, 1-15; same as the next item.

Jakobson, Roman and Petr Bogatyrev. 1980 [1929]. "Folklore as a Special Form of Creation," trans. by John M. O’Hara. Folklore Forum 13(1): 1-21.

Jakobson, Roman. 1960. "Concluding Statement: Linguistics and Poetics," in Style in Language, Thomas Sebeok, ed. Cambridge, MA: MIT Press, 35073.

Jourdan, Christine and Kevin Tuite. 2006. Language, Culture, and Society: Key Topics in Linguistic Anthropology. Cambridge, England: Cambridge University Press.

Khlanta, I. V. 1989. Хланта, I. В. Казки Карпат: украӥнські народні казки [Tales of the Carpathian mountains: Ukrainian folk tales]. Ужгород: Карпати.

Kiliánová, Gabriela. 1999. "Women's and Men's Storytelling: What is the Difference? Some Observations in Contemporary Slovak Storytelling Communities." ELO. Estudos de Literatura Oral 5, 99-108.

Kovtunova, I. I. 1980. Ковтунова, И.И., “Порядок слов” [Word order], в: Шведова, Н. Ю. и др., ред. Русская грамматика [Russian Grammar], т. II. Москва: АН СССР.

Lintur, P. V., and IU. D. Turianytsia. 1979. Лінтур, П. В., Туряниця, Ю. Д. Казки одного села [Tales of one village]. Ужгород: Карпати.

Lintur, P. V., V. V. Lintur, I. M. Sen'ko, and V. I. Dankanych. 1984. Лінтур, П. В., Линтур, В. В., Сенько, I. М., Даканич, В. І. Зачаровані казкою : українські народні казки Закарпаття [Spellbound by a tale: Ukrainian folk tales of Transcarpathia]. Ужгород: Карпати.

MacDonald, Margaret Read, John Holmes McDowell, Linda Dégh, and Barre Toelken. 1999. Traditional Storytelling Today: An International Sourcebook. Chicago: Fitzroy Dearborn Publishers.

Pan'kevych, Ivan. 1938. Панькевич, Іван. Украӥнські говори Підкарпатської Руси і сумежних областей [Ukrainian dialects of Subcarpathian Rus and 
adjacent regions]. Прага: Nakl. Sboru pro výzkum Slovenska a Podkarpatské Rusi; v komisi "Orbis".

Parry, Milman. 1971. The Making of Homeric Verse: The Collected Papers of

Milman Parry. Oxford: Clarendon Press.

Pugh, Stefan. 2009. The Rusyn Language: A Grammar of the Literary Standard of Slovakia with Reference to Lemko and Subcarpathian Rusyn. Muenchen: Lincom Europa.

Rampton, Ben. 2009. "Interaction Ritual and Not Just Artful Performance in Crossing and Stylization." Language in Society 38(2): 149-176.

Rozdol's'kyi, O. 1899. Роздольський, О. Галищькі народні казки [Halician folk tales]. Львів: Наукове товариство ім. Шевченка.

Rozdol's'kyi, O. 1900. Роздольський, О. Галицькі народні новели [Halician folk stories]. Львів: Наукове товариство ім. Шевченка.

Rumsey, Alan, and Don Niles. 2011. Sung Tales from the Papua New Guinea Highlands: Studies in Form, Meaning, and Sociocultural Context. Acton, A.C.T.: ANU E Press.

Sherzer, Joel. 1987. "A Discourse-Centered Approach to Language and Culture." American Anthropologist 89(2): 295-309.

Sherzer, Joel. 1990. Verbal Art in San Blas. Cambridge: Cambridge University Press.

Sherzer, Joel. 2002. Speech Play and Verbal Art. Austin: University of Texas Press.

Tedlock, Dennis. 1983. The Spoken Word and the Work of Interpretation. Philadelphia: University of Pennsylvania Press.

Toelken, Barre J. 1976. "The 'Pretty languages' [sic] of Yellowman: Genre, mode, and texture in Navajo Coyote Narratives." in Folklore Genres. Dan Ben-Amos, ed. Austin: University of Texas Press. 146-170. Reprinted from: Toelken, Barre J. 1969. “The 'Pretty language' of Yellowman: Genre, mode, and texture in Navajo Coyote narratives." Genre 2, 211-235.

Toelken, Barre. 2003. The Anguish of Snails: Native American Folklore in the West. Utah State University Press: Logan, Utah.

Urban, Greg. 1988. "The Pronominal Pragmatic of Nuclear War Discourse." Multilingua 7(1-2): 67-93.

Urban, Greg. 1991. A Discourse-Centered Approach to Culture. Austin: University of Texas Press.

Webster, Anthony K. 2008. "'To All the Former Cats and Stomps of the Navajo Nation': Performance, the Individual, and Cultural Poetic Traditions." Language in Society 37(1): 61-89.

Webster, Anthony K. 2008a. "Running Again, Roasting Again, Touching Again: On Repetition, Heightened Affective Expressivity, and the Utility of Notion of Linguaculture in Navajo and Beyond." Journal of American Folklore 121(482): 441-472.

Yokoyama, Olga. 1986. Discourse and Word Order. Amsterdam/Philadelphia: J. Benjamins. 